\title{
DESIGNING AN OPPORTUNITY FUEL WITH BIOMASS AND TIRE-DERIVED FUEL FOR COFIRING AT WILLOW ISLAND GENERATING STATION AND COFIRING SAWDUST WITH COAL AT ALBRIGHT GENERATING STATION
}

Type of Report: Final

Report Period Start Date: July 1, 2000

Report Period End Date: March 31, 2004

Principal Authors: K. Payette and D. Tillman

Date of Report Issue: June 2004

USDOE Award Number: DE-FC26-00NT40894

Name and Address of Submitting Organization:

Allegheny Energy Supply Co., LLC.

4350 Northern Pike

Monroeville PA 15146-2841 


\section{DISCLAIMER}

"This report was prepared as an account of work sponsored by an agency of the United States Government. Neither the United States Government nor any agency thereof, nor any of their employees, makes any warranty, express or implied, or assumes any legal liability of responsibility for the accuracy, completeness, or usefulness of any information, apparatus, product, or process disclosed, or represents that its use would not infringe privately owned rights. Reference herein to any specific commercial product, process, or service by trade name, trademark, manufacturer, or otherwise does not necessarily constitute or imply its endorsement, recommendation, or favoring by the United States Government or any agency thereof. The views and opinions of authors expressed herein do not necessarily state or reflect those of the United States Government or any agency thereof." 


\section{ABSTRACT}

During the period July 1, 2000 - March 31, 2004, Allegheny Energy Supply Co., LLC (Allegheny) conducted an extensive demonstration of woody biomass cofiring at its Willow Island and Albright Generating Stations. This demonstration, cofunded by USDOE and Allegheny, and supported by the Biomass Interest Group (BIG) of EPRI, evaluated the impacts of sawdust cofiring in both cyclone boilers and tangentially -fired pulverized coal boilers. The cofiring in the cyclone boiler-Willow Island Generating Station Unit \#2 - evaluated the impacts of sawdust alone, and sawdust blended with tirederived fuel. The biomass was blended with the coal on its way to the combustion system. The cofiring in the pulverized coal boiler-Albright Generating Stationevaluated the impact of cofiring on emissions of oxides of nitrogen $\left(\mathrm{NO}_{\mathrm{x}}\right)$ when the sawdust was injected separately into the furnace.

The demonstration of woody biomass cofiring involved design, construction, and testing at each site. The results addressed impacts associated with operational issues - capacity, efficiency, and operability - as well as formation and control of airborne emissions such as NOx, sulfur dioxide $\left(\mathrm{SO}_{2}\right)$, opacity, and mercury. The results of this extensive program are detailed in this report. 


\section{TABLE OF CONTENTS}

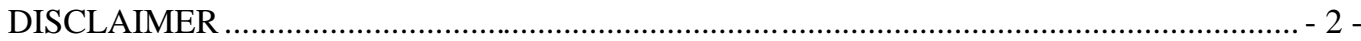

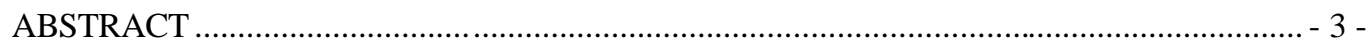

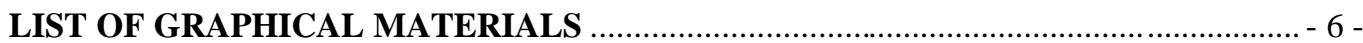

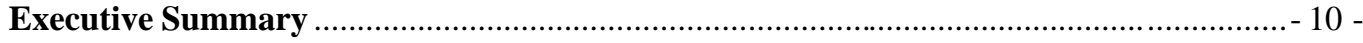

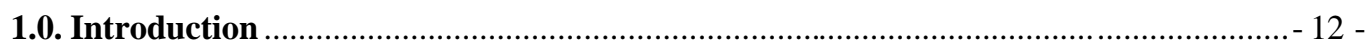

1.1. The Willow Island Demonstration......................................................................... 13 -

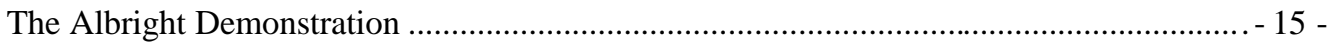

1.3. The Combined Results .................................................................... 16 -

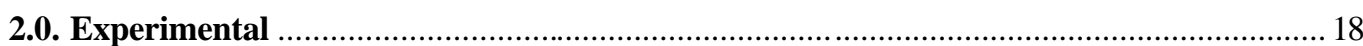

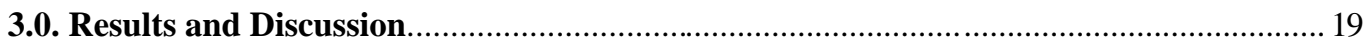

4.0. Characteristics of the Biomass Fuel and Base Coal Fuels............................................2 20

4.1. Characteristics of Base Coals Burned at the Allegheny Stations ..................................... 20

4.2. Characteristics of Sawdust Burned at Willow Island and Albright Generating

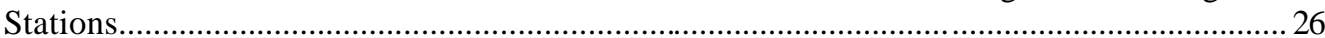

4.3. Tire-derived Fuel.................................................................................................. 34

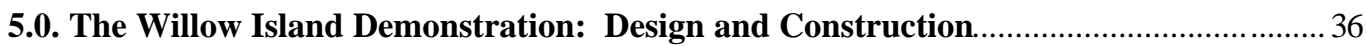

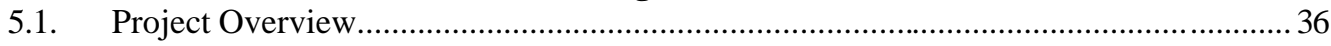

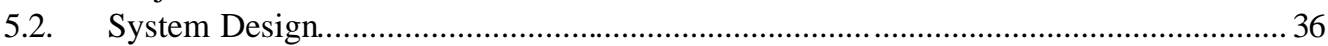

5.2.1. Combustion Modeling …..................................................................... 37

5.2.2. Process and Mechanical Engineering of the Willow Island Project................40

5.2.3. Civil, Structural, and Electrical Engineering ..........................................42

5.3. Construction of the Willow Island Cofiring Facility ............................................ 43

5.3.1. Construction Photographs ................................................................... 43

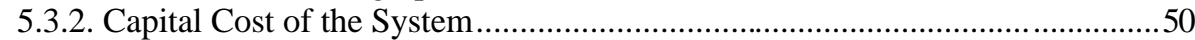

6.0. Operational and Testing Results at Willow Island Generating Station .......................5 53

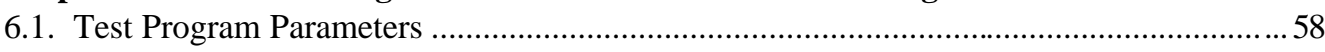

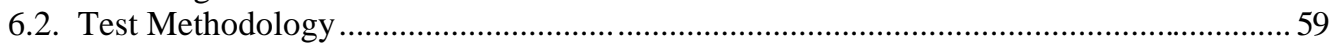

6.2.1. Test Identification and Data Gathering ...................................................60

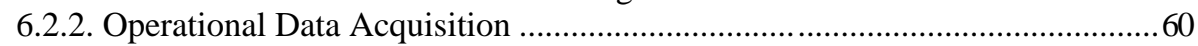

6.2.3. Environmental Data Acquisition..................................................................61

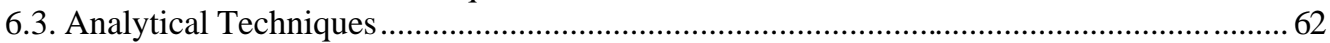

6.4. Operational Results from cofiring at Willow island ...................................................... 63

6.4.1. Impact of Cofiring on System Capacity ................................................6 63

6.4.2. Impact of Cofiring on System Efficiency .................................................64

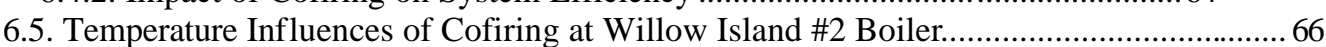

6.5.1. Flame Temperature Influences of Cofiring at Willow Island \#2 Boiler..........67

6.5.2. Furnace Exit Gas Temperature Influences of Cofiring at Willow Island \#2

Boiler.

.68

6.6. Environmental Consequences of cofiring at Willow Island \#2 Boiler ............................ 72

6.6.1. $\mathrm{SO}_{2}$ Reduction from Cofiring at Willow Island \#2 Boiler....................... 72 
6.6.2. $\mathrm{NO}_{\mathrm{x}}$ Emissions Resulting from Cofiring at Willow Island \#2 Boiler.

6.6.3. Mercury Emissions Impacts of Biomass Cofiring at Willow Island ....................... 74

6.6.4. Greenhouse Gas Emissions Impacts of Biomass Cofiring at Willow Island............ 74

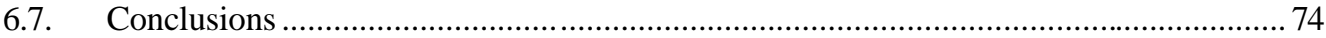

7.0. The Albright Generating Station Cofiring Design and Construction ............................ 76

7.1. Albright Generating Station Cofiring System Design .............................................. 78

7.2. Construction of the Albright Generating Station Demonstration .................................... 79

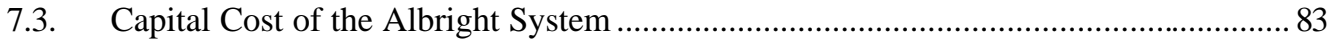

8.0. Operational Testing Results at the Albright Generating Station Demonstration ..........85

8.1. Data Acquisition and Analysis Methodology............................................................ 88

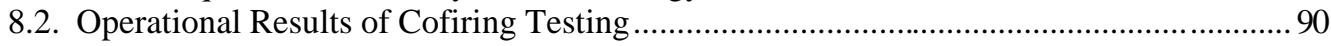

8.2.1. Operational Results - Capacit y .......................................................... 90

8.2.2. Operational Results - Efficiency ...................................................... 90

8.3. Emissions Consequences of Cofiring at Albright Generating Station............................ 95

8.4. 100 Hour Testing at Albright Generating Station..................................................100

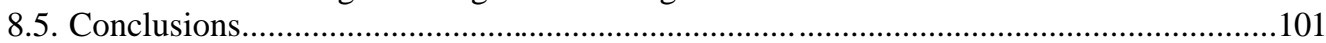

Conclusion: The Demonstrated Impacts of Cofiring at Willow Island and Albright

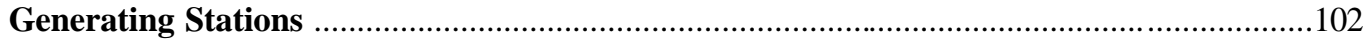

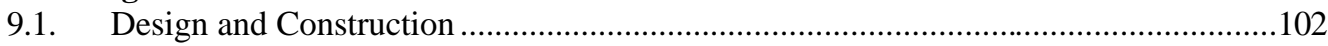

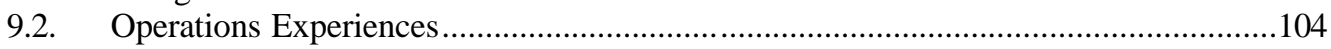

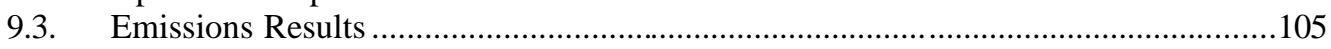

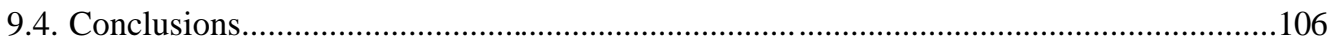

References and Bibliography (including all papers published regarding the Allegheny Cofiring Demonstrations)..... 


\section{LIST OF GRAPHICAL MATERIALS}

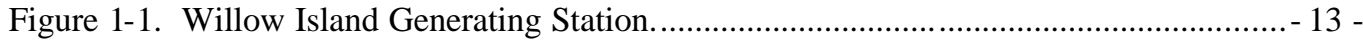

Figure 1-2. The Albright Generating Station............................................................. 16 -

Figure 41. Devolatilization Reactivity of Coal Burned at Willow Island Generating

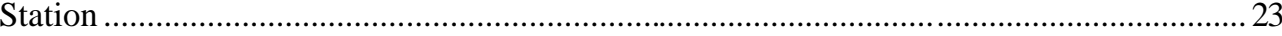

Figure 4-2. Devolatilization Reactivity of Coal Burned at Albright Generating Station. ........... 23

Figure 4-3. Char Oxidation Kinetics for Coal Burned at Willow Island Generating

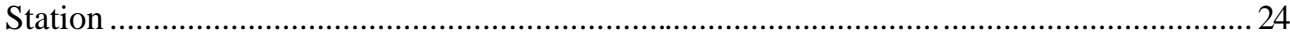

Figure 4-4. Char Oxidation Kinetics for Coal Burned at Albright Generating Station ............... 24

Figure 4-5. Nitrogen, Carbon, and Total Volatile Evolution as a Function of Temperature ........ 25

Figure 4-6. Volatile Nitrogen and Carbon Evolution Normalized to Total Volatile

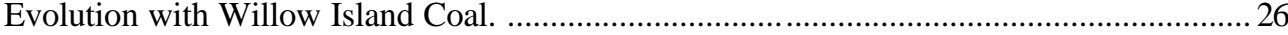

Figure 4-7. Sieve Analysis of Sawdust Obtained for the Willow Island Generating Station Demonstration. 27

Figure 48. Sieve Analysis of the Sawdust Obtained for the Willow Island Generating

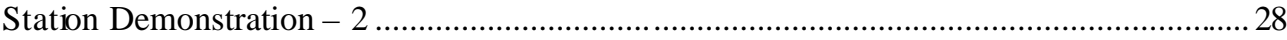

Figure 49. Low Temperature Devolatilization Kinetics for Sawdust used by Allegheny........... 31

Figure 4-10. High Temperature Devolatilization Kinetics for Sawdust used by Allegheny ........ 32

Figure 411. Char Oxidation Kinetics for Sawdust Available to Allegheny Generating

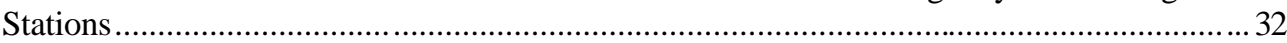

Figure 4-12. Carbon, Nitrogen, and Total Volatile Evolution from Sawdust............................ 33

Figure 413. Normalized Volatile Nitrogen and Carbon Evolution from Sawdust..................... 33

Figure 5-1. Temperature Profile of a Willow Island Cyclone Barrel Firing 100\% Coal.............. 38

Figure 5-2. Temperature Profile of a Willow Island cyclone barrel cofiring coal, and

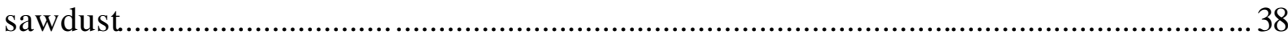

Figure 5-3. Temperature Profile of a Willow Island cyclone barrel trifiring coal, sawdust, and TDF

Figure 5-4. Temperature modeling of the furnace firing a blend of 85 percent coal/10

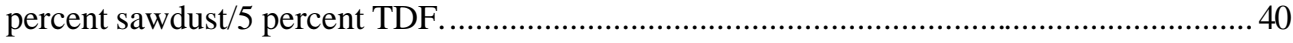

Figure 5-5. Plan View of the Willow Island Designer Fuel Cofiring System .......................... 42

Figure 5-6. Elevation View of the Willow Island Cofiring Demonstration .............................. 42

Figure 5-7. Geotechnical Soils Investigations Conducted at Willow Island in Dec. 2000.......... 43

Figure 5-8. Demolition of small structures at Willow Island, initiating construction of the

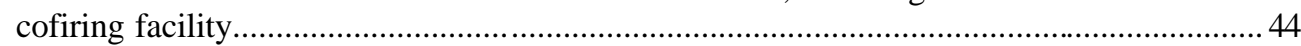


Figure 5-9. The Clean site at the beginning of construction ....................................................... 44

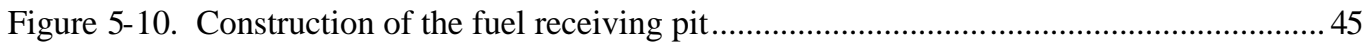

Figure 5-11. Construction of the fuel receiving pit, setting forms ................................................ 45

Figure 5-12. Laydown area for equipment to be installed including overs grinder.......................46

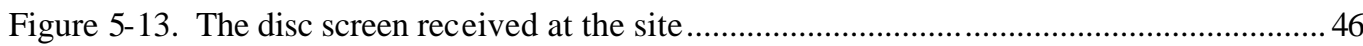

Figure 5-14. Construction of the processing facility including the disc screen, grinder,

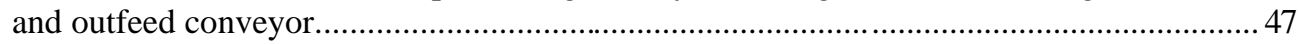

Figure 515. Construction of the processing facility including the sawdust receiving

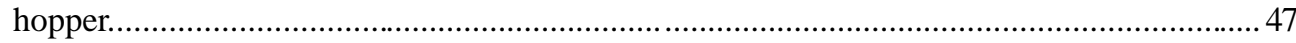

Figure 5-16. Construction of the foundation and support walls for the walking-floor bin .............. 48

Figure 5-17. Construction of the walking floor bin ................................................................. 48

Figure 5-18. Construction of the walking floor bin walls........................................................... 49

Figure 519. Completion of the walking floor bin and associated conveyor from the processing facility (under construction at extreme right) ......................................................... 49

Figure 5-20. Furnace exit gas temperature probe installed at Willow Island Generating Station as part of the cofiring demonstration.....................................................................5 50

Figure 6-1. Receiving sawdust at the Willow Island demonstration site.......................................53

Figure 6-2. The sawdust receiving hopper and door. Note the vacuum system at the far right of the structure. This facilitates housekeeping and discharges captured sawdust in the receiving hopper.

Figure 6-3. The plexiglass and rubber bumper structure at the sawdust receiving hopper,

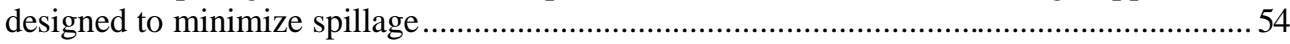

Figure 6-4. The disc screen and overs grinder discharge to the outfeed conveyor.........................55

Figure 6-5. The disc screen installed at Willow Island Generating Station.................................... 55

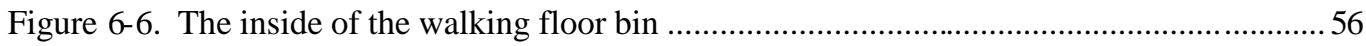

Figure 6-7. The walking floor bin receiving sawdust fromthe processing facility ........................56

Figure 6-8. The discharge of the twin auger conveyor to the metering weigh belt

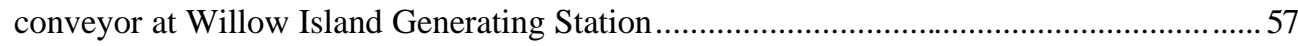

Figure 69. The discharge chute feeding sawdust onto the main conveyor at Willow

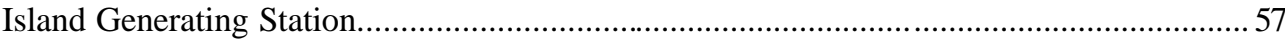

Figure 6-10. A load of sawdust being delivered to Willow Island Generating Station..................58

Figure 6-11. Comparison of $\mathrm{NO}_{\mathrm{x}}$ Reported by the CEMS, and $\mathrm{NO}_{\mathrm{x}}$ Reported, and

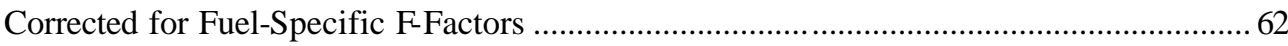

Figure 6-12. The Influence of Sawdust Cofiring on Fuel Feeding Capacity................................ 64

Figure 6-13. Schematic for heat and material balance calculations employed at Willow Island Generating Station demonstration 
Figure 6-14. The influence of cofiring sawdust on furnace exit gas temperature 69

Figure 6-15. The influence of cofiring on FEGT (English units) ............................................... 70

Figure 6-16. The influence of cofiring on main steam temperatures $\left({ }^{\circ} \mathrm{C}\right)$..................................... 71

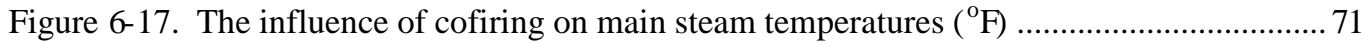

Figure 616. $\mathrm{SO}_{2}$ Emissions as a Function of Sawdust Cofiring at Willow Island \#2

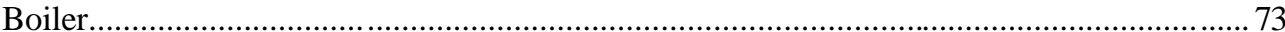

Figure 7-1. The Seward Generating Station demonstration under construction............................ 76

Figure 7-2. Ground view of the Seward Demonstration under construction, featuring the walking floor unloading system. Note the silo for sawdust storage in the

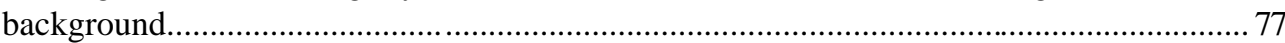

Figure 7-3. The Burner Front at Seward Generating Station with flexible piping

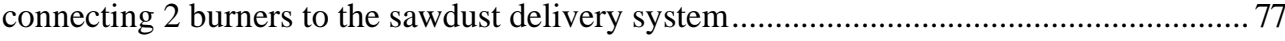

Figure 7-4. Framing the Building for the Albright Demonstration. Note the walking

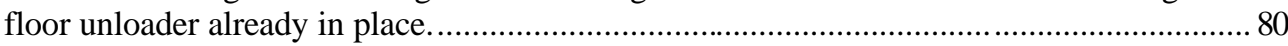

Figure 7-5. Framing the Albright building-front view featuring walking floor unloader........... 80

Figure 7-6. The Albright building partially enclosed, with the silo construction started (to

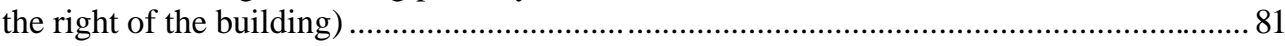

Figure 7-7. The 30 disc screen installed at the Albright demonstration. Note that the building has not been completely enclosed at this point. 81

Figure 7-8. Installing the weigh belt feeder and live bottom bin at the Albright

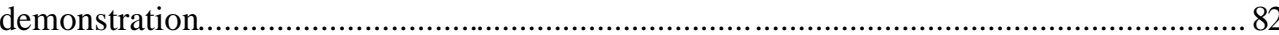

Figure 7-9. The control panel installed for the boiler operator at Albright Generating

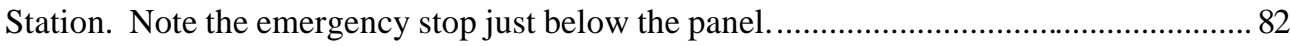

Figure 8-1. Sawdust being received at Albright Generating Station ............................................. 86

Figure 8-2. Sawdust being transported up the walking floor unloader at Albright ........................ 86

Figure 8-3. Sawdust being discharged onto the disc screen at Albright ........................................ 87

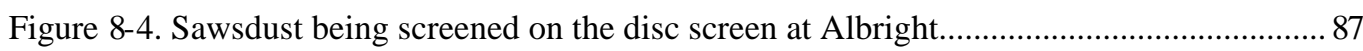

Figure 8-5. Sawdust being metered from the weigh belt to the live bottom bin at Albright ......... 88

Figure 8-6. The ribbon cutting at the dedication of the Albright cofiring demonstration .............. 88

Figure 8-7. The heat and material balance model used for analysis of Albright

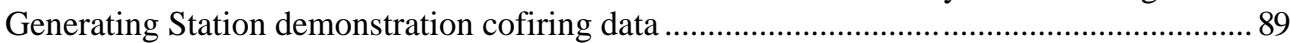

Figure 8-8. Influence of cofiring sawdust on air heater exit temperature ..................................... 91

Figure 8-9. Dry gas loss associated with biomass cofiring at Albright Generating Station ......... 92

Figure 8-10. Influence of cofiring on loss from moisture in the fuel at Albright......................... 92

Figure 8-11. Influence of hydrogen in the fuel on efficiency loss at Albright ............................ 93 
Figure 8-12. Gross and Net Water Rates as a Function of Main Steam Temperature at Albright Generating Station Boiler \#3.

Figure 8-13 . Impact of Cofiring on CO Emissions at Albright Generating Station ..................... 96

Figure 8-14. Impact of Cofiring on Opacity at Albright Generating Station............................... 97

Figure 8-15. Impact of Cofiring on $\mathrm{SO}_{2}$ Emissions at Albright Generating Station .................... 97

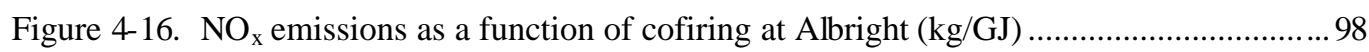

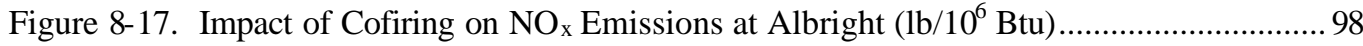

Figure 818. Comparison of observed and predicted NOx emissions at Albright based

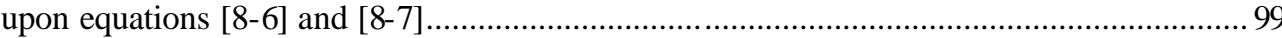

Figure 9-1. Testing a coal truck at the Albright demonstration site. .........................................103

Figure 9-2. The lack of tailgate clearance for coal trucks at the Albright demonstration ...........103 


\section{Executive Summary}

From July 1, 2000 through March 31, 2004, Allegheny Energy Supply Co., LLC demonstrated the commercial characteristics of biomass cofiring at its Willow Island Generating Station and its Albright Generating Station. These demonstrations were developed under a Cooperative Agreement with the U.S. Department of Energy National Energy Technology Laboratory and supported by the Office of Energy Efficiency and Renewable Energy, US Department of Energy. They received significant financial support from EPRI in the form of equipment installed at the Seward Generating Station, funding for testing at Albright Generating Station, and funding for additional testing and reporting. The team developed by Allegheny Energy included Foster Wheeler Development Corporation and Foster Wheeler Power Group, Inc., Cofiring Alternatives, N. Stanley Harding and Associates, Reaction Engineering International, and D.A. Tillman and Associates.

The Allegheny project won the technology transfer award from EPRI in 2003. It demonstrated that cofiring could be deployed commercially, successfully, in both cyclone and tangentially-fired pulverized coal boilers. The technology employed at Willow Island Generating Station Unit \#2, a $188 \mathrm{MW}_{\mathrm{e}}$ (net) cyclone boiler characterized by pressurized firing and equipped with a hot-side electrostatic precipitator, was blending up to 10 percent sawdust (mass basis) on the coal belt and firing this biomass in conjunction with tire-derived fuel (TDF). The technology employed at Albright Generating Station Unit \#3, a $140 \mathrm{MW}_{\mathrm{e}}$ (net) $\mathrm{T}$-fired boiler equipped with a low $\mathrm{NO}_{\mathrm{x}}$ firing system including three levels of separated overfire air (SOFA), was separate injection of up to 10 percent sawdust (mass basis) into opposite corners of the boiler in the center of the fireball.

The demonstration highlighted many of the design and construction issues including (not exhaustive) the importance of soils conditions, the numerous process equipment options and their impact on capital costs and operational considerations, and the role of plant preferences in design. Further the demonstration highlighted the capital cost/fuel cost and capital cost/operating cost trade-offs associated with cofiring. In both cases a relatively significant level of automation was incorporated into the design. The Willow Island system had a capital cost of $\$ 180 / \mathrm{kW}$ potentially supported by biomass, and a capital cost of $\$ 270 / \mathrm{kW}$ actually supported by biomass during the demonstration. The Albright demonstration included a significant amount of process equipment relocated from Seward, PA. Analysis of the data showed that this system, if constructed new, would have had a capital cost of $\$ 300 / \mathrm{kW}$ supported by biomass.

Operationally both demonstrations showed that cofiring need not impact boiler capacity applying the respective technologies to the respective types of boilers. The efficiency consequences of cofiring were minor. In the case of Willow Island, the impact of cofiring was to increase the net station heat rate (NSHR) by $3,4 \mathrm{~kJ} / \mathrm{kWh}(3.2 \mathrm{Btu} / \mathrm{kWh})$ for every percentage biomass cofired; 10 percent cofiring (mass basis) would increase the NSHR by $34 \mathrm{~kJ} / \mathrm{kWh}(32 \mathrm{Btu} / \mathrm{kWh})$. In the case of Albright, the impact of cofiring was to increase the NSHR by $4 \mathrm{~kJ} / \mathrm{kWh}(3.5 \mathrm{Btu} / \mathrm{kWh})$ for every percent biomass cofiring, or $40 \mathrm{~kJ} / \mathrm{kWh}(35 \mathrm{Btu} / \mathrm{kWh})$ when cofiring at 10 percent. 
Operationally the cofiring at Willow Island did not impact temperatures in the cyclone barrels, however it did decrease the furnace exit gas temperature (FEGT). At the same time cofiring did not decrease main steam or reheat steam temperature. Operationally cofiring at Albright was successful over a significant load range.

In both the Willow Island and Albright demonstrations, cofiring created reductions in emissions of $\mathrm{SO}_{2}$, fossil $\mathrm{CO}_{2}$, and mercury. Cofiring did not impact $\mathrm{CO}$ or opacity emissions. At Albright Generating Station, cofiring caused a significant reduction in $\mathrm{NO}_{\mathrm{x}}$ emissions. Some of that reduction came from the sawdust directly; much of that reduction came from the ability to increase the use of the SOFA system without increasing unburned carbon in the flyash. Cofiring also decreased the load on the pulverizers, potentially improving the sieve analysis of the coal and improving $\mathrm{NO}_{\mathrm{x}}$ emissions through that approach as well. $\mathrm{NO}_{\mathrm{x}}$ emissions were not reduced at Willow Island Generating Station as a function of cofiring.

The Allegheny cofiring demonstrations were successful. They demonstrated that cofiring in cyclone and T-fired boilers could be deployed commercially with certain operational benefits, few operational penalties, and with environmental improvements. The success of any such deployment, however, depends upon the plant-specific economics including differential fuel costs, the monetized value placed on SO2 and NOx emissions, and the consequences for cofiring on coal procurement. 


\subsection{Introduction}

Cofiring - the firing of two dissimilar fuels at the same time in the same boiler-has been the focus of numerous test and demonstration programs, designed to commercialize this practice applied to biomass fuels. Initial research commenced with a program funded by EPRI and the Tennessee Valley Authority (TVA), and partially supported by the Energy Efficiency and Renewable Energy (EERE) Office of the US Department of Energy (USDOE). This research program expanded to include tests and demonstrations at the Allen Fossil Plant, Colbert Fossil Plant, and Kingston Fossil Plant of TVA. Subsequently it included tests at the following installations:

- Shawville Generating Station, GPU Genco

- Seward Generating Station, GPU Genco

- Michigan City Generating Station, NIPSCO

- Bailly Generating Station, NIPSCO

Parallel test and demonstration programs were also conducted by New York State Electric and Gas (NYSEG), Southern Company at Georgia Power Co. and Alabama Power Co., and Madison Gas \& Electric Co. Prior programs had been developed by Northern States Power. Programs initiated during this period included the switchgrass cofiring testing at the Ottumwa Generating Station of Alliant Energy.

Pursuant to the commercialization of cofiring - a family of technologies useful in reducing fossil $\mathrm{CO}_{2}$ emissions through the use of $\mathrm{CO}_{2}$ neutral renewable resourcesEERE and the National Energy Technology Laboratory (NETL) solicited proposals for co-funded projects to evaluate and demonstrate various approaches to biomass fuel utilization. Project DE-FC26-00NT40894 was a response to that solicitation.

Allegheny proposed to demonstrate blending wood waste and tire-derived fuel to create a new opportunity fuel for cofiring in cyclone boilers. This proposal was to demonstrate the use of biomass-TDF blends to reduce $\mathrm{SO}_{2}$ and fossil $\mathrm{CO}_{2}$ emissions along with trace metal emissions, and to evaluate their potential for reducing $\mathrm{NO}_{\mathrm{x}}$ emissions. This demonstration, located in Willow Island, WV, has numerous unique features to significantly advance cofiring technology. The Willow Island demonstration proposed blending sawdust with TDF to create a new opportunity fuel for cofiring in a cyclone boiler. This proposal recognized that blending of two fuels does not create an energy product that is the average of those fuels; rather the blend functions as a distinct and separate new fuel.

Allegheny also proposed to move the cofiring demonstration then located at the Seward Generating Station of GPU Genco (now owned by Reliant Energy) to its Albright Generating Station and separately inject sawdust into its tangentially-fired (T-fired) boiler located at that installation. The Albright demonstration was designed to utilize a system constructed under the EPRI-USDOE Cooperative Agreement described in detail in Tillman (2001). That system was to be upgraded and installed at Albright, and fired to evaluate cofiring biomass in a boiler equipped with a separated overfire air (SOFA) 
system as a means for reducing $\mathrm{NO}_{\mathrm{x}}$ emissions along with $\mathrm{SO}_{2}$, mercury, and fossil $\mathrm{CO}_{2}$ emissions.

In both cases the demonstrations were designed to address certain issues associated with generation capacity, operability, and efficiency associated with cofiring biomass in boilers designed for firing eastern bituminous coals. Both demonstrations involved design, construction, start -up, and extensive testing of the cofiring systems. They provided comparative information concerning approaches to cofiring.

\subsection{The Willow Island Demonstration}

Allegheny Energy Supply, LLC demonstrated blending wood waste and tire-derived fuel to create a new opportunity fuel for cofiring in cyclone boilers. This project also demonstrated the use of biomass-TDF blends to reduce $\mathrm{SO}_{2}$ and fossil $\mathrm{CO}_{2}$ emissions along with trace metal emissions. The demonstration is occurring at Willow Island Generating Station Boiler\#2 (see Figure 1). This installation is a $188-\mathrm{MW}_{\mathrm{e}}$ cyclone boiler operated in a pressurized mode and equipped with a "hot side" electrostatic precipitator (ESP). This demonstration, located in Willow Island, WV, has numerous unique features to significantly advance cofiring technology.

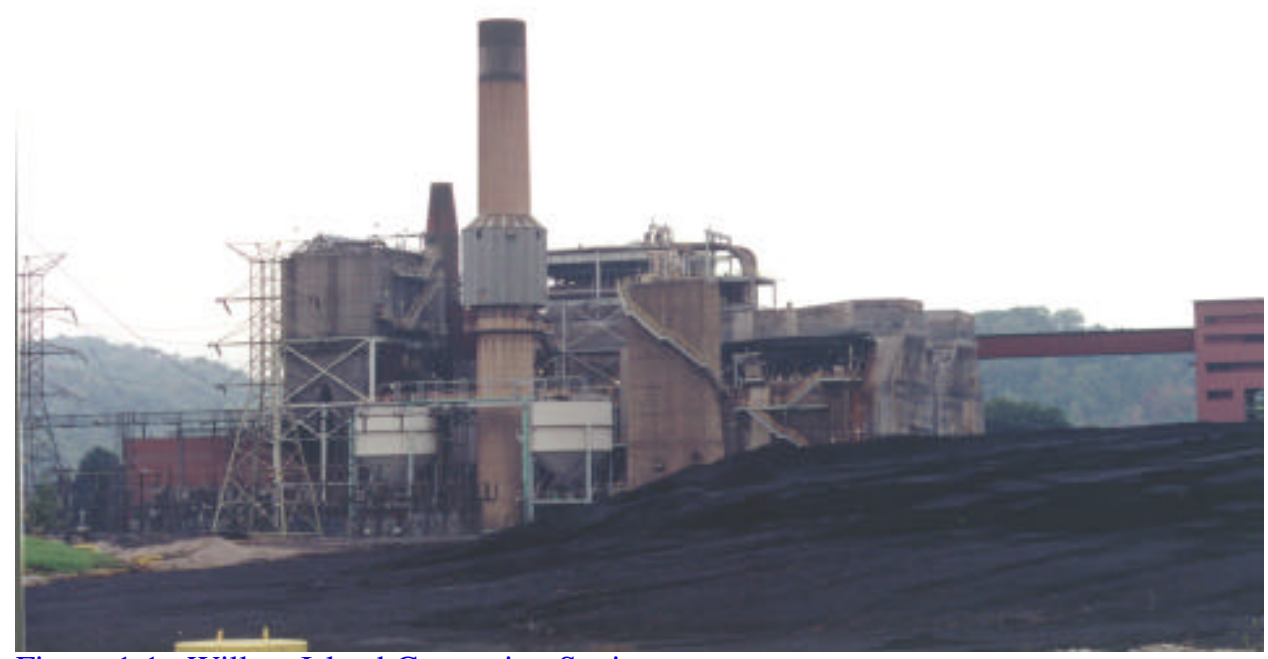

Figure 1-1. Willow Island Generating Station.

Cofiring of wood wastes with coal has been demonstrated as an effective means for using biomass in cyclone boilers; demonstrations have occurred at the Allen Fossil Plant of TVA, the Michigan City Generating Station of NIPSCO, and the Bailly Generating Station (BGS) of NIPSCO. In these demonstrations, $\mathrm{NO}_{\mathrm{x}}, \mathrm{SO}_{2}$, and fossil-based $\mathrm{CO}_{2}$ emissions reductions occurred. In each case, the volatility of the wood waste created the 
mechanism for $\mathrm{NO}_{\mathrm{x}}$ reduction, while the use of a sulfur-free fuel reduced $\mathrm{SO}_{2}$ emissions. Testing at Allen Fossil Plant, in particular, was significant because it involved several days of firing TDF, and 2 days of firing blends of sawdust and TDF. It opened the door to tri-firing (Tillman et. al., 1996a, 1997). Further, the Allen Fossil Plant testing involved the most extensive evaluation of fundamental combustion impacts in cyclone boilers (Tillman et. al., 1996a, 1996b).

Testing at BGS opened a new area of investigation: designing blends of opportunity fuels to optimize the impacts of cofiring. At BGS, urban wood waste was mixed with petroleum coke at a specified blend to optimize $\mathrm{NO}_{\mathrm{x}}$ emissions management while accomplishing the goals of fossil $\mathrm{CO}_{2}$ emissions reductions. The $\mathrm{NO}_{\mathrm{x}}$ emissions reductions at BGS were $\sim 30$ percent when firing the designed opportunity fuel blend of petroleum coke and urban wood waste (Tillman, 1999). Equations 1-1 and 1-2 reported by Tillman (1999) describe the effect, offering the promise of designer opportunity fuels.

$\mathrm{NO}_{\mathrm{x}}=0.691-0.0101\left(\% \mathrm{~W}_{\mathrm{m}}\right)-0.0098\left(\% \mathrm{PC}_{\mathrm{m}}\right)+0.0005(\mathrm{~L})+0.0255\left(\mathrm{EO}_{2}\right)$

Where $\mathrm{NO}_{\mathrm{x}}$ is reported in $\mathrm{lb} / 10^{6} \mathrm{Btu}, \% \mathrm{~W}_{\mathrm{m}}$ is percent wood on a mass basis, $\% \mathrm{PC}_{\mathrm{m}}$ is percent petroleum coke on a mass basis, $\mathrm{L}$ is load expressed as $103 \mathrm{lb} / \mathrm{hr}$ main steam, and $\mathrm{EO}_{2}$ is percent excess oxygen at the furnace exit, expressed on a total basis rather than a dry basis. The $\mathrm{r}^{2}$ for this equation is 0.70 , over 3 months of testing; the probability that the equation occurred as a random event is $5.4 \times 10^{13}$. Alternatively:

$\mathrm{NOx}=1.352-0.0162(\% \mathrm{OF})+0.0002(\% \mathrm{OF})^{2}$

Where $\% \mathrm{OF}$ is percent opportunity fuel. The $\mathrm{r}^{2}$ for this equation is 0.853 .

More significantly than the $\mathrm{NO}_{\mathrm{x}}$ reduction, however, the $\mathrm{BGS}$ testing showed that blending sawdust or urban wood waste with a high heat content opportunity fuel could provide for the use of biomass without compromising boiler efficiency or capacity. The second opportunity fuel could provide the elevated heat content while the biomass addressed the emissions issues of sulfur and ash.

Using that principle, the Willow Island demonstration successfully blended sawdust with TDF to create a new opportunity fuel for cofiring in a cyclone boiler. This demonstration evaluated the creation of a second opportunity fuel blend that has potential to maximize $\mathrm{NO}_{\mathrm{x}}$ emissions reductions from the combustion process. At the same time, $\mathrm{SO}_{2}$ emissions were reduced along with fossil $\mathrm{CO}_{2}$ emissions and heavy metal emissions. The demonstration program involved utilizing the sawdust-TDF-coal blend for maximum impact in the cyclone combustion process. It is estimated that the project could fire some 10 percent wood waste, along with about 10 percent TDF in the project.

While this demonstration involved integrating past successful programs, it provided a significant enhancement of cofiring and the use of biomass This was the first cofiring demonstration where the boiler was equipped with a "hot side" electrostatic precipitator-an ESP installed between the economizer and the air heater rather than after 
the air heater. Such "hot side" ESP's conventionally use sodium additives to improve the resistivity of the flyash and enhance its capture. Biomass, with its concentrations of potassium and sodium, could have some potential to reduce or eliminate the need for such additives. This demonstration will address that condition and, as a consequence, advance the use of cofiring in coal-fired boilers.

\section{The Albright Demonstration}

The Albright Generating Station Boiler \#3 (see Figure 2) houses a $140 \mathrm{MW}_{\mathrm{e}}$ boiler, comparable in capacity to the Willow Island boiler. It burns a similar eastern bituminous coal. Of critical importance, the Albright boiler is equipped with a low- $\mathrm{NO}_{\mathrm{x}}$ firing system including a separated overfire air system.

The Electric Power Research Institute (EPRI) developed a demonstration of sawdust cofiring in a PC boiler at the Seward Generating Station. The favorable technology potential led Allegheny to decide to relocate the cofiring demonstration to the Albright Generating Station. The relocation of the separate injection demonstration from Seward Generating Station to Albright provides opportunities to extend the knowledge base concerning cofiring - capitalizing upon the configuration of Albright Boiler \#3. Specifically cofiring has not been applied to a generating station equipped with low $\mathrm{NO}_{\mathrm{x}}$ firing separated overfire air system. In relocating the demonstration from Seward to Albright, Allegheny Energy and USDOE have capitalized upon such an opportunity.

The Albright test was based upon success at Seward Generating Station, where $\mathrm{NO}_{\mathrm{x}}$ reductions were achieved according to equation 1-3 (see Tillman, 1999):

$\mathrm{NO}_{\mathrm{x}}=0.026+0.0017(\mathrm{~L})+0.083\left(\mathrm{EO}_{2}\right)-0.899(\% \mathrm{~W} \mathrm{~m})$

This equation has an $\mathrm{r}^{2}$ of 0.93 over 15 discrete tests. While testing at the Greenidge Station of New York State Energy and Gas (NYSEG) did not report significant $\mathrm{NO}_{\mathrm{x}}$ reductions - a result which also occurred at Plant Gadsden of Alabama Power when cofiring switchgrass - the combustion conditions were sufficient to strongly suggest that $\mathrm{NO}_{\mathrm{x}}$ emissions could be reduced by cofiring sawdust into the center of the fireball.

Further, the cofiring practice could address $\mathrm{SO}_{2}$, fossil $\mathrm{CO}_{2}$, and mercury emissions while pursuing $\mathrm{NO}_{\mathrm{x}}$ reductions.

The Albright testing also capitalized upon other prior test programs where pulverized coal (PC) boilers cofired biomass with coal. It avoided the problems of blending sawdust with coal on the coal belts leading to the bunkers and pulverizers - a practice that limited the percentage of biomass that could be successfully cofired in tests at the Kingston Fossil Plant of TVA and the Shawville Generating Station of GPU Genco. Further, it capitalized upon the knowledge that the sawdust would have to be fired at substoichiometric ratios in order to achieve $\mathrm{NO}_{\mathrm{x}}$ reductions. 


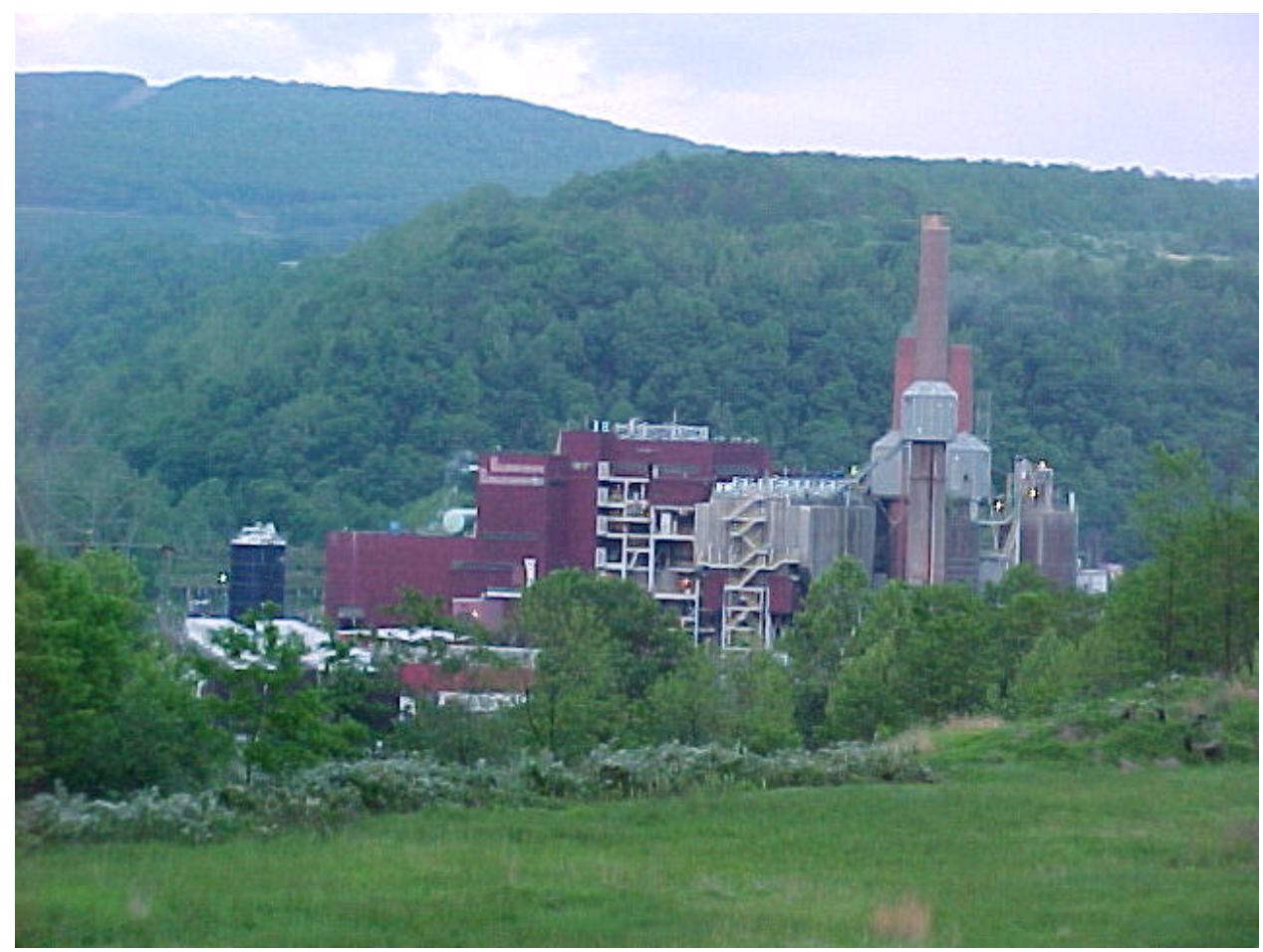

Figure 1-2. The Albright Generating Station

\subsection{The Combined Results}

The combination of the Willow Island demonstration at the cyclone boiler and the comparative data developed at the Albright demonstration in a tangentially-fired pulverized coal boiler provided definitive data concerning the emissions reduction potential of biomass cofiring. As such, these data helped define the potential, and limits, of biomass cofiring as an emissions reduction strategy. At the same time these demonstrations provided a means for evaluating biomass cofiring as a cost-effective strategy for voluntary fossil $\mathrm{CO}_{2}$ emissions reductions along with mercury reductions. Finally these projects demonstrated additional environmental benefits of cofiring.

In addressing these issues, both demonstrations addressed the following concerns:

- Process concepts for optimizing the impacts and benefits of woody biomass cofiring

- Equipment selection and system design to install woody biomass cofiring systems

- Operational issues associated with cofiring 
- Capacity, efficiency, and operability issues associated with cofiring

- Capital costs associated with future cofiring installations

Formatted: Bullets and Numbering 
2.0. Experimental

Does not apply 
3.0. Results and Discussion

Does not apply. See Chapters 4-8. 


\subsection{Characteristics of the Biomass Fuel and Base Coal Fuels}

If cofiring is used for more than Btu substitution-with the intent of replacing more expensive coal with less expensive biomass - then the technical quality of the fuels in question must be considered. Fuel properties are particularly significant when considering the use of biomass cofiring for emissions reduction (see Tillman and Harding, 2004; Johnson, Tillman, and Miller, 2003). Since biomass may or may not be less expensive than coal on a $\$ 110^{6}$ Btu basis, the fuel characteristics become of considerable importance. Beyond the issue of fuel manipulation, fuel characteristics are fundamentally important to determine the potential for cofiring without combustion problems in pulverized coal or cyclone boilers.

For these reasons, considerable attention was paid to the fuels being burned, and cofired, at the Willow Island and Albright Generating Stations. Recognizing that the performance of the fuel required considerable attention to volatility, and the evolution of volatile matter, this charact erization included both traditional approaches and advanced characterization utilizing carbon 13 nuclear magnetic resonance $\left({ }^{13} \mathrm{C} N \mathrm{NMR}\right)$ and drop tube reactor (DTR) measurements as well.

\subsection{Characteristics of Base Coals Burned at the Allegheny Stations}

Willow Island and Albright Generating Stations both burn washed Pittsburgh seam coals. Proximate and ultimate analyses of these fuels are shown in Table 4-1. These data are from testing performed by Foster Wheeler Development Corporation (FWDC) and The Energy Institute of The Pennsylvania State University (PSU).

Table 41. Proximate and Ultimate Analysis of Coals Burned at Willow Island and Albright Generating Stations

\begin{tabular}{|l|c|c|c|c|}
\hline \multicolumn{1}{|c|}{ Parameter } & \multicolumn{2}{c|}{ Willow Island Generating Station } & \multicolumn{2}{c|}{ Albright Generating Station } \\
\hline & FWDC & PSU & FWDC & PSU \\
\hline Moisture \% & 7.09 & N/A & 7.40 & N/A \\
\hline Proximate Analysis (wt \%, o.d.) & & & 13.7 \\
\hline Ash & 7.65 & 10.5 & --- & 30.6 \\
\hline Volatile Matter & --- & 34.0 & --- & 55.7 \\
\hline Fixed Carbon & --- & 55.5 & & \\
Ultimate Analysis (wt \%, o.d.) & 77.9 & 76.7 & 75.7 & 73.6 \\
\hline Carbon & 5.07 & 4.9 & 4.64 & 4.7 \\
\hline Hydrogen & 6.38 & 4.9 & 4.73 & 5.0 \\
\hline Oxygen & 1.43 & 1.4 & 1.40 & 1.4 \\
Nitrogen & 1.53 & 1.6 & 1.62 & 1.6 \\
\hline Sulfur & 7.65 & 10.5 & 11.90 & 13.7 \\
\hline Ash & & & & 30.8 \\
\hline
\end{tabular}


With the exception of ash concentration, the analyses for these coals demonstrate consistent parameters for both stations. Similarly, the mercury concentrations in these coals were $0.15 \mathrm{mg} / \mathrm{kg}$ at the Albright Generating Station and $0.18 \mathrm{mg} / \mathrm{kg}$ at the Willow Island Generating Station (Tillman, Payette, and Banfield, 2003).

Structural analyses of these coals revealed a highly aromatic fuel. The Willow Island Generating Station coal sample analyzed by PSU indicated that 70 percent of the carbon atoms were contained in aromatic structures, and that the average aromatic cluster contained 15 aromatic carbons. A fused aromatic ring structure with 15 carbon atoms has significantly more than three benzene rings per cluster, and can have four benzene rings per cluster. The coal burned at Albright Generating Station is slightly more aromatic, with 73 percent of the carbon atoms contained in aromatic structures. However the fuel has an average of 13 carbon atoms per cluster indicating a maximum of 3 benzene rings per fused aromatic structure.

Drop tube reactor measurements for the coals burned at Willow Island Generating Station and at Albright Generating Station were performed to determine the maximum volatile yield, the devolatilization kinetics, and the pathways of volatile evolution focusing upon nitrogen volatile evolution. For these tests, coal samples were ground to 140x200 mesh and then devolatilized in a drop tube reactor over a series of temperatures ranging from $600^{\circ} \mathrm{C}\left(1110^{\circ} \mathrm{F}\right)$ to $1700^{\circ} \mathrm{C}\left(3090^{\circ} \mathrm{F}\right)$. These temperatures are bulk reactor temperatures, not particle temperatures. The devolatilization was accomplished in an argon atmosphere in order to ensure the precise measurement of nitrogen volatile evolution without interaction with the carrier gas. The fuel was carefully weighed from the feeder before and after the test, to determine the total amount of fuel feed to the DTR. Likewise, the char was carefully collected and weighed from three sources: 1) the char deposited on top of the filter paper, 2) char trapped in the filter paper 3) char deposited on the probe wall. The sum of these three yields the total char collected, for a given test time. From the weight of the fuel fed $\left(\mathrm{w}_{\mathrm{f}}\right)$ and the weight of the char collected $\left(\mathrm{w}_{\mathrm{c}}\right)$, the percent weight loss $(\mathrm{V})$ was calculated by equation $4-1$ :

$$
V=\left[\frac{w_{f}-w_{c}}{w_{f}}\right] \times 100
$$

The reactivity $R$, at a given DTR temperature, was then calculated by equation 42 :

$$
R=\frac{\frac{V}{V_{\infty}}}{t_{r}}
$$

where $\mathrm{V}_{\infty}$ is the maximum percent weight loss that occurs at any DTR temperature, and $t_{r}$ is the residence time of the fuel particle in the DTR. The particle residence time was calculated by dividing the length (L) that the particle travels through the region of the 
DTR that is at the desired temperature, by the particle velocity. The particle velocity is the sum of two components: the gas stream velocity $\left(V_{g}\right)$ and the terminal velocity $\left(V_{t}\right)$.

$$
t_{r}=\frac{L}{V_{g}+V_{t}}
$$

The centerline gas velocity was approximated by doubling the bulk gas velocity. The bulk gas velocity is simply the volumetric gas flow rate divided by the cross sectional area of the tube inside the DTR. The terminal velocity was calculated by Stokes' law,

$$
V_{t}=\frac{g d_{p}^{2} \Delta \rho}{18 \mu}
$$

where $d_{p}$ is the average particle diameter, $\mu$ is the gas viscosity, $\Delta \rho$ is the density difference between the fuel particle and the carrier gas, and $\mathrm{g}$ is the gravitational constant. At a temperature of $1700{ }^{\circ} \mathrm{C}$, the calculated residence time for the coal particles was $186 \mathrm{~ms}$.

The kinetic calculations were performed to develop parameters for the Arrhenius equation, shown as 4-5.

$$
\mathrm{k}=\mathrm{A} \times \mathrm{e}^{-(\mathrm{E} / \mathrm{RT})}
$$

where $\mathrm{k}$ is the rate constant, $\mathrm{A}$ is the pre-exponential constant or frequency factor $(1 / \mathrm{sec})$, $\mathrm{E}$ is the activation energy ( $\mathrm{kcal} / \mathrm{mol}), \mathrm{R}$ is the ideal gas constant, and $\mathrm{T}$ is the temperature (Kelvin scale). The resulting kinetics calculations for the coals burned at Willow Island Generating Station and Albright Generating Station are summarized in Table 4-2.

Table 4-2. Kinetic Parameters for Coals Burned at Willow Island Generating Station and Albright Generating Station

\begin{tabular}{|l|c|c|}
\hline & \multicolumn{2}{|c|}{ Coal } \\
\hline & Willow Island & Albright \\
\hline Maximum Volatile Yield (\%) & 68.4 & 52.9 \\
Pre-exponential constant $(\mathrm{A} ; 1 / \mathrm{sec})$ & 89.5 & 10.7 \\
\hline Activation energy $(\mathrm{E} ; \mathrm{kcal} / \mathrm{mol})$ & 66.2 & 10.3 \\
\hline
\end{tabular}

The reactivities of these two coals are depicted in Figures 4-1 and 4-2.

PSU also determined char oxidation kinetics for the coals burned, using chars generated by devolatilization at $1700^{\circ} \mathrm{C}\left(3090^{\circ} \mathrm{F}\right)$ in order to determine the kinetics of chars generated under typical combustion temperatures. The technique used to determine char oxidation kinetics involved evaluating thermogravimetric analysis (TGA) data. The results are shown in Figures 4-3 and 4-4. 


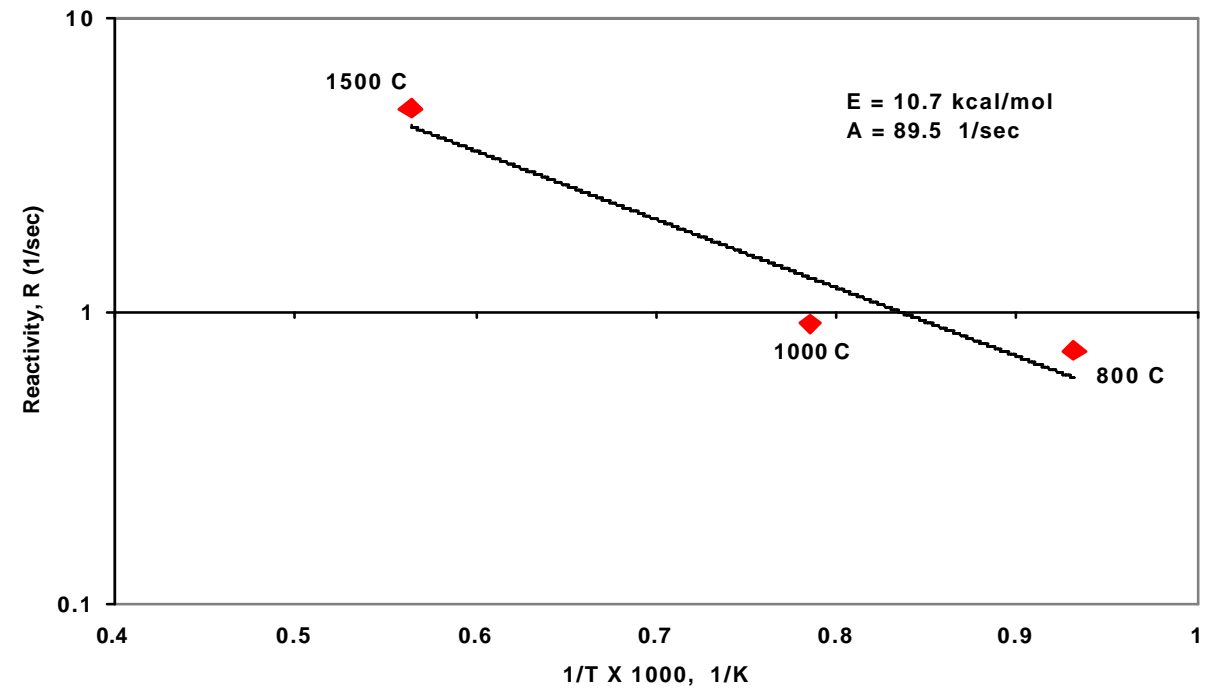

Figure 41. Devolatilization Reactivity of Coal Burned at Willow Island Generating Station

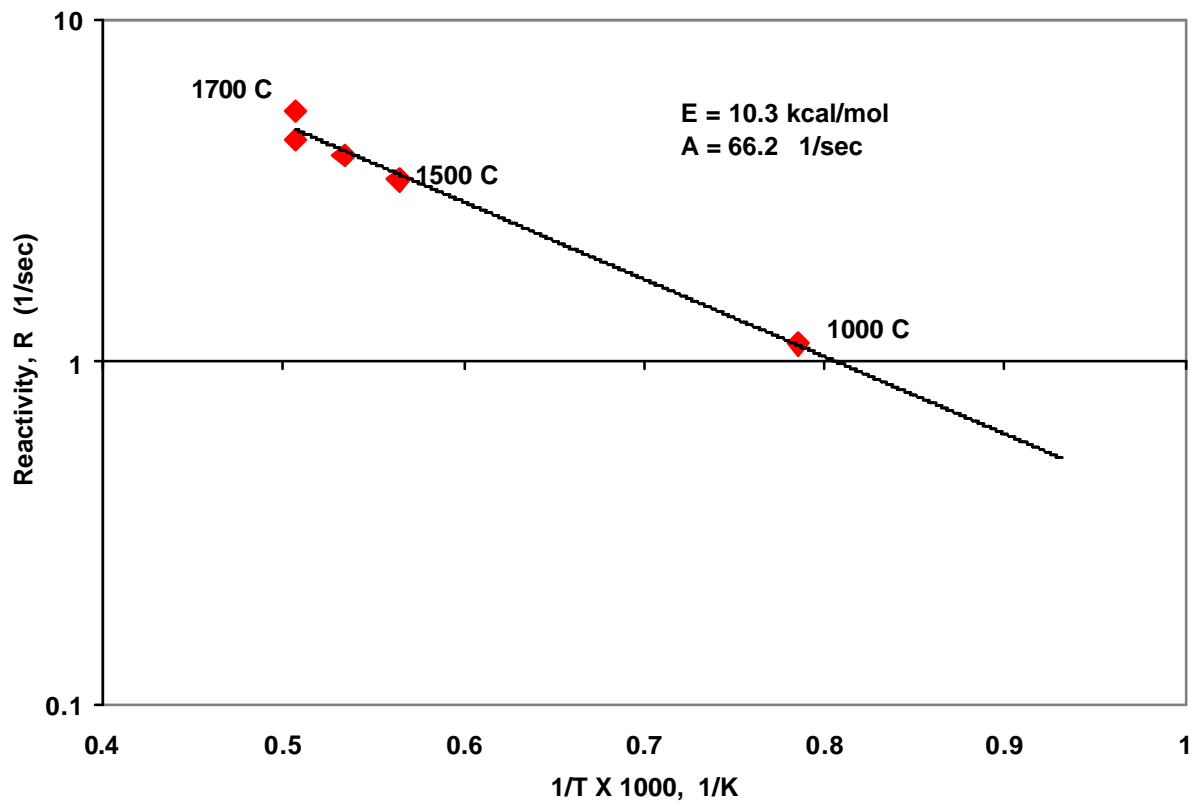

Figure 4-2. Devolatilization Reactivity of Coal Burned at Albright Generating Station. 


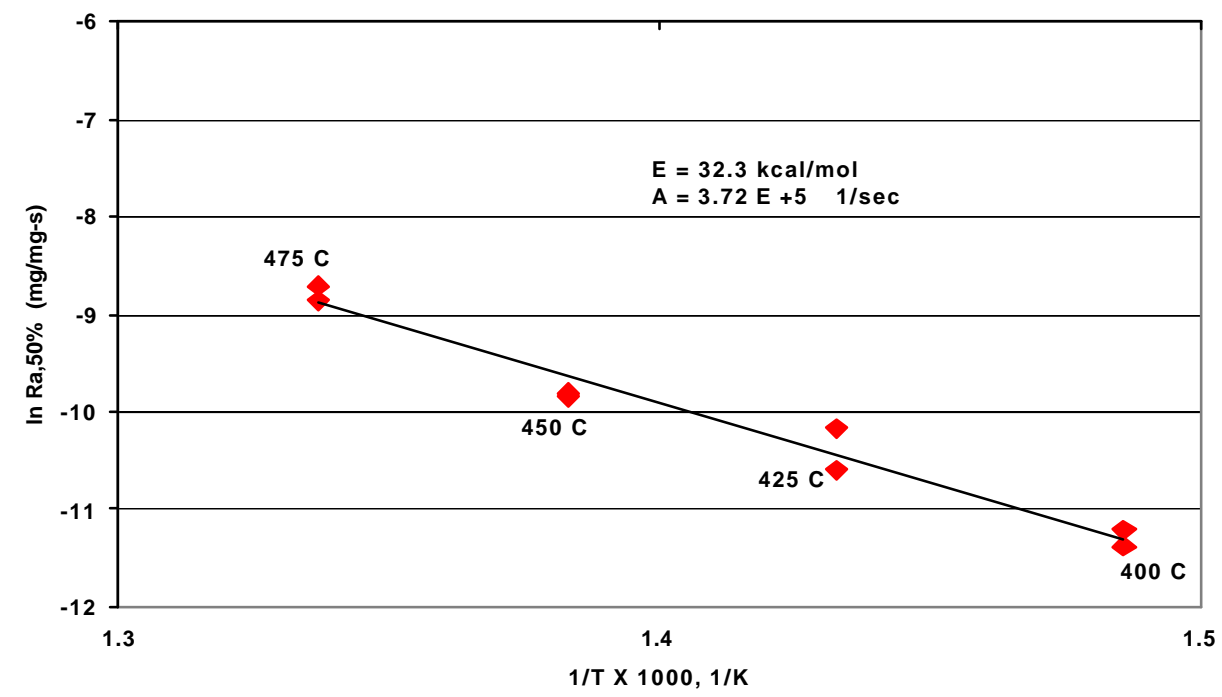

Figure 4-3. Char Oxidation Kinetics for Coal Burned at Willow Island Generating Station

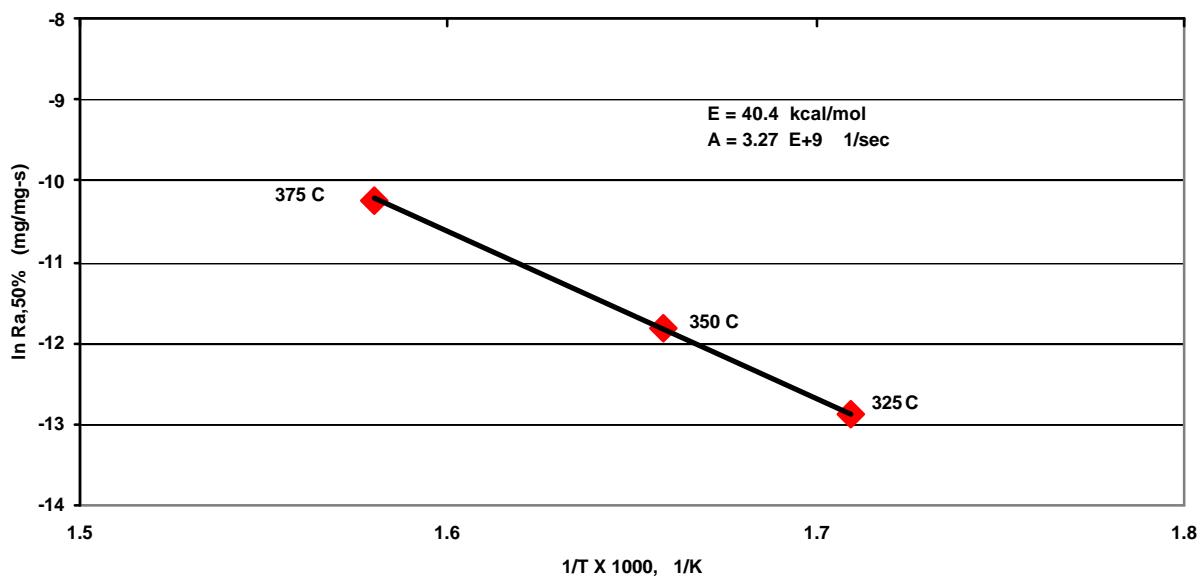

Figure 44. Char Oxidation Kinetics for Coal Burned at Albright Generating Station

Nitrogen evolution was the final issue addressed by the PSU coal characterizations. Baxter et. al. (1996) proposed a method for evaluating the potential of a fuel to create $\mathrm{NO}_{\mathrm{x}}$ emissions from conversion of fuel-bound nitrogen, evaluating the rate of volatile nitrogen evolution relative to total volatile evolution. Typically coals exhibit a lag between the rate of nitrogen evolution and the total rate of volatile evolution, implying that the nitrogen volatiles evolve more slowly than the total volatile mass. The fact that the nitrogen volatiles evolve more slowly carries the implication that these compounds 
are more likely to evolve in a fuel-lean environment, when $\mathrm{NO}_{\mathrm{x}}$ is more likely to be created.

The pattern of fuel nitrogen evolution for both Willow Island and Albright Generating Station coals is virtually identical. Figure 4-5 shows the relative rates of nitrogen and carbon evolution, along with the rate of total volatile evolution. Figure 4-5 shows the rate of volatile nitrogen evolution normalized against total volatile evolution, and compares these results to the rate of volatile carbon evolution normalized against total volatile evolution. Note the distinct lag in volatile nitrogen evolution at the inception of fuel particle devolatilization. Such a lag indicates significant potential for $\mathrm{NO}_{\mathrm{x}}$ formation from these fuels.

Given these data, the value of woody biomass cofiring can be evaluated from a fuels perspective. Note that it must be evaluated both for cyclone firing and for pulverized coal firing.

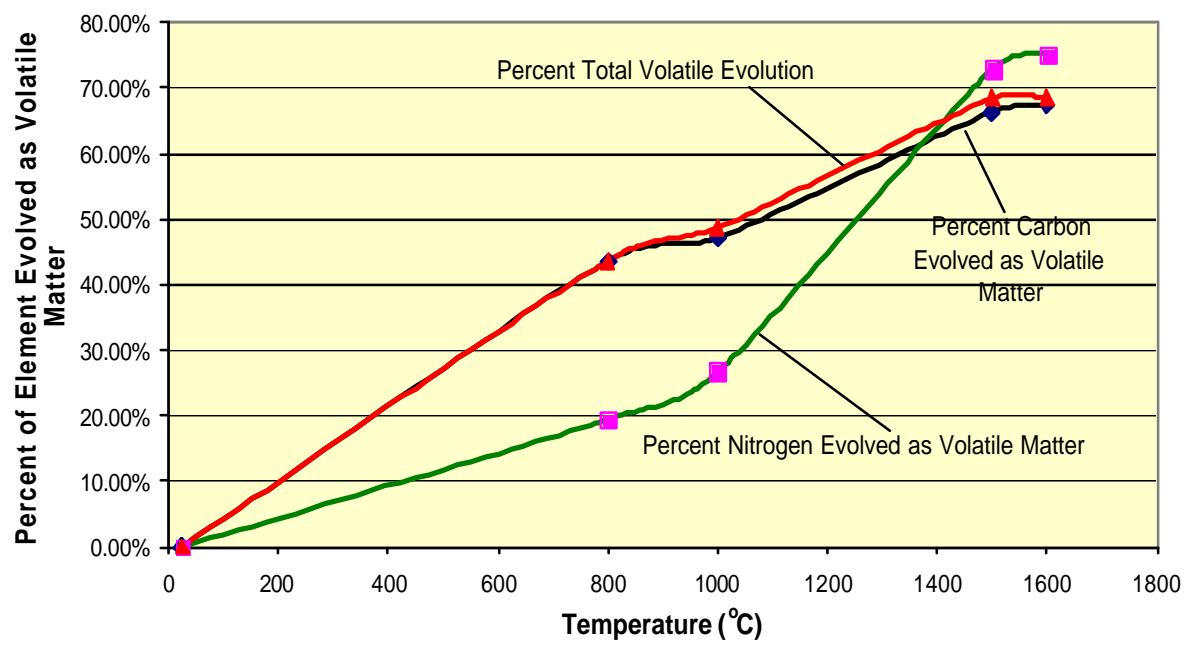

Figure 4-5. Nitrogen, Carbon, and Total Volatile Evolution as a Function of Temperature 


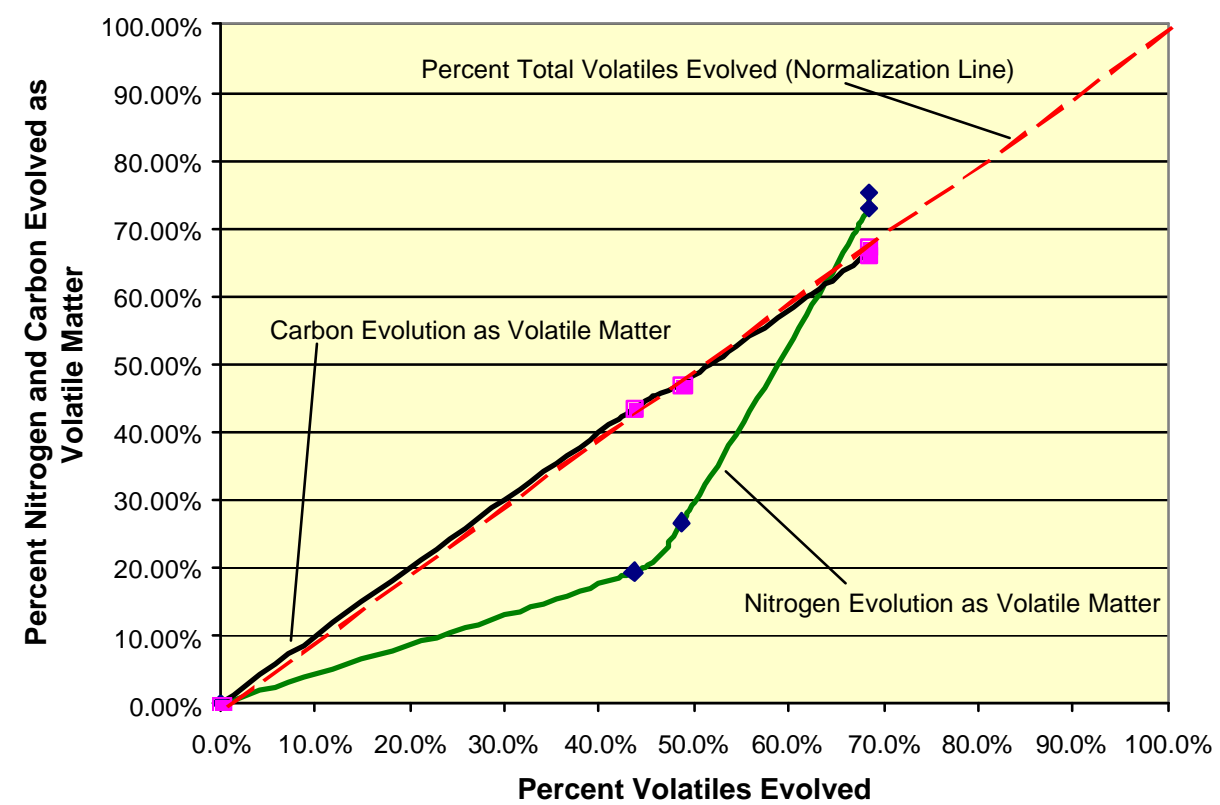

Figure 4-6. Volatile Nitrogen and Carbon Evolution Normalized to Total Volatile Evolution with Willow Island Coal.

The coals burned at Willow Island generally are generally medium slagging coals, with $\mathrm{T}_{250}$ temperatures in excess of $1,370^{\circ} \mathrm{C}\left(2,500^{\circ} \mathrm{F}\right)$. Some fluxing is practiced to reduce the $\mathrm{T}_{250}$ to lower temperatures. The mercury concentration in the coals burned at Willow Island is on the order of $0.18 \mathrm{mg} / \mathrm{kg}$ (Tillman, Payette, and Banfield, 2003).

\subsection{Characteristics of Sawdust Burned at Willow Island and Albright Generating Stations}

Allegheny Energy Supply Co., LLC. chose sawdust as its biomass fuel based upon a number of factors: 1) the plants chosen for the demonstration are located in areas with significant forest products activity, 2) agricultural materials such as switchgrass are not available and are inappropriate for cyclone firing, and 3) commercialization aspects of the demonstration favored using a biomass fuel where success parameters had been defined.

Extensive surveys of locally available sawdust were conducted for both generating stations. These surveys included interviews with local suppliers plus obtaining of samples for analysis. Because both demonstrations required a fuel particle nominally $6.35 \mathrm{~mm} \times 0 \mathrm{~mm}(1 / 4$ " $\times 0$ "), and because grinding of the entire fuel mass was not included in the demonstration concepts, fuel characterizations involved particle size as well as proximate and ultimate analysis, ash chemistry, and the advanced characterization as performed by PSU. 
Particle size distributions for the sawdust obtained from the Willow Island Generating Station survey are shown in Figures 4-7 and 4-8. Note that the sawdust sampled for Willow Island is virtually identical to that obtained for the Albright Generating Station with attention to particle size. Consequently it is used to represent both installations.

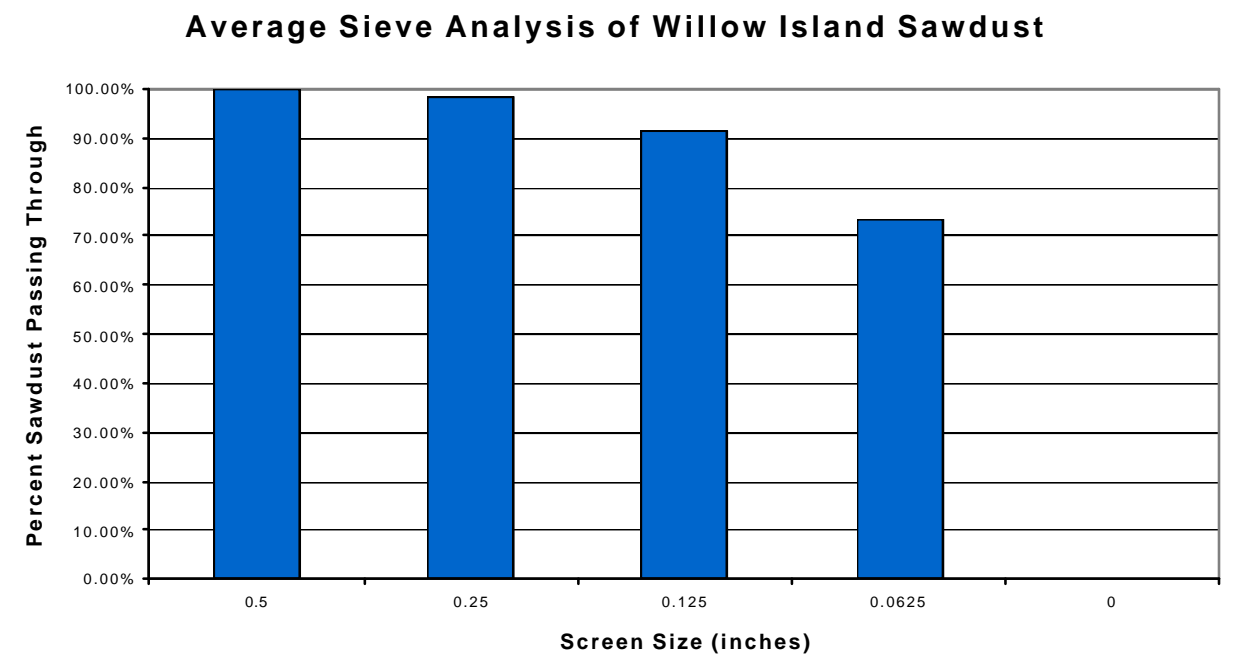

Figure 4-7. Sieve Analysis of Sawdust Obtained for the Willow Island Generating Station Demonstration.

(Source: Tillman, Payette, and Battista, 2000) 
Average Sieve Analysis of Willow Island Sawdust

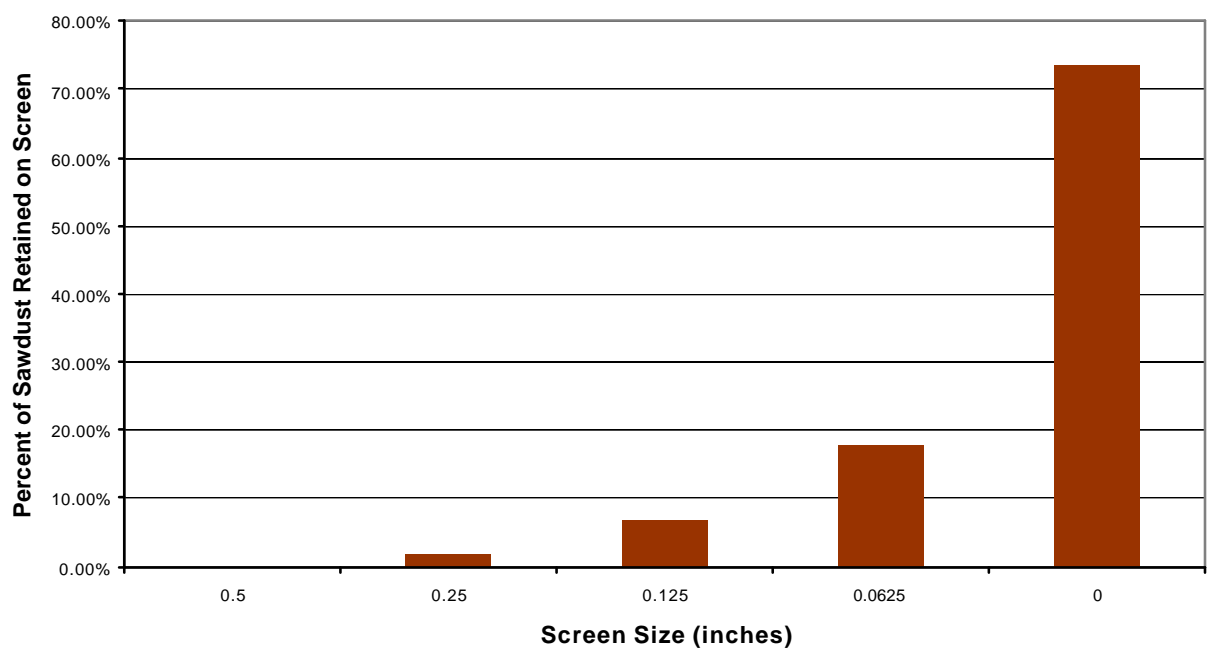

Figure 48. Sieve Analysis of the Sawdust Obtained for the Willow Island Generating Station Demonstration - 2

(Source: Tillman, Payette, and Battista, 2000)

The sawdust available, as measured by the samples, showed adequate particle size for the most part; with only $2-3$ percent exceeding the size requirement. However, 3 percent of $50-100$ tons/day still represents $1.5-3$ tons of reject material that must be accounted for in the design.

The proximate and ultimate analysis of the sawdust obtained for the Willow Island Generating Station can be found in Table 4-3. Note that this table highlights the consistency of this fuel. Consistency was an issue at the plants - and an issue readily resolved with the fuel characterizations.

The sawdust available to Albright Generating Station was quite similar to the sawdust available at Willow Island, as is shown in the comparison of ultimate analyses reported in Table 4-4. Note that the higher heating value of the sawdust available at Albright Generating Station was about 5 percent higher than that measured for the sawdust available at the Willow Island Generating Station. This distinction may be more apparent than real. 
Table 4-3. Fuel Characterization for Sawdust Available to Willow Island

\begin{tabular}{|c|c|c|c|c|c|}
\hline & Average & Standard & $95 \%$ & Minimum & Maximum \\
\hline & & Deviation & Conf. Int. & & \\
\hline \multicolumn{6}{|c|}{\begin{tabular}{|l|l} 
PROXIMATE ANALYSIS (wt $\%$ as received) & \\
\end{tabular}} \\
\hline Fixed Carbon & $9.29 \%$ & $1.28 \%$ & $0.72 \%$ & $6.43 \%$ & $11.17 \%$ \\
\hline Volatile Matter & $47.71 \%$ & $5.28 \%$ & $2.99 \%$ & $35.85 \%$ & $55.78 \%$ \\
\hline Ash & $0.90 \%$ & $0.72 \%$ & $0.41 \%$ & $0.13 \%$ & $2.47 \%$ \\
\hline Moisture & $42.10 \%$ & $5.82 \%$ & $3.30 \%$ & $32.53 \%$ & $55.25 \%$ \\
\hline \multicolumn{6}{|c|}{$\begin{array}{l}\text { ULTIMATE ANALYSIS (wt \% as received) } \\
\end{array}$} \\
\hline Carbon & $29.27 \%$ & $3.25 \%$ & $1.84 \%$ & $21.52 \%$ & $34.52 \%$ \\
\hline Hydrogen & $3.33 \%$ & $0.38 \%$ & $0.22 \%$ & $2.45 \%$ & $3.95 \%$ \\
\hline Oxygen & $24.30 \%$ & $2.69 \%$ & $1.53 \%$ & $18.26 \%$ & $28.38 \%$ \\
\hline Nitrogen & $0.08 \%$ & $0.02 \%$ & $0.01 \%$ & $0.05 \%$ & $0.10 \%$ \\
\hline Sulfur & $0.01 \%$ & $0.00 \%$ & $0.00 \%$ & $0.00 \%$ & $0.01 \%$ \\
\hline$\overline{\mathrm{Ash}}$ & $0.90 \%$ & $0.72 \%$ & $0.41 \%$ & $0.13 \%$ & $2.47 \%$ \\
\hline Moisture & $42.10 \%$ & $5.82 \%$ & $3.30 \%$ & $32.53 \%$ & $55.25 \%$ \\
\hline TOTAL & $100.00 \%$ & $0.00 \%$ & $0.00 \%$ & $100.00 \%$ & $100.00 \%$ \\
\hline \multicolumn{6}{|c|}{$\begin{array}{l}\text { HIGHER HEATING VALUE (MJ/kg) } \\
\end{array}$} \\
\hline As Received & 11.2 & 1.26 & 0.71 & 8.31 & 13.3 \\
\hline Dry & 19.3 & 0.36 & 0.20 & 18.6 & 19.8 \\
\hline \multicolumn{6}{|c|}{ HIGHER HEATING VALUE (Btu/lb) } \\
\hline As Received & 4828 & 543 & 307 & 3581 & 5758 \\
\hline Dry & 8330 & 155 & 88 & 8003 & 8534 \\
\hline Chlorides [ppmw, dry] & 522 & 374 & 212 & 124 & 1377 \\
\hline Chlorides [ppmw, as rec'd] & 307 & 225 & 127 & 55 & 842 \\
\hline
\end{tabular}

Source: Tillman, Payette, and Battista. 2000

Table 44. Comparison of Average Ultimate Analyses for the Sawdust Available at the Albright and Willow Island Generating Stations

\begin{tabular}{|c|c|c|c|}
\hline \multirow{2}{*}{ Parameter } & \multicolumn{2}{|c|}{ Generating Station } & \multirow{2}{*}{ Difference } \\
\hline & Albright & Willow Island & \\
\hline \multicolumn{4}{|c|}{ Ultimate Analysis (wt \% as received) } \\
\hline Carbon & 29.87 & 29.27 & +0.6 \\
\hline Hydrogen & 3.51 & 3.33 & +0.18 \\
\hline Oxygen & 26.66 & 24.30 & +2.36 \\
\hline Nitrogen & 0.12 & 0.08 & +0.04 \\
\hline Sulfur & 0.01 & 0.01 & --- \\
\hline Moisture & 39.53 & 42.10 & -2.57 \\
\hline Ash & 0.30 & 0.90 & -0.6 \\
\hline \multicolumn{4}{|l|}{ Higher Heating Value } \\
\hline $\mathrm{MJ} / \mathrm{kg}$ & 11.8 & 11.2 & +0.6 \\
\hline $\mathrm{Btu} / \mathrm{lb}$ & 5087 & 4828 & +259 \\
\hline
\end{tabular}


The two stations burned essentially the same fuel.

The ash characteristics for the Willow Island fuel are shown in Table 4-5. Note that the ash concentrations of the biomass fuels are sufficiently low that they are of little consequence in the combustion system. Note, also, that the sawdust contains a lignitic ash with significant concentrations of alkali metals and alkali earth elements.

Table 4-5. Ash Characterization of Sawdust Available to Willow Island

\begin{tabular}{l|l|l|l|l|l|}
\hline & Average & Standard & $95 \% \mathrm{CI}$ & Minimum & Maximum \\
\hline $\begin{array}{l}\text { ASH ELEMENTAL } \\
\text { ANALYSIS }\end{array}$ & & Deviation & & & \\
\hline $\mathrm{Compound}$ & & & & & \\
\hline $\mathrm{SiO}_{2}$ & $24.37 \%$ & $14.58 \%$ & $8.26 \%$ & $8.80 \%$ & $56.70 \%$ \\
\hline $\mathrm{Al}_{2} \mathrm{O}_{3}$ & $3.83 \%$ & $2.20 \%$ & $1.25 \%$ & $1.50 \%$ & $8.40 \%$ \\
\hline $\mathrm{TiO}_{2}$ & $0.17 \%$ & $0.15 \%$ & $0.08 \%$ & $0.00 \%$ & $0.50 \%$ \\
\hline $\mathrm{Fe}_{2} \mathrm{O}_{3}$ & $2.34 \%$ & $2.00 \%$ & $1.13 \%$ & $0.70 \%$ & $7.90 \%$ \\
\hline $\mathrm{MgO}$ & $33.51 \%$ & $8.63 \%$ & $4.89 \%$ & $18.20 \%$ & $47.10 \%$ \\
$\mathrm{NaO}_{2} \mathrm{O}$ & $2.56 \%$ & $1.57 \%$ & $0.89 \%$ & $0.90 \%$ & $5.20 \%$ \\
\hline $\mathrm{K}_{2} \mathrm{O}$ & $0.29 \%$ & $0.22 \%$ & $0.13 \%$ & $0.05 \%$ & $0.70 \%$ \\
\hline $\mathrm{SO}$ & $14.94 \%$ & $7.22 \%$ & $4.09 \%$ & $2.20 \%$ & $25.70 \%$ \\
$\mathrm{P}_{2} \mathrm{O}_{5}$ & $1.53 \%$ & $0.62 \%$ & $0.35 \%$ & $0.60 \%$ & $2.40 \%$ \\
\hline $\mathrm{Base/Acid} \mathrm{Ratio}$ & $1.54 \%$ & $0.89 \%$ & $0.50 \%$ & $0.30 \%$ & $3.00 \%$ \\
\hline & 2.62 & 1.58 & 0.89 & 0.50 & 5.62 \\
\hline $\mathrm{MERCURY} \mathrm{ANALYSIS}$ & & & & & \\
\hline mg/kg as received & 0.0013 & 0.0005 & 0.0003 & 0.0010 & 0.0020 \\
\hline mg/kg, dry wt basis & 0.0023 & 0.0007 & 0.0004 & 0.0020 & 0.0040 \\
\hline $\mathrm{SOu}$
\end{tabular}

Source: Tillman, Payette, and Battista. 2000.

Finally, note the very low concentrations of mercury. Mercury concentrations measured in the sawdust available at Albright Generating Station were $0.003-0.009 \mathrm{mg} / \mathrm{kg}$ asreceived. This was slightly higher than the mercury concentrations measured in the sawdust available to Willow Island Generating Station (see Table 4-5). The mercury concentrations in both sets of sawdust are substantially lower than the concentrations of mercury in the coals burned at Willow Island and Albright Generating Stations, even when compensating for the differences in heat content.

The measurements made by PSU concerning structure indicated aromaticity of only 8 percent. Literature concerning wood indicates that the aromatic structures would exist as single benzene rings rather than as fused aromatic structures of two or more rings.

The measurements made by PSU concerning devolatilization and char oxidation kinetics showed that devolatilization or pyrolysis of the sawdust available commenced at low temperatures, occurred in a 2-stage mechanism, and was virtually complete by the 
temperature of $1000^{\circ} \mathrm{C}\left(1830^{\circ} \mathrm{F}\right)$. As expected from the proximate and ultimate analyses, this is a highly reactive fuel. Table 4-6 summarizes the kinetic measurements. The figures 4-9 through 4-11 detail the kinetic measurements by PSU (Johnson et. al. 2003; Johnson et. al., 2001).

Table 4-6. Reactivity and Kinetic Characteristics of Sawdust Burned by Allegheny

\begin{tabular}{|r|c|}
\hline Parameter & Value \\
\hline Maximum volatile yield & 95 percent \\
\hline Low Temperature Devolatilization Kinetics & $400-600^{\circ} \mathrm{C}$ \\
\hline Pre -exponential constant A (1/sec) & 1.17 \\
Activation energy E $(\mathrm{kcal} / \mathrm{mol})$ & 0.681 \\
\hline High Temperature Devolatilization Kinetics & $600-1000^{\circ} \mathrm{C}$ \\
\hline Pre-exponential constant A (1/sec) & 5.74 \\
\hline Activation energy E (kcal/mol) & 3.42 \\
Char Oxidation Kinetics & $1.63 \mathrm{E}+5$ \\
\hline Pre-exponential constant A (1/sec) & 25.7 \\
\hline Activation energy E (kcal/mol) &
\end{tabular}

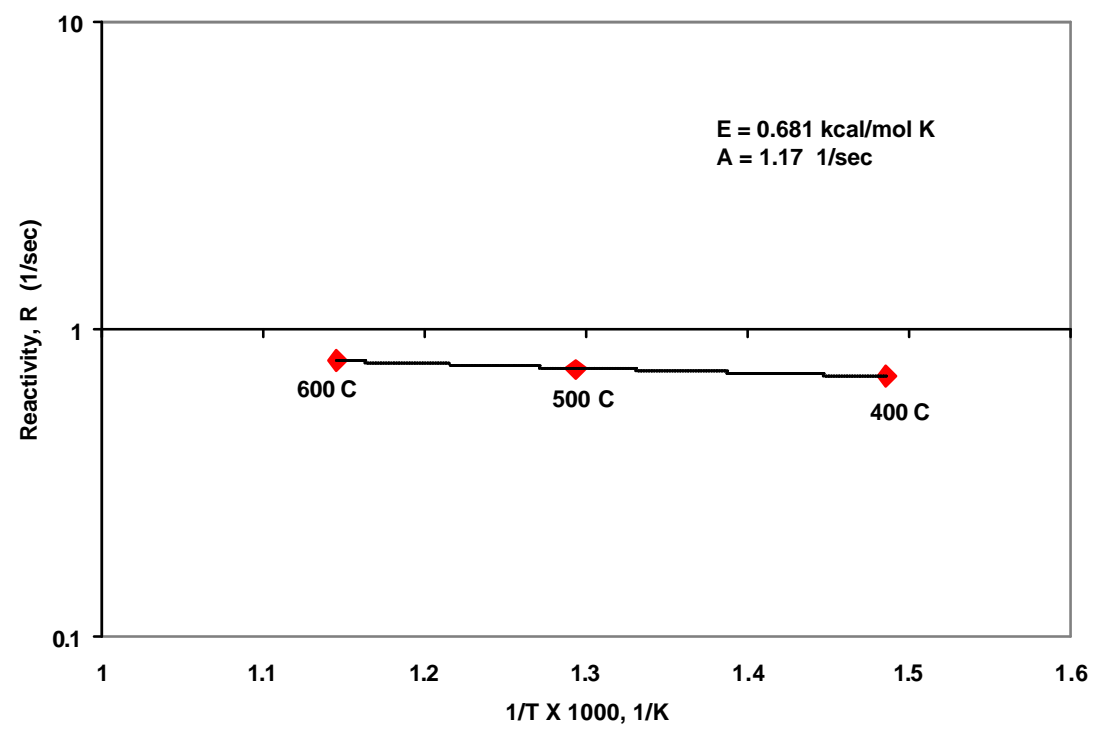

Figure 49. Low Temperature Devolatilization Kinetics for Sawdust used by Allegheny 


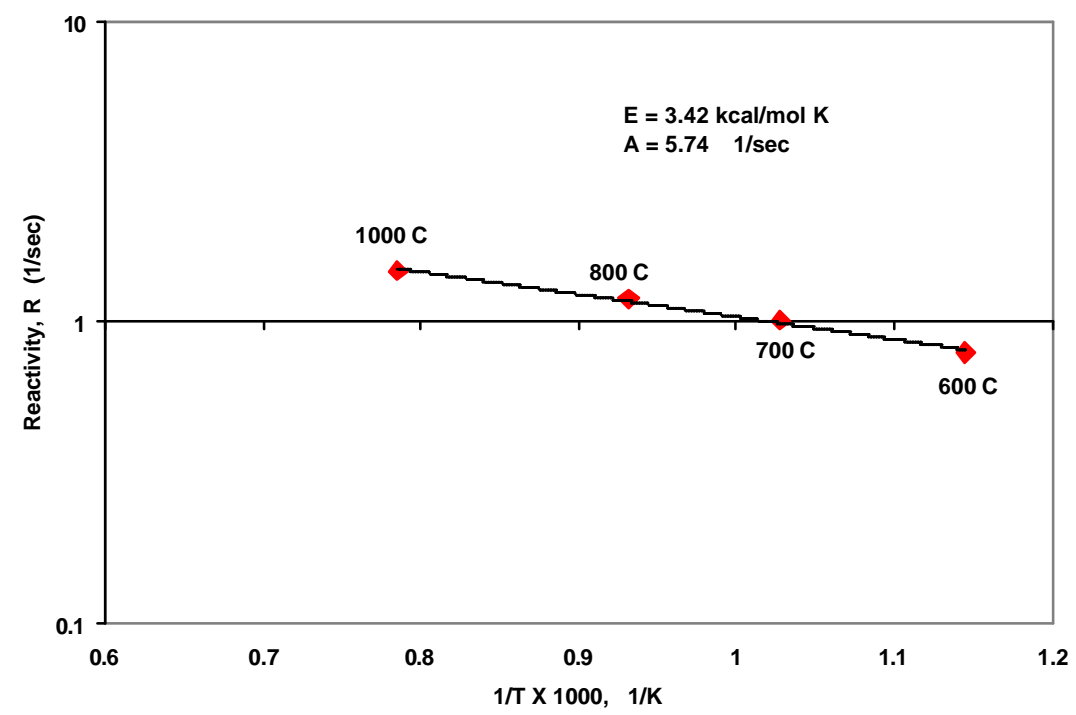

Figure 410. High Temperature Devolatilization Kinetics for Sawdust used by Allegheny

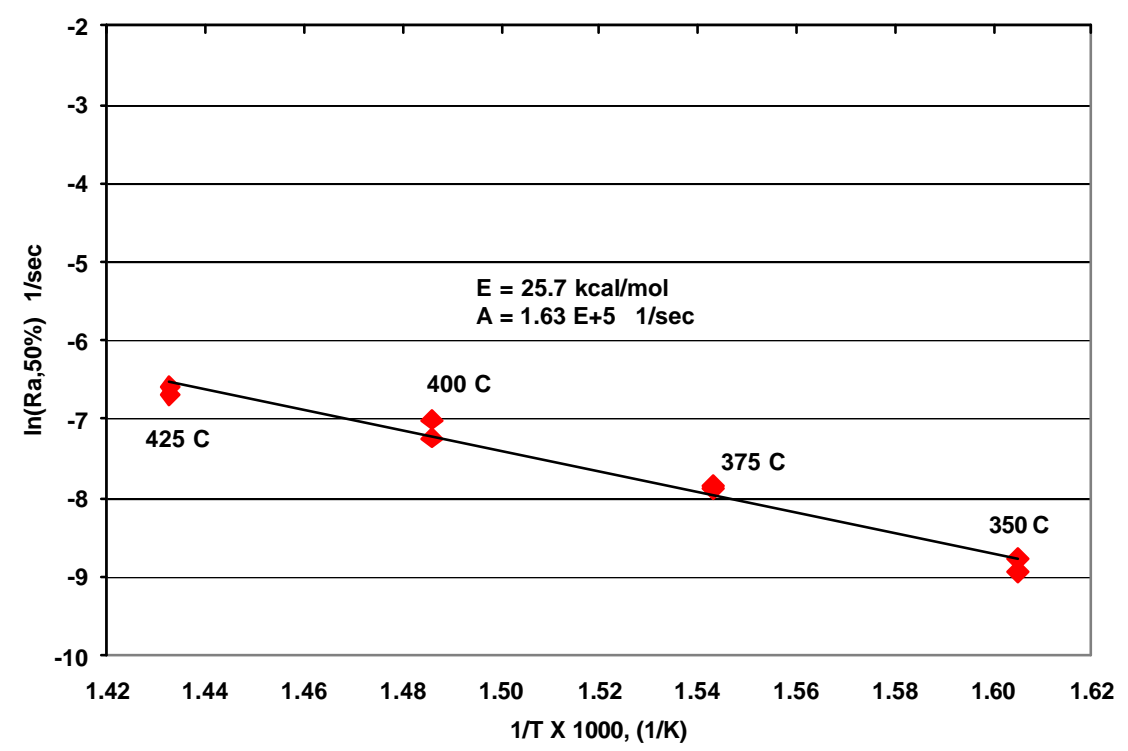

Figure 411. Char Oxidation Kinetics for Sawdust Available to Allegheny Generating Stations

The final consideration is fuel nitrogen evolution. Note that there is very little fuel nitrogen in the sawdust. What volatile nitrogen exists (and virtually all of the nitrogen is volatile nitrogen) evolves very rapidly_- well in advance of the volatile carbon or total 
volatile mass as is shown in Figures 4-12 and 4-13 (see Johnson et. al., 2003; Tillman et. al., 2003).

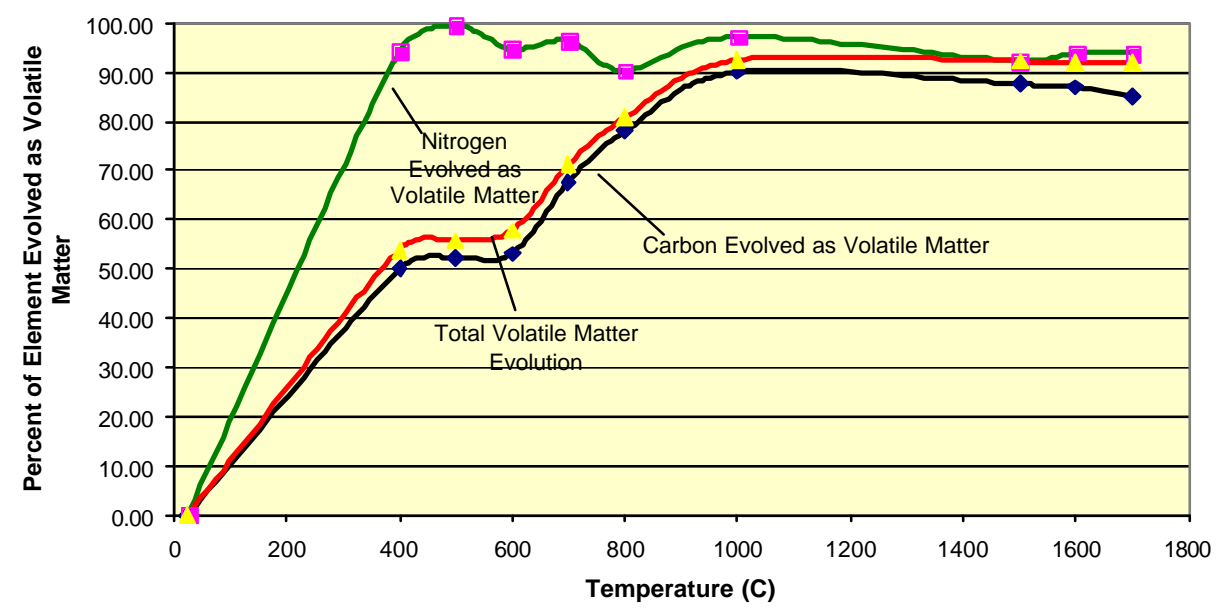

Figure 4-12. Carbon, Nitrogen, and Total Volatile Evolution from Sawdust

Normalized Nitrogen and Carbon Volatile Evolution for Sawdust

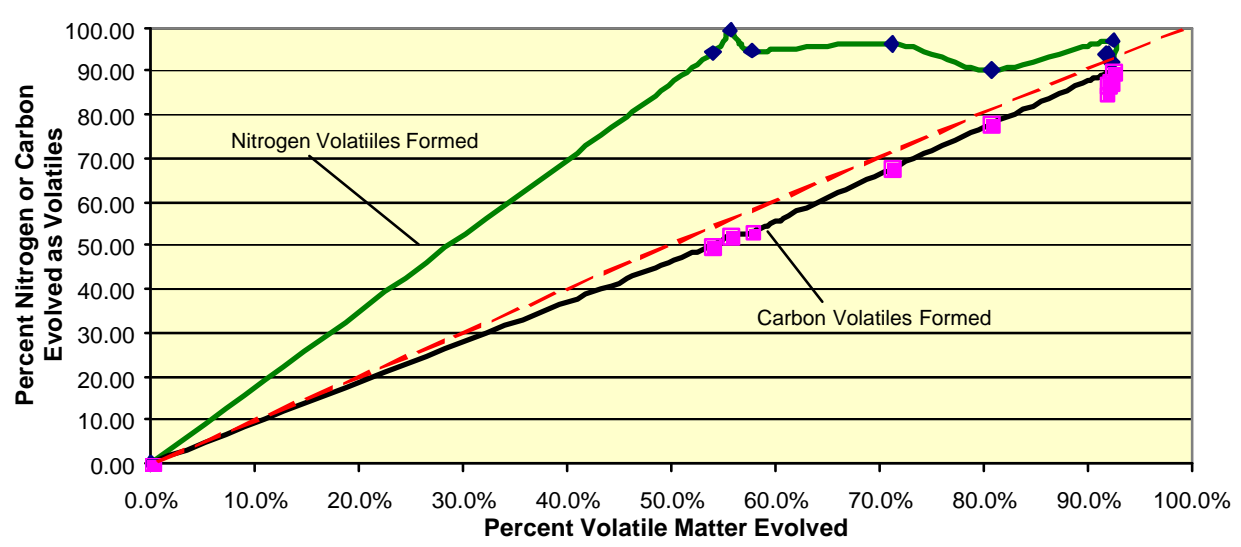

Figure 4-13. Normalized Volatile Nitrogen and Carbon Evolution from Sawdust

The conclusion that can be drawn form this extensive analysis is the sawdust is an excellent complement to the coals being burned at Willow Island and Albright Generating Stations. As such, the combination holds significant promise for the project. 


\subsection{Tire -derived Fuel}

Tire-derived fuel was the final component of the test program at Willow Island Generating Station. The TDF supplied to the plant was in the form of $2.5 \mathrm{~cm}$ (1 in) -3.8 $\mathrm{cm}$ (1.5 in) nominal chips. These conformed generally to the values shown in Table 4-7. The TDF provides the opportunity to enhance the calorific value of the feed to the cyclone boilers with the opportunity fuel, overcoming the modest calorific value of the sawdust. At the same time it is inherently low in fuel nitrogen and ash, particularly when presented on a $\mathrm{kg} / \mathrm{MJ}\left(\mathrm{lb} / 10^{6} \mathrm{Btu}\right)$ basis. 
Table 4-7. Characterization of Tire-Derived Fuel Available at Willow Island

\begin{tabular}{|c|c|c|}
\hline $\begin{array}{c}\text { PARAMETER } \\
\text { PROXIMATE ANALYSIS (Wt \%) }\end{array}$ & $\begin{array}{c}\text { As Received } \\
\text { Basis }\end{array}$ & Dry Basis \\
\hline Moisture & 0.62 & $-0-$ \\
\hline Ash & 4.78 & 4.81 \\
\hline Volatile Matter & 55.64 & 67.06 \\
\hline Fixed Carbon & 27.96 & 28.13 \\
\hline \multicolumn{3}{|l|}{ ULTIMATE ANALYSIS (Wt \%) } \\
\hline Carbon & 83.87 & 84.39 \\
\hline Hydrogen & 7.09 & 7.13 \\
\hline Oxygen & 2.17 & 2.19 \\
\hline Nitrogen & 0.24 & 0.24 \\
\hline Sulfur & 1.23 & 1.24 \\
\hline Moisture & 0.62 & $-0-$ \\
\hline Ash & 4.78 & 4.81 \\
\hline HIGHER HEATING VALUE (MJ/kg) & 37.7 & 37.8 \\
\hline HIGHER HEATING VALUE (Btu/lb) & 16250 & 16300 \\
\hline
\end{tabular}




\subsection{The Willow Island Demonstration: Design and Construction}

Willow Island Generating Station houses two boilers: a 55 MWe down-fired pulverized coal boiler and a $188 \mathrm{MWe}$ (net) cyclone boiler. The cyclone boiler was the site of this demonstration.

\subsection{Project Overview}

Cofiring of wood wastes with coal has been demonstrated as an effective means for using biomass in cyclone boilers; demonstrations have occurred at the Allen Fossil Plant of TVA, the Michigan City Generating Station of NIPSCO, and the Bailly Generating Station (BGS) of NIPSCO. In these demonstrations, $\mathrm{NO}_{\mathrm{x}}, \mathrm{SO}_{2}$, and fossil-based $\mathrm{CO}_{2}$ emissions reductions occurred. In each case, the volatility of the wood waste created the mechanism for $\mathrm{NO}_{\mathrm{x}}$ reduction; the use of a sulfur-free fuel reduced $\mathrm{SO}_{2}$ emissions. Testing at BGS opened investigation into designing blends of opportunity fuels to optimize cofiring. At BGS, urban wood waste is mixed with petroleum coke at a specified blend to optimize $\mathrm{NO}_{\mathrm{x}}$ emissions management while accomplishing the goals of fossil $\mathrm{CO}_{2}$ emissions reductions. The $\mathrm{NO}_{\mathrm{x}}$ emissions reductions at BGS are $\sim 30$ percent when firing the designed opportunity fuel blend (see Tillman, 2001; Tillman, 1999).

The Willow Island demonstration blended sawdust with TDF to create a new opportunity fuel for cofiring in a cyclone boiler equipped with a separated overfire air system. This demonstration created a second opportunity fuel blend that was intended to offer the potential for reducing $\mathrm{NO}_{\mathrm{x}}$ emissions generated by the combustion process. At the same time the demonstration addres sed the potential for reducing $\mathrm{SO}_{2}$ emissions along with fossil $\mathrm{CO}_{2}$ emissions and heavy metal emissions. The initial concept also included the potential for using biomass cofiring to enhance the performance of the electrostatic precipitator (ESP). The Willow Island plant "hot-side" ESP requires the use of a sodium additive to enhance the resistivity of the flyash particles. This demonstration examined the potential of biofuel cofiring to obviate the need for such additives in the control of particulates and opacity_capitalizing upon the potassium and sodium content of the biomass ash. This potential, however, did not materialize.

\subsection{System Design}

The design basis included a process concept to deliver, to the boiler, an opportunity fuel comprised of both sawdust and tire-derived fuel. This concept was based upon the recognition that blending two fuels together does not produce an average of those fuels; rather it produces a third-unique-energy source. Consequently the effort was made to create a designer opportunity fuel. 


\subsubsection{Combustion Modeling}

The designer opportunity fuel program relied significantly upon computational fluid dynamics (CFD) modeling as performed by Reaction Engineering International in association with N.S. Harding and Associates. The CFD modeling was used to predict the potential outcomes associated with using this blend of fuels.

Working with these data, plus information on the TDF, Reaction Engineering Internationa and N.S. Harding and Associates modeled the Willow Island cyclone barre ls and total furnace. This modeling, using computational fluid dynamics (CFD) techniques, predicted cyclone barrel temperature profiles, combustion completeness, and $\mathrm{NO}_{\mathrm{x}}$ emissions. Table 5-1 shows the particle burnout results modeled for the cyclone barrel including a baseline case, a case with 85 percent coal/10 percent sawdust $/ 5$ percent TDF, and a case with 90 percent coal/10 percent sawdust. All percentages are on a mass basis.

Table 5-1. Modeling Results at Willow Island

\begin{tabular}{|c|c|}
\hline Case & Particle Burnout (\%) \\
\hline Baseline (100\% coal) & 94.2 \\
\hline $85 \%$ coal/10\% sawdust $/ 5 \% \mathrm{TDF}$ & 96.5 \\
$90 \%$ coal/10\% sawdust & 96.2 \\
\hline
\end{tabular}

The CFD modeling also showed that the $85 \%$ coal $/ 10 \%$ sawdust $/ 5 \%$ TDF case increased the cyclone exit temperature by $\sim 130^{\circ} \mathrm{F}$ while the $90 \%$ coal $/ 10 \%$ sawdust case decreased the cyclone exit temperature by only $\sim 23^{\circ} \mathrm{F}$. The cofiring practice does not influence the cyclone temperatures appreciably_except to increase these temperatures modestly when TDF is introduced. However the modeling clearly indicates increased particle burnout and a $\sim 10$ percent decrease in $\mathrm{NO}_{\mathrm{x}}$ emissions when cofiring or trifiring. Figures 5-1 through 5-3 show these temperature profiles. 


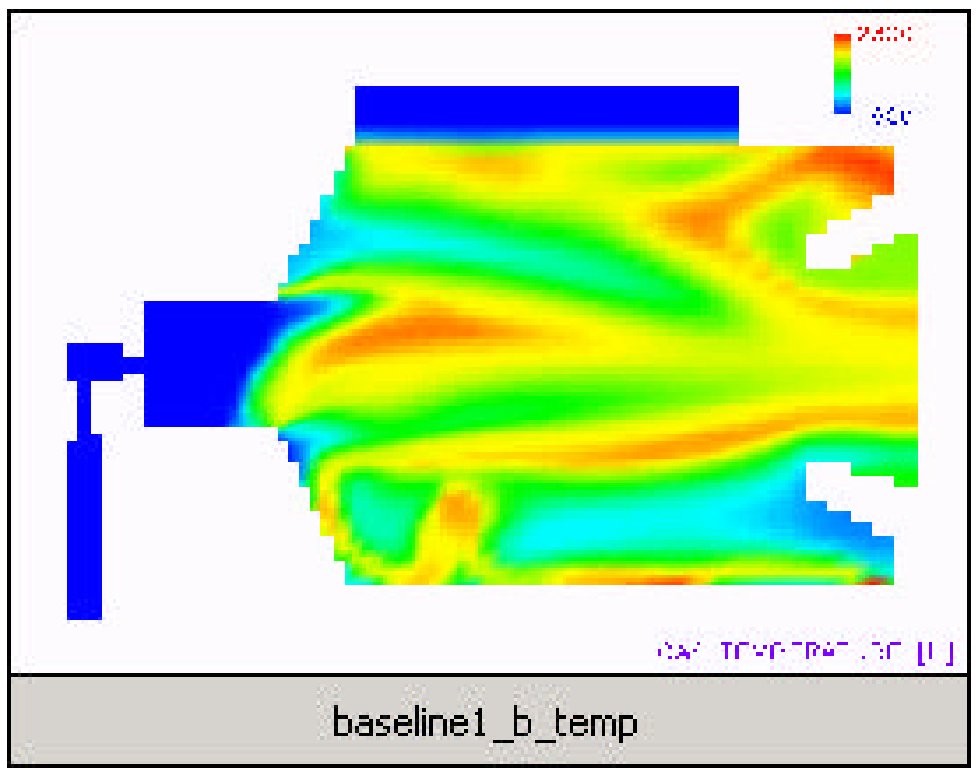

Figure 5-1. Temperature Profile of a Willow Island Cyclone Barrel Firing 100\% Coal

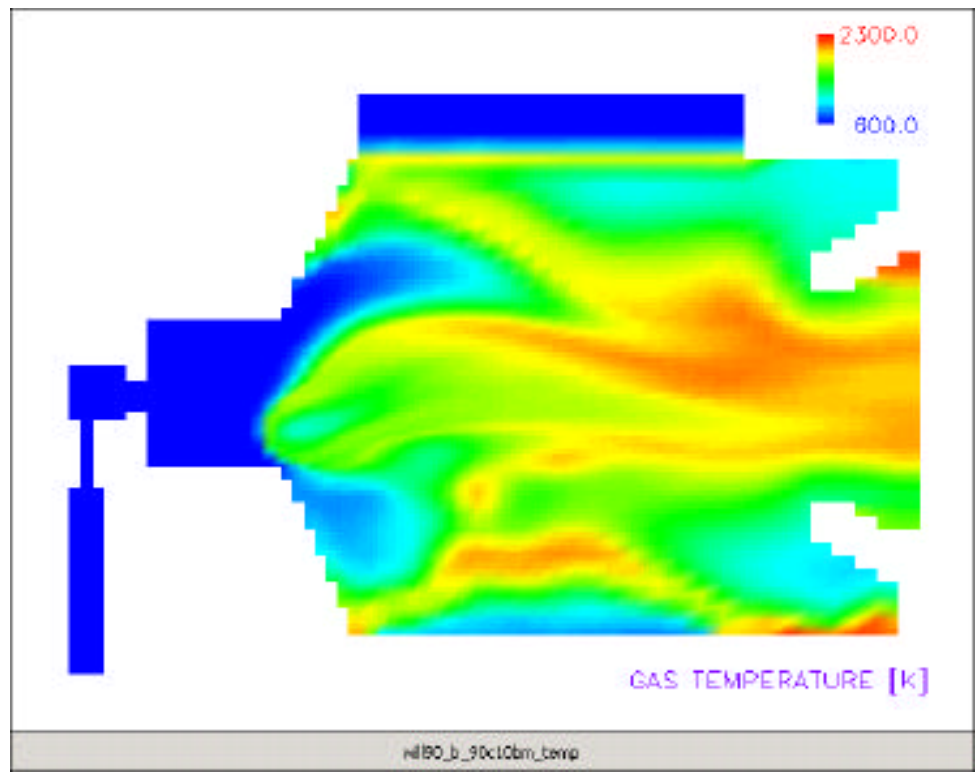

Figure 5-2. Temperature Profile of a Willow Island cyclone barrel cofiring coal, and sawdust 


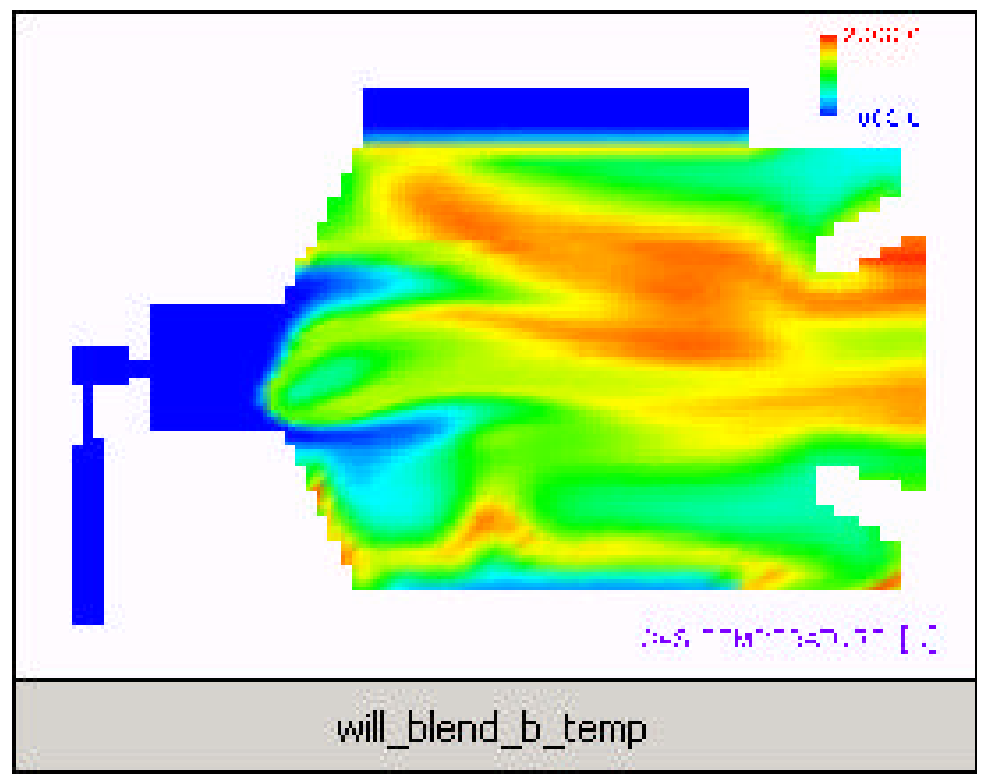

Figure 5-3. Temperature Profile of a Willow Island cyclone barrel trifiring coal, sawdust, and TDF

The modeling by Reaction Engineering clearly showed that there would be minimal impact of cofiring on cyclone combustion temperatures, however there would be an increase in combustion completeness within the cyclone barrel. Carbon conversion (to $\mathrm{CO}_{2}$ ) would reach and exceed 96.5 percent, compared to less than 94.2 percent when firing only coal. The modeling indicated no appreciable change in furnace exit gas temperature (FEGT). The furnace temperature profile when firing a blend of 85 percent coal/10 percent sawdust/5 percent TDF is shown in Figure 5-4. 


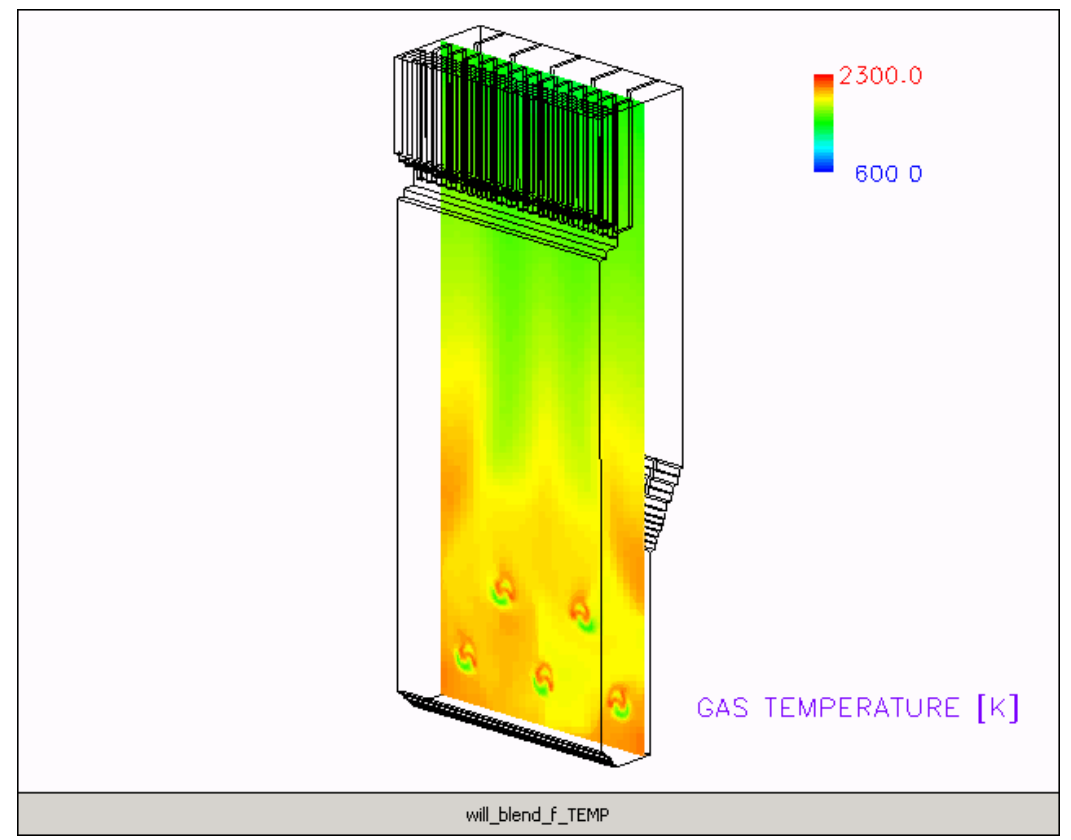

Figure 5-4. Temperature modeling of the furnace firing a blend of 85 percent coal/10 percent sawdust/5 percent TDF.

The modeling showed no decrease in $\mathrm{NO}_{\mathrm{x}}$ when cofiring biomass in an unstaged mode, and a $10+$ percent decrease in $\mathrm{NO}_{\mathrm{x}}$ emissions when cofiring the designer opportunity fuel in a staged mode. The modeling by Reaction Engineering International showed that the mechanism for NOx reduction with biomass cofiring involves enhancing staged combustion. This modeling provided a basis for continuing to pursue the demonstration.

\subsubsection{Process and Mechanical Engineering of the Willow Island Project}

The process concept for the Willow Island project was based upon the fact that Allegheny had already installed a system for blending TDF with coal. Consequently a system was designed to blend sawdust with the coal, and achieve independent control of the sawdust and TDF. This permitted a variety of opportunity fuel blends to be fired in the cyclone boiler. Further, it was based upon supplying $6.35 \mathrm{~mm}$ x $0 \mathrm{~mm}(1 / 4$ " x 0 ") sawdust to the boiler to maximize rapid burnout and $\mathrm{NO}_{\mathrm{x}}$ reduction potential. This system has been described previously by Tillman, Payette, Banfield, and Holt (2002) and by Tillman and Payette (2001).

Given the TDF system, the battery limits were established for the sawdust system. The sawdust system was to receive biomass fuels from outside storage. Its limit was the chute feeding the biomass onto the main coal belt. The process design was based upon blending the sawdust with the coal on the main coal belt, upstream of the automatic sampling system. Equipment was then selected based upon plant preferences and plant standards. This included the fact that all fuel handling was to be accomplished with 
mechanical systems, and without employing pneumatic systems. This single factor led to the selection of a live bottom bin for sawdust storage, rather than a silo, in order to keep the lifting of the sawdust to a reasonable height.

The equipment selected has been discussed by Tillman, Payette, and Banfield (2003). The initial approach involved receiving sawdust in walking floor vans. The initial fuel survey indicated that sufficient walking floor van capacity existed; however it would increase the cost of bringing sawdust to the plant by a modest amount. By using walking floor vans, the project saved significant capital expenditures traditionally associated with trailer dump systems. The screen selected was a disc screen. Trommel screens, deck screens, and other screening systems were evaluated. Disc screens, commonly used in the forest products industry, provided the best trade-off between a quality biomass product and dust generation.

A small grinding system for handling oversized particles was installed. The economics of grinding oversized particles, as opposed to landfilling such material, favored the increased capital cost of the grinder. A mechanical conveyor was used to bring product from the processing facility to the storage bin. A live-bottom bin was chosen over a silo due to plant preferences for mechanical handling, and for ease of maintenance on specific equipment items. The live bottom bin fed a twin counter-rotating auger system that metered the flow of sawdust to a weigh-belt conveyor. The weigh-belt conveyor then discharged the sawdust into a chute that discharged directly onto the main coal belt.

System capacities were as follows:

- Sawdust receiving - $50 \mathrm{ton} / \mathrm{hr}(2.5$ trucks $/ \mathrm{hr})$

- Disc screen - 50 ton $/ \mathrm{hr}$

- Sawdust storage - 400 tons (nominal; 300 tons, actual)

- Outfeed twin auger conveyor - $75 \mathrm{ton} / \mathrm{hr}$

- Weigh-belt feeder $-75 \mathrm{ton} / \mathrm{hr}$

The capacities were determined based upon the potential to fire up to 15 percent sawdust on a mass basis, and were based upon the current feed rate of coal to the bunkers. The design was such that the entire mass of sawdust, coal, and TDF could be loaded into the fuel bunkers within a 2-hour window.

The project also included installing a Diamond Power GasTemp ${ }^{\mathrm{TM}}$ probe at the nose of the Willow Island \#2 boiler in order to measure the furnace exit gas temperature (FEGT) associated with cofiring sawdust, and the designer opportunity fuel.

Figures 5-5 and 5-6 depict the design of the Willow Island system. Note the elevation, and the fact that the total height of the system was kept below $45 \mathrm{ft}$, including the foundations and walking floor bin. 


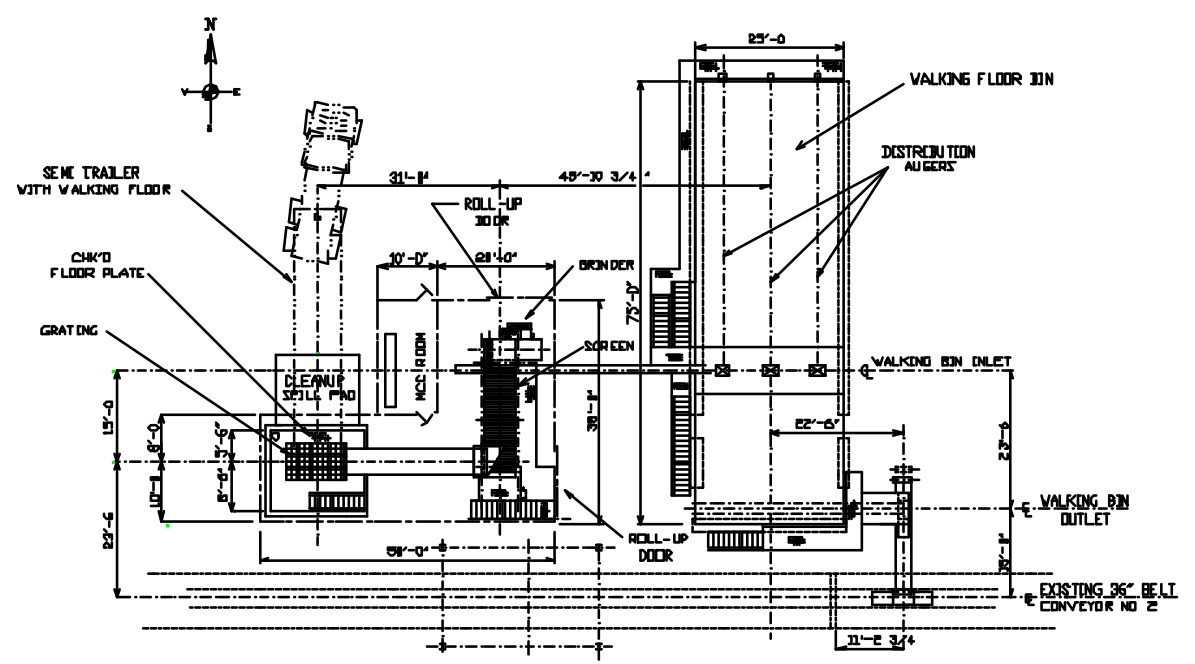

Figure 5-5. Plan View of the Willow Island Designer Fuel Cofiring System

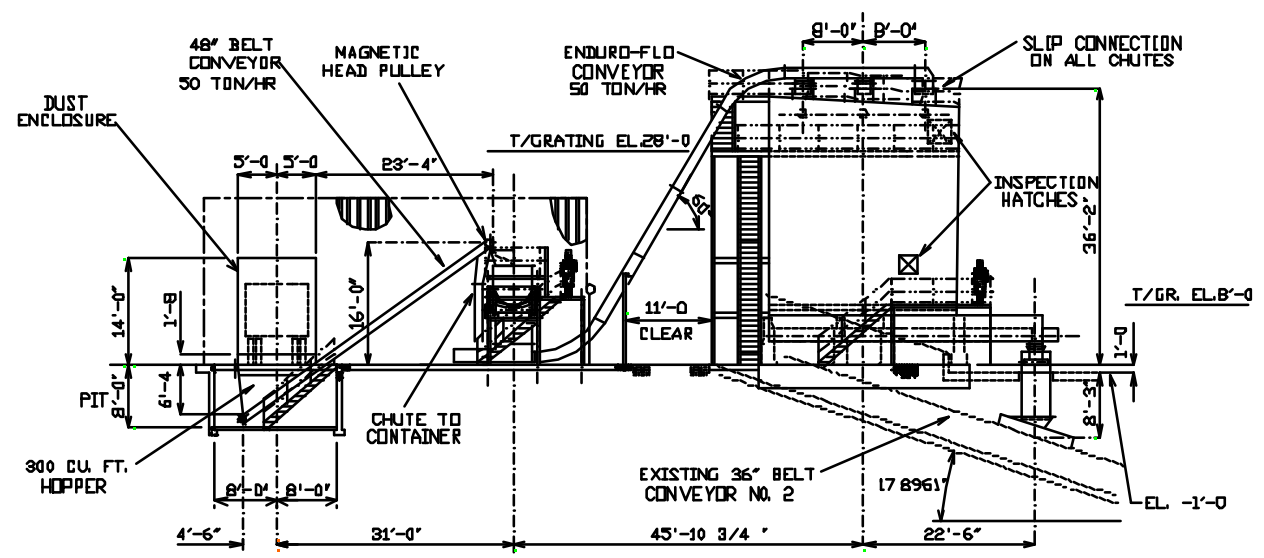

Figure 5-6. Elevation View of the Willow Island Cofiring Demonstration

\subsubsection{Civil, Structural, and Electrical Engineering}

Given the process and mechanical engineering, structural considerations emerged as a significant engineering issue. Soils tests conducted upon receipt of the award (see Figure 5-7) indicated poor quality soils and the need for significant installation of concrete piles in order to support the system. Auger cast piles were designed to support both the sawdust storage bin and the receiving and processing structure. 


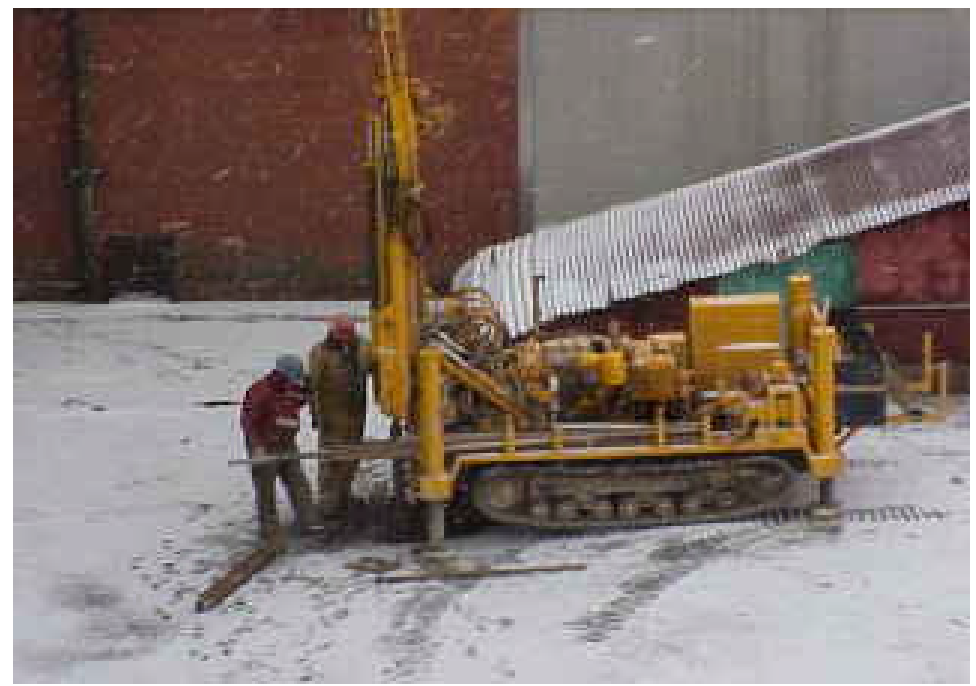

Figure 5-7. Geotechnical Soils Investigations Conducted at Willow Island in Dec. 2000

Electrical engineering was based upon the plant standard of using explosion-proof wiring to ensure safety during operations-including housekeeping washdowns. Electrical engineering also involved a significant commitment to motor control centers (MCC's) and related equipment.

\subsection{Construction of the Willow Island Cofiring Facility}

Demolition of two small structures located on the site of the cofiring facility occurred in December, 2000; this initiated construction of the facility (see Figure 58). This yielded a clean site for project construction as is shown in Figure 5-9.

Engineering of the Willow Island demonstration facility was essentially complete in April, 2001, and system installation commenced thereafter. Installation began with exploration for underground utilities and interferences. It then proceeded through excavation, sinking of auger cast piles, construction of foundations, and construction of facilities.

\subsubsection{Construction Photographs}

The process of constructing the project is best depicted through a selection of photographs from those taken throughout the project. 


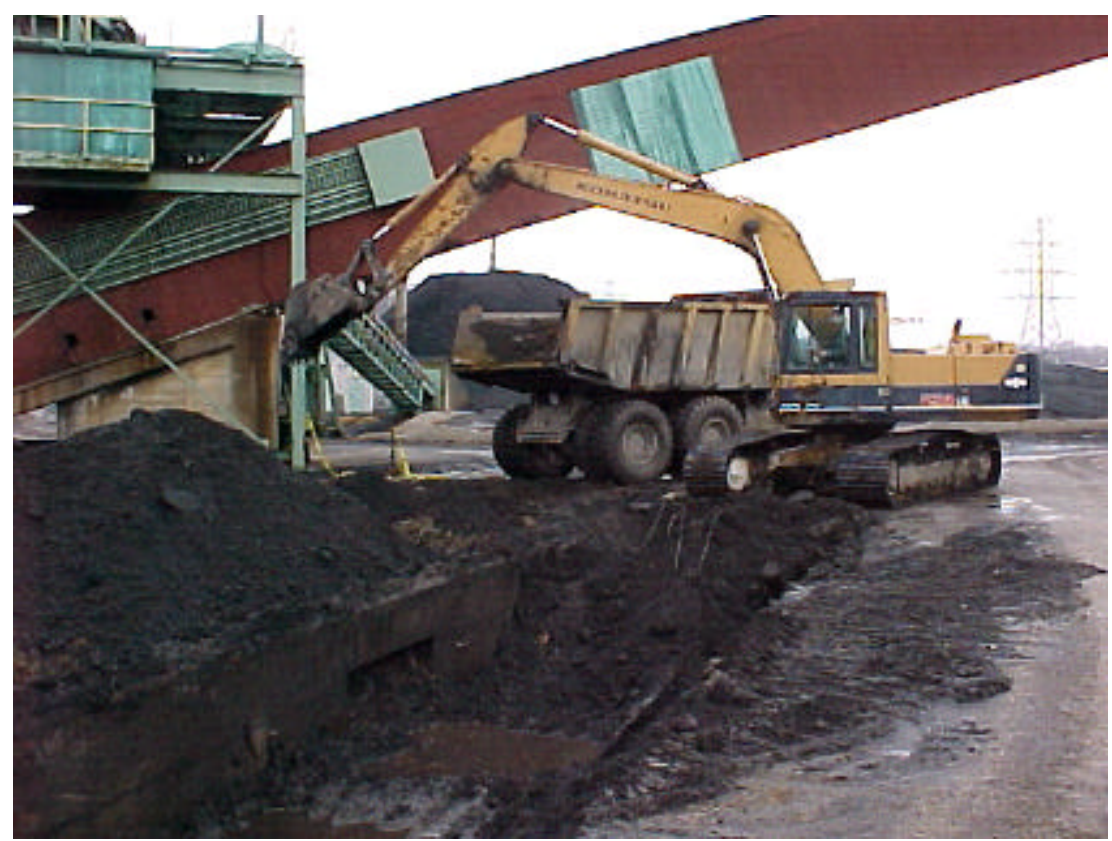

Figure 5-8. Demolition of small structures at Willow Island, initiating construction of the cofiring facility

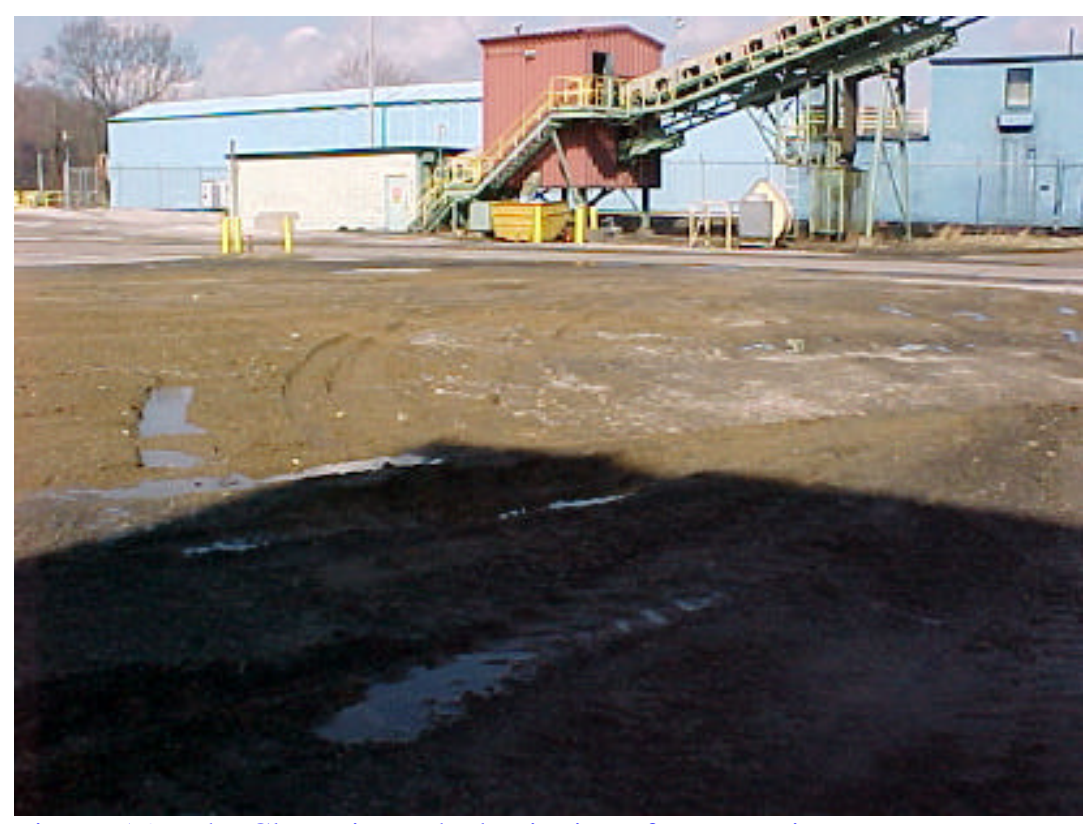

Figure 5-9. The Clean site at the beginning of construction 


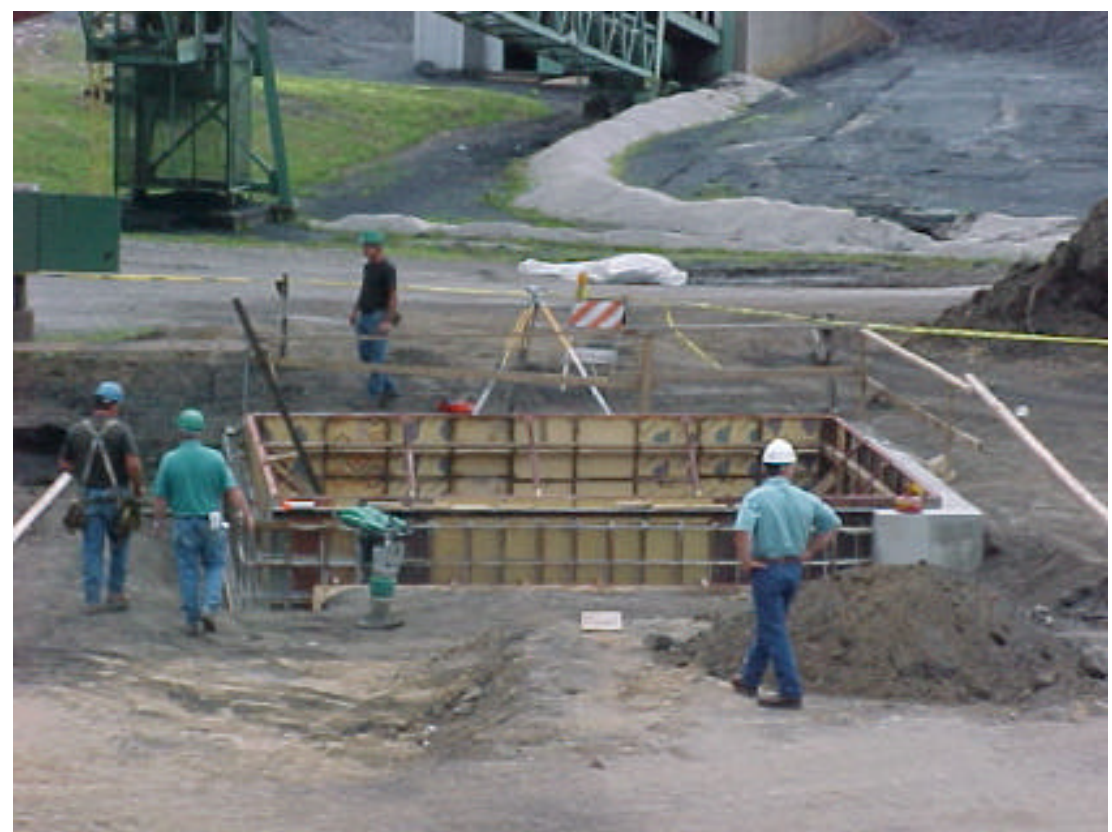

Figure 5-10. Construction of the fuel receiving pit

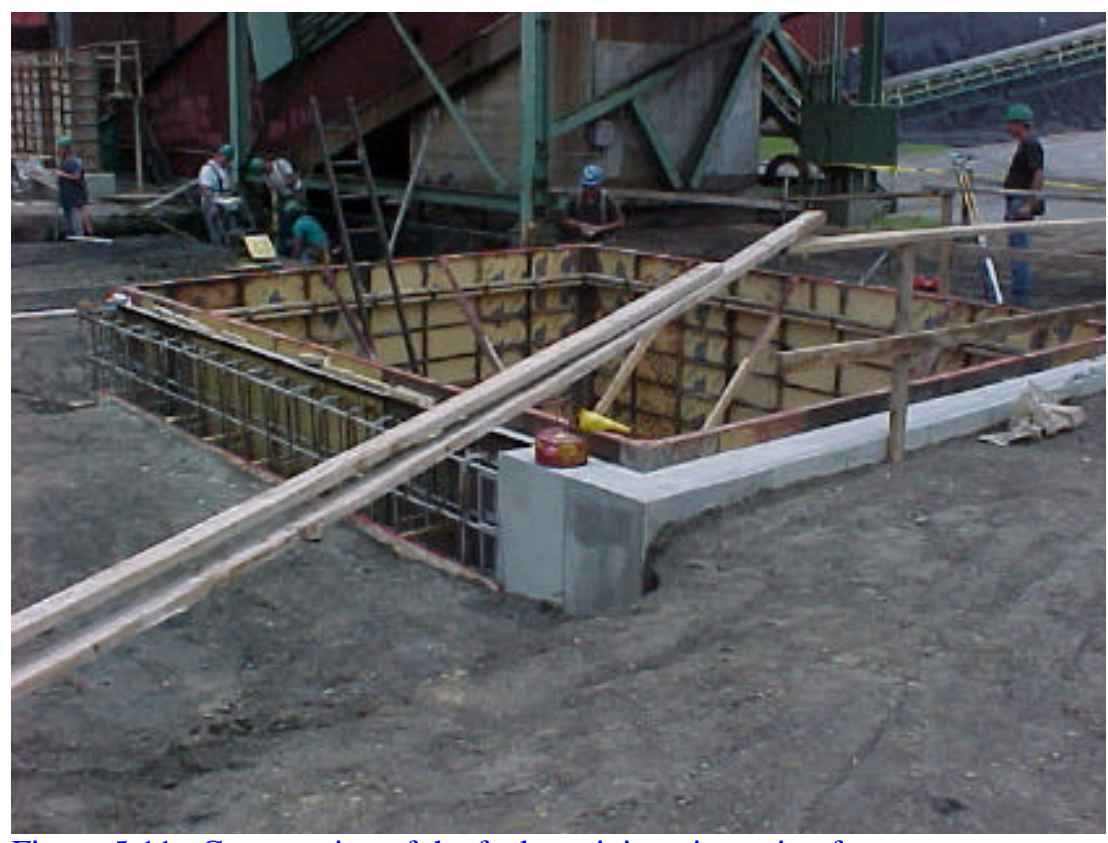

Figure 5-11. Construction of the fuel receiving pit, setting forms 


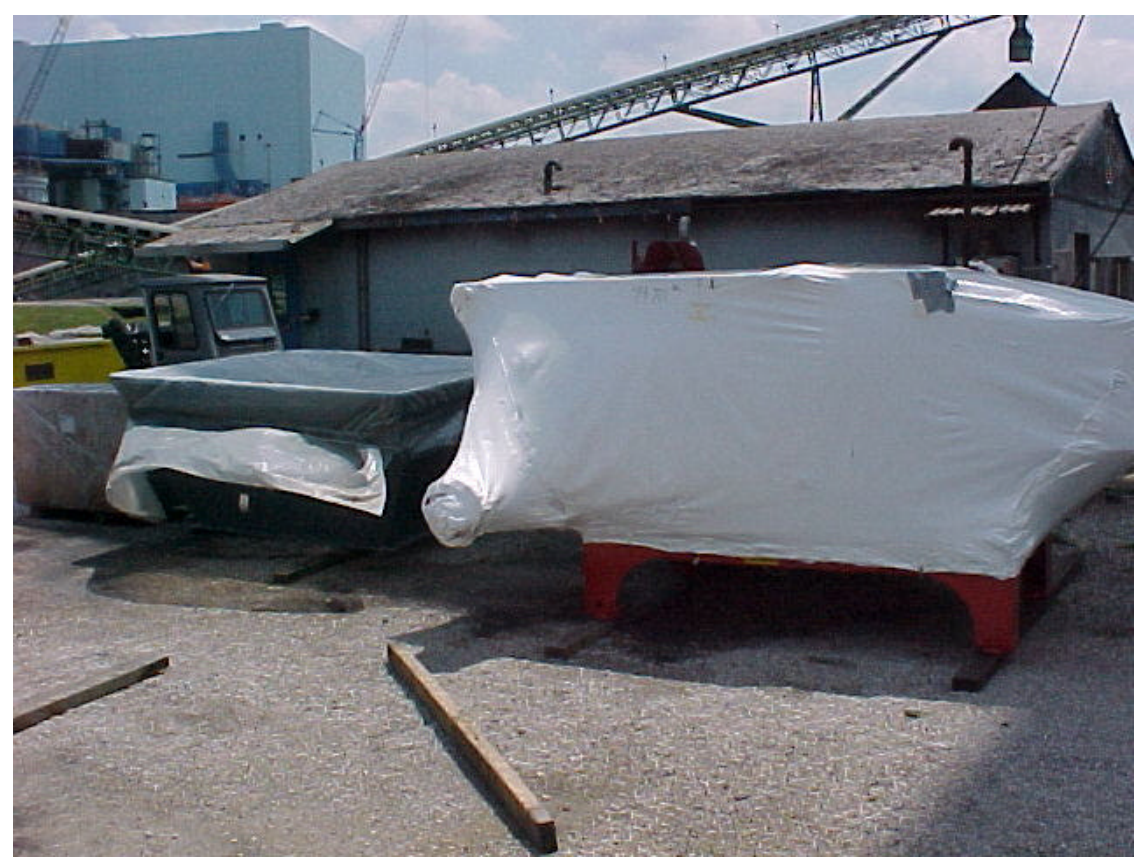

Figure 5-12. Laydown area for equipment to be installed including overs grinder

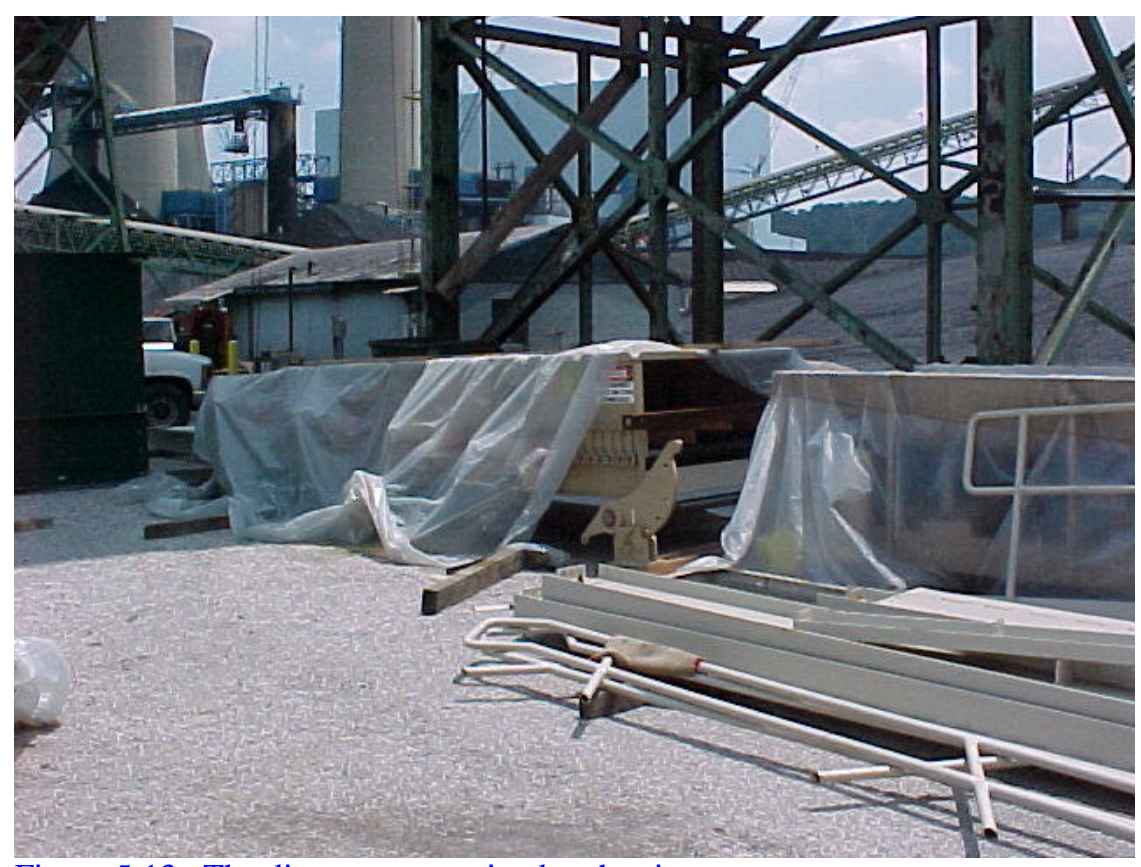

Figure 5-13. The disc screen received at the site 


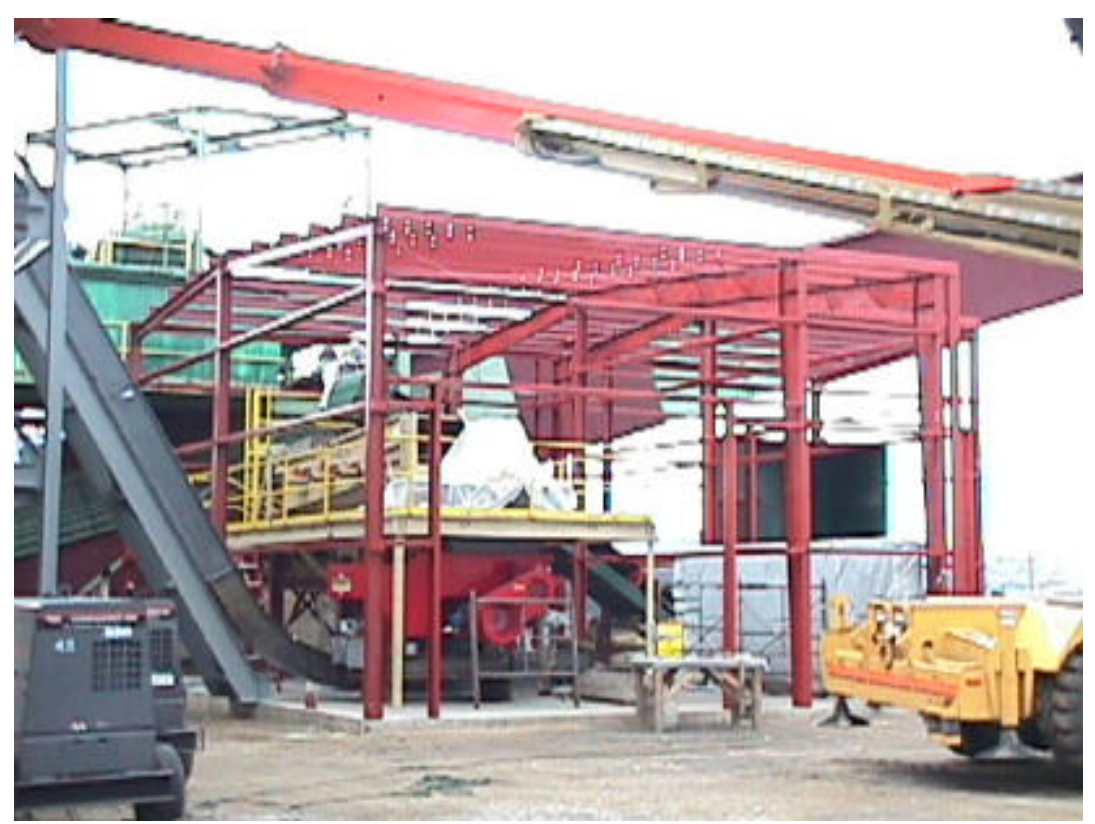

Figure 5-14. Construction of the processing facility including the disc screen, grinder, and outfeed conveyor

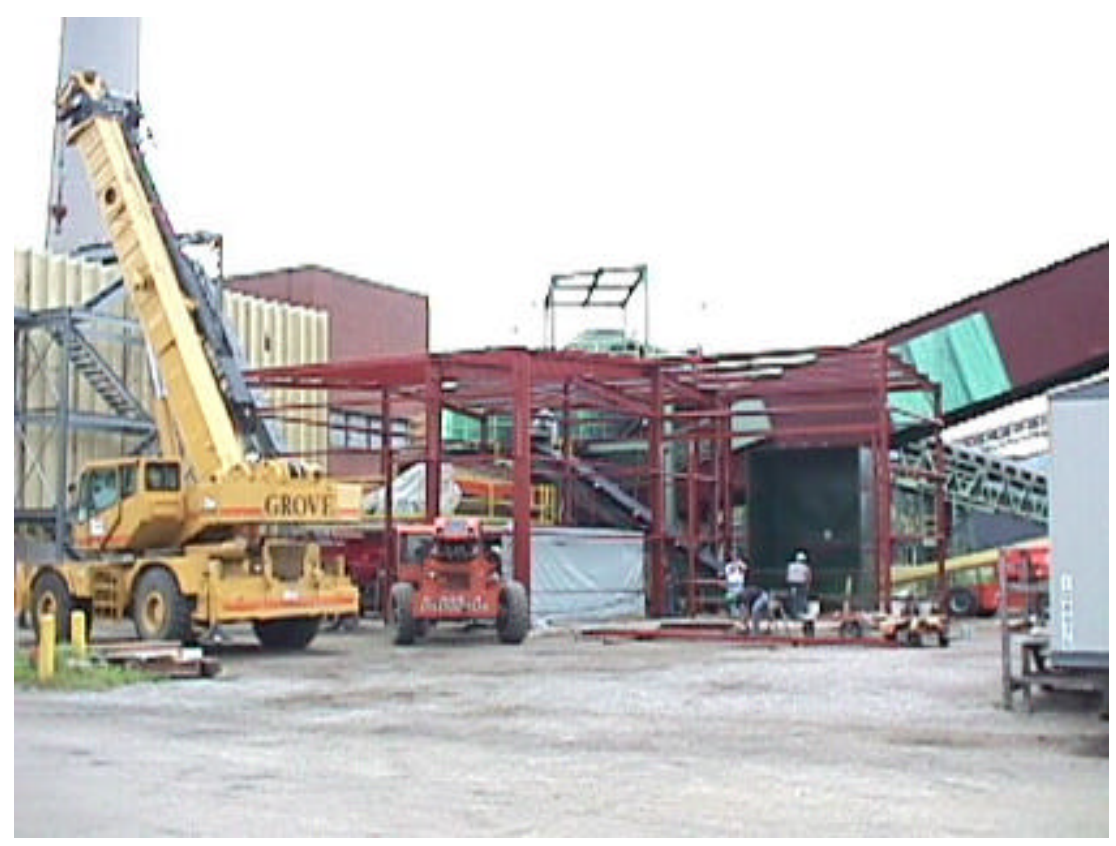

Figure 515. Construction of the processing facility including the sawdust receiving hopper 


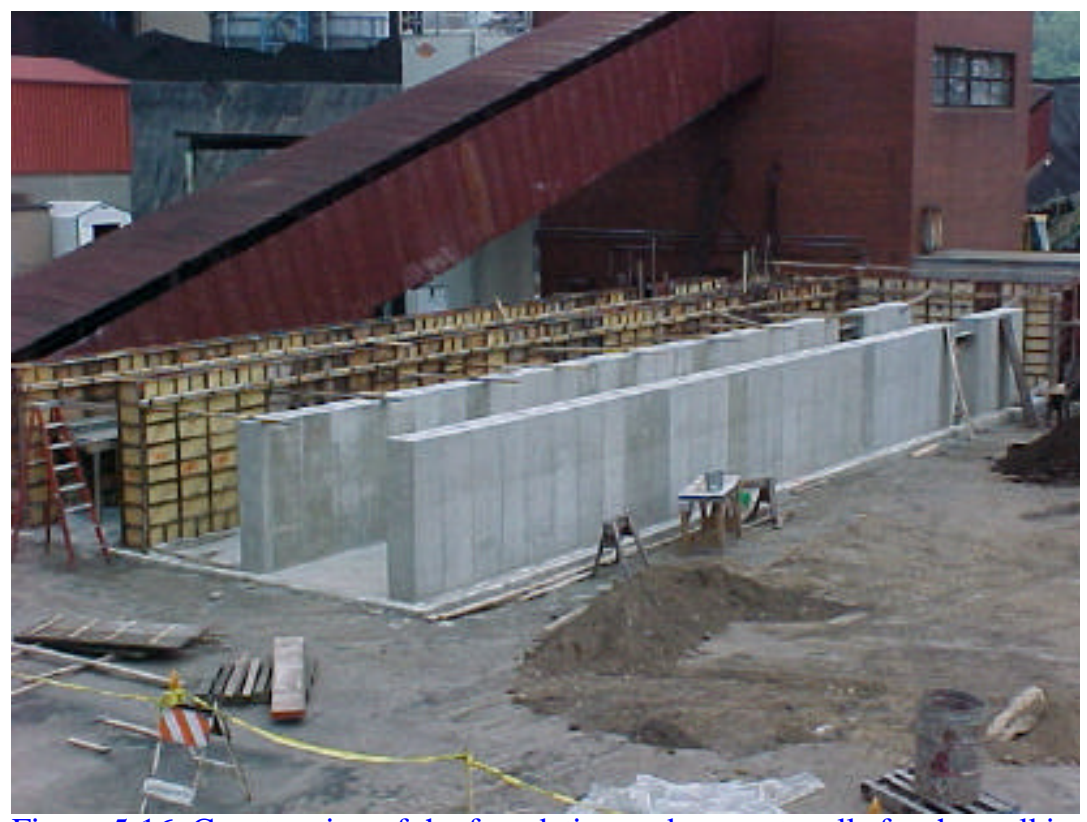

Figure 5-16. Construction of the foundation and support walls for the walking-floor bin

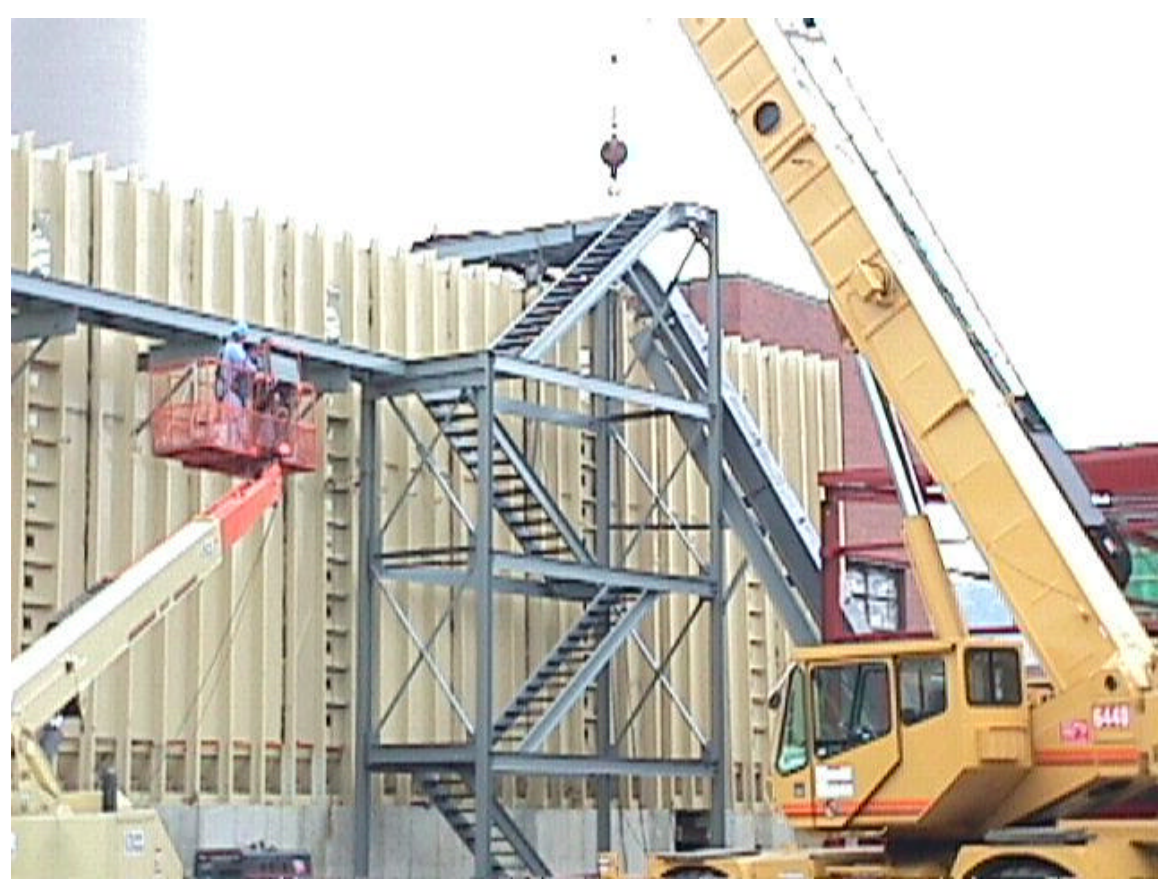

Figure 5-17. Construction of the walking floor bin 


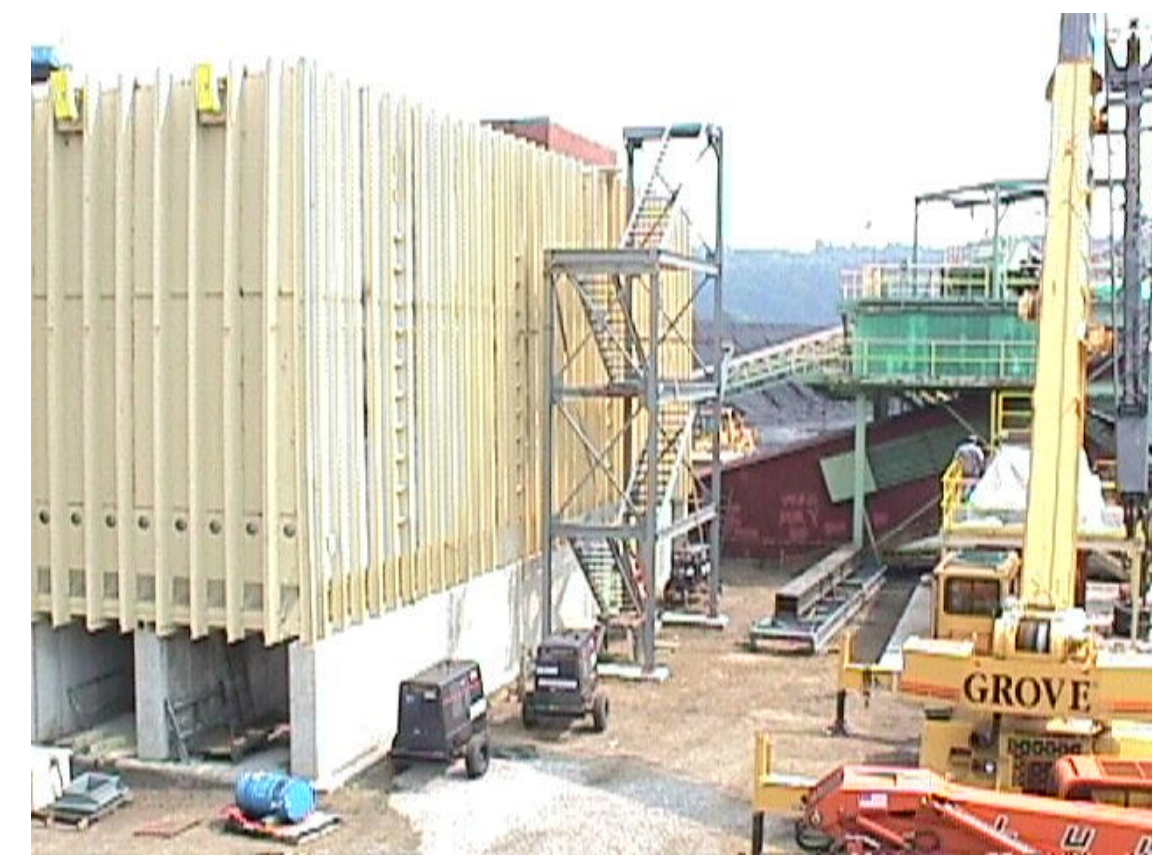

Figure 5-18. Construction of the walking floor bin walls

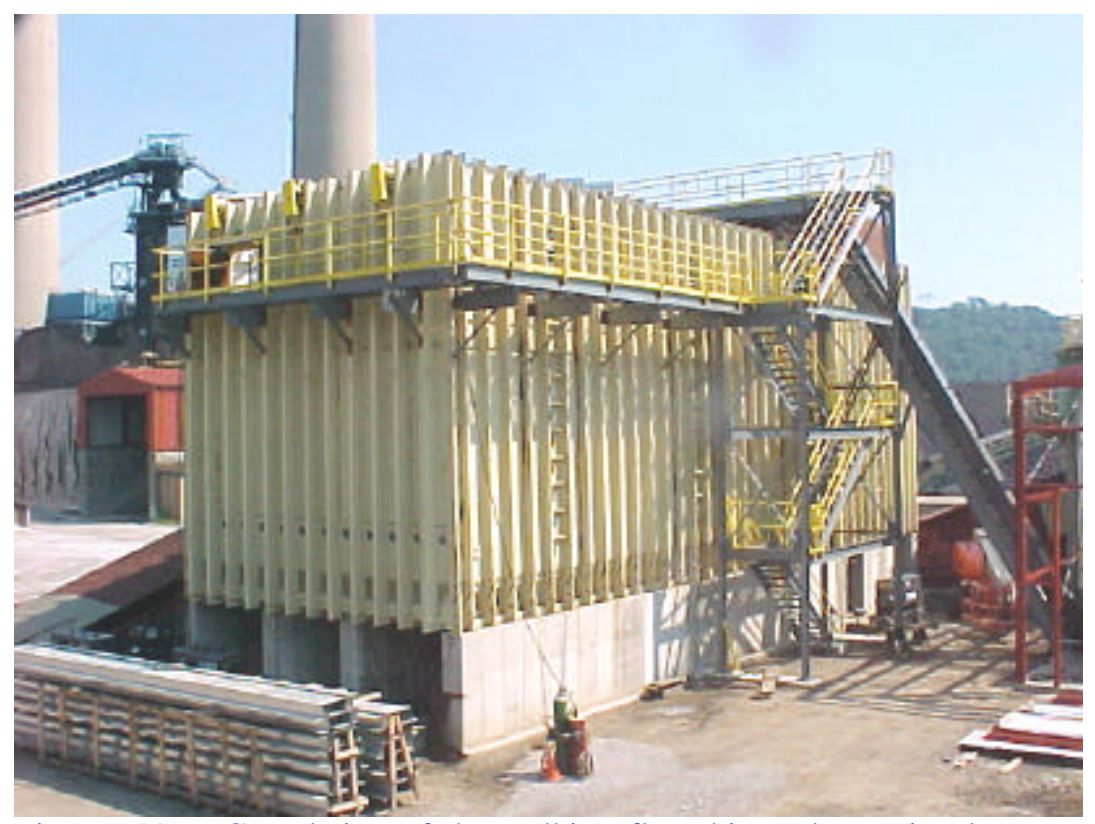

Figure 519. Completion of the walking floor bin and associated conveyor from the processing facility (under construction at extreme right) 


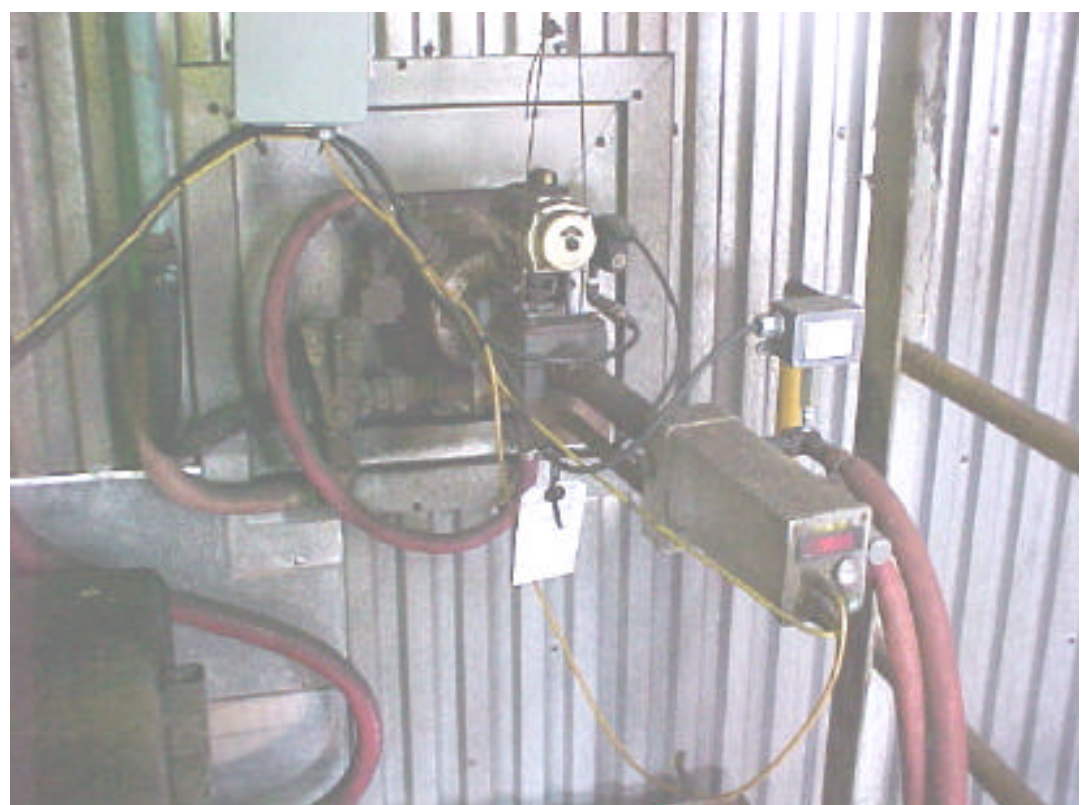

Figure 5-20. Furnace exit gas temperature probe installed at Willow Island Generating Station as part of the cofiring demonstration

Construction of the facility was completed during the year 2001, and the initial load of sawdust was received for start-up and shakedown in December, 2001. During shakedown numerous systems were modified, including the twin auger outfeed conveyor. Motor sizes were increased to meet the condition of the sawdust. Shakedown was completed during the second quarter of 2002, consistent with the plant outage. From that point cofiring testing commenced.

\subsubsection{Capital Cost of the System}

The major equipment for this system is identified in Table 5-2. The capital cost of this system is shown in Table 5-3. Note that the system was designed to supply a maximum of 15 percent of the mass flow of fuel to the boiler—or 7 percent of the heat input to the boiler. Consequently the system was designed to support generation of $13 \mathrm{MW}_{\mathrm{e}}$ (net) at this installation. The demonstration called for cofiring at a nominal 10 percent sawdust (mass basis), or support of $8.5 \mathrm{MW}_{\mathrm{e}}$ (net) of generation using biomass fuel. The TDF supported an additional $8-10 \mathrm{MW}_{\mathrm{e}}$ (net) of generation. 
Table 5-2. Major Equipment Installed at the Willow Island Cofiring Demonstration

\begin{tabular}{|c|l|l|}
\hline Number & \multicolumn{1}{|c|}{ Equipment Identification } & \multicolumn{1}{|c|}{ Notes } \\
\hline 1 & Walking floor bin & $\begin{array}{l}\text { Nominal capacity, 400 ton; actual } \\
\text { capacity 300 ton }\end{array}$ \\
\hline 2 & Disc screen & 50 ton $/ \mathrm{hr}$ to match truck unloading \\
\hline 3 & Outfeed conveyor from screen & 50 ton $/ \mathrm{hr}$ \\
\hline 4 & Sawdust receiving bin & 50 ton $/ \mathrm{hr}$ \\
\hline 5 & Belt conveyor to disc screen & 50 ton $/ \mathrm{hr}$ \\
6 & Grinder for screen rejects & $2.5 \mathrm{ton} / \mathrm{hr}$ (5\% of receipts) \\
\hline 7 & Cross feed conveyor to main coal & 75 ton $/ \mathrm{hr}$ \\
\hline 8 & belt & \\
\hline 9 & Weigh belt scale & \\
\hline 10 & hacuum system to facilitate & \\
\hline 11 & Fotor control center & \\
\hline
\end{tabular}

Table 5-3. Capital Cost of the Willow Island Cofiring Demonstration

\begin{tabular}{|l|l|l|}
\hline Number & Description & Capital Cost \\
\hline 1 & Process Equipment & \\
\hline & Walking floor bin & \\
\hline & Outfeed conveyor from bin & \\
& $\begin{array}{l}\text { Cross feed weigh belt conveyor } \\
\text { Scale }\end{array}$ & \\
\hline & Sawdust receiving hopper & \\
\hline & Conveyor to disc screen & \\
\hline & $\begin{array}{l}\text { Disc screen } \\
\text { Overs grinder }\end{array}$ & \\
\hline & Outfeed conveyor & $\$ 194,400$ \\
\hline & Vacuum system & $\$ 1,114,400$ \\
\hline & Motor control center & $\$ 86,800$ \\
\hline & Engineering Studies & $\$ 2,315,800$ \\
\hline & Soils Studies & \\
\hline 3 & Engineering & \\
\hline 4 & Construction & \\
\hline & Home Office Support and Other & \\
\hline & TOTAL & \\
\hline
\end{tabular}

Note that the capital cost allocation, beyond process equipment and construction, is somewhat arbitrary. Studies such as the CFD modeling are not included in this estimate. Other costs, including project management, are only partially allocated to the home office support cost. However, for capital cost estimation this provides a reasonable estimate of what could be considered the capital cost if one were to duplicate the installation on a commercial basis. 
Given the capital costs as shown in Table 5-3, the system is designed to be installed at a capital cost of $\$ 180 / \mathrm{kW}$ supported by biomass, assuming its use at 15 percent cofiring on a mass basis. As a practical matter, when used at 10 percent cofiring (mass basis) the capital cost is $\$ 270 / \mathrm{kW}$.

It is important to note that these capital costs are associated with a system that is reasonably automated, and that can be controlled from the fuels control room. Receiving of sawdust is the only activity that requires an individual to monitor; and that requirement will cease with the institutionalization of biomass fuel receipts from regular sources.

Lower cost systems can be constructed substituting operating and maintenance costs for capital costs. 


\subsection{Operational and Testing Results at Willow Island Generating Station}

Following the construction of the cofiring facility, and the scheduled outage of the plant, cofiring testing commenced. Baseline tests were conducted in August, 2001 and again in March, 2002. Intensive cofiring and opportunity fuel blend testing began in June of 2002 and continued intensively throughout that year. Testing continued intermittently throughout 2003, when demonstration proceeded. Operationally, in excess of 6,000 hours of cofiring were experienced at various levels of sawdust feeding to the boiler.

The pictures in Chapter 5 illustrate most of the system tested. The pictures presented below depict the key elements of the system in operation.

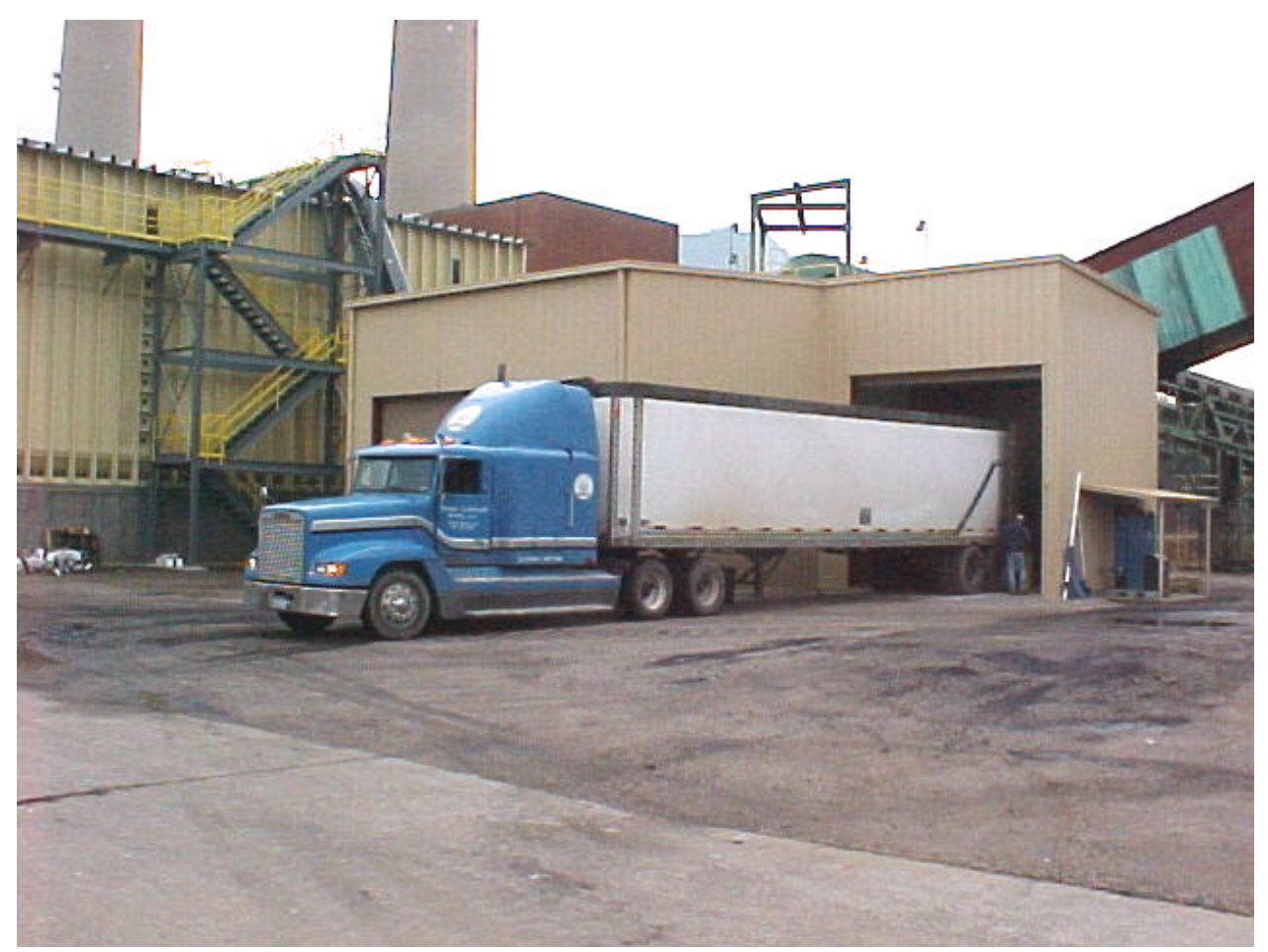

Figure 6-1. Receiving sawdust at the Willow Island demonstration site 


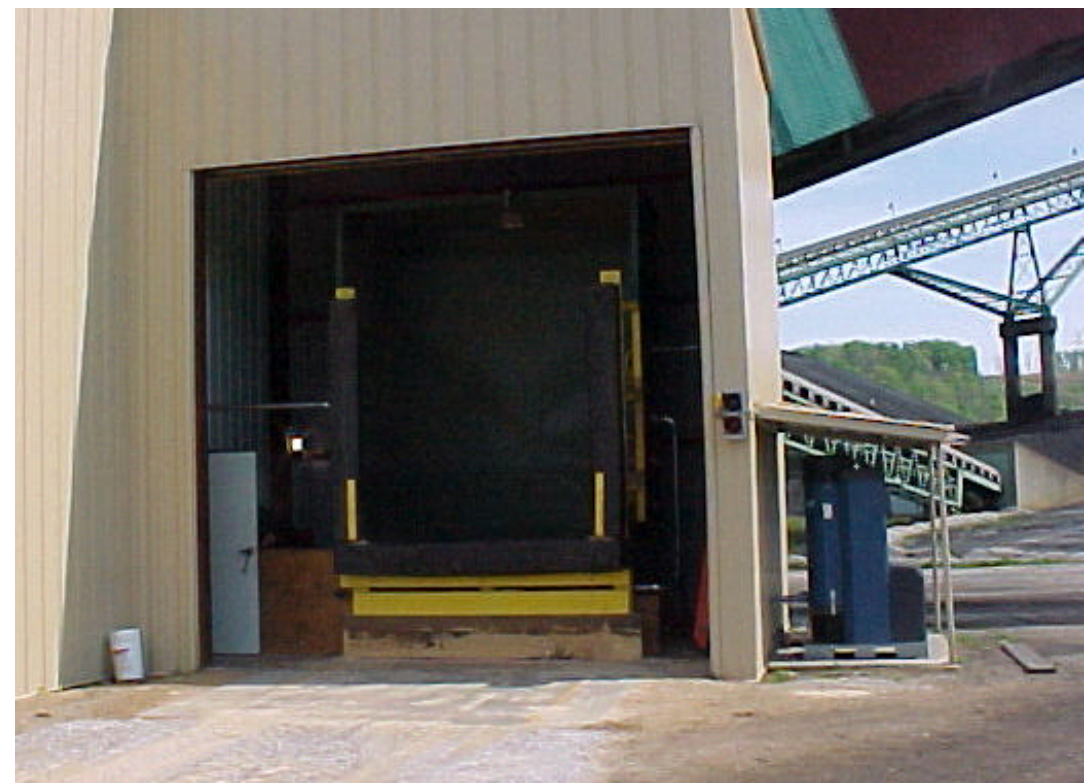

Figure 6-2. The sawdust receiving hopper and door. Note the vacuum system at the far right of the structure. This facilitates housekeeping and discharges captured sawdust in the receiving hopper

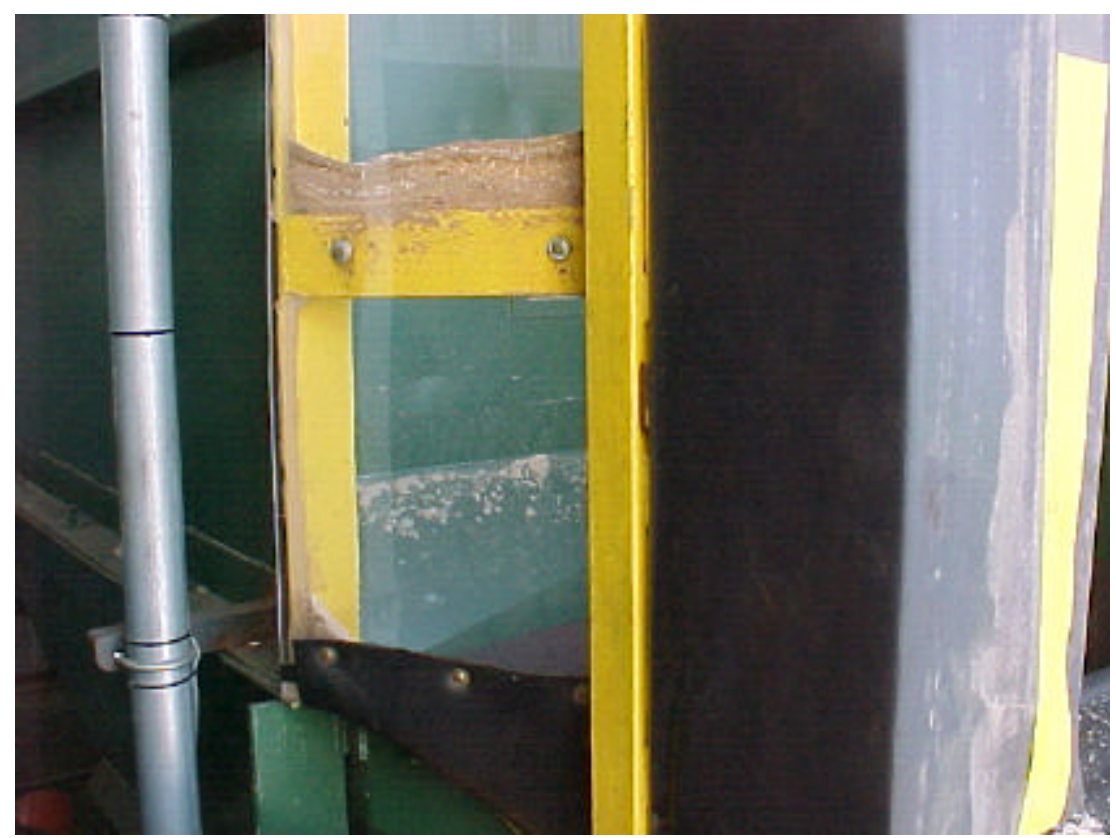

Figure 6-3. The plexiglass and rubber bumper structure at the sawdust receiving hopper, designed to minimize spillage 


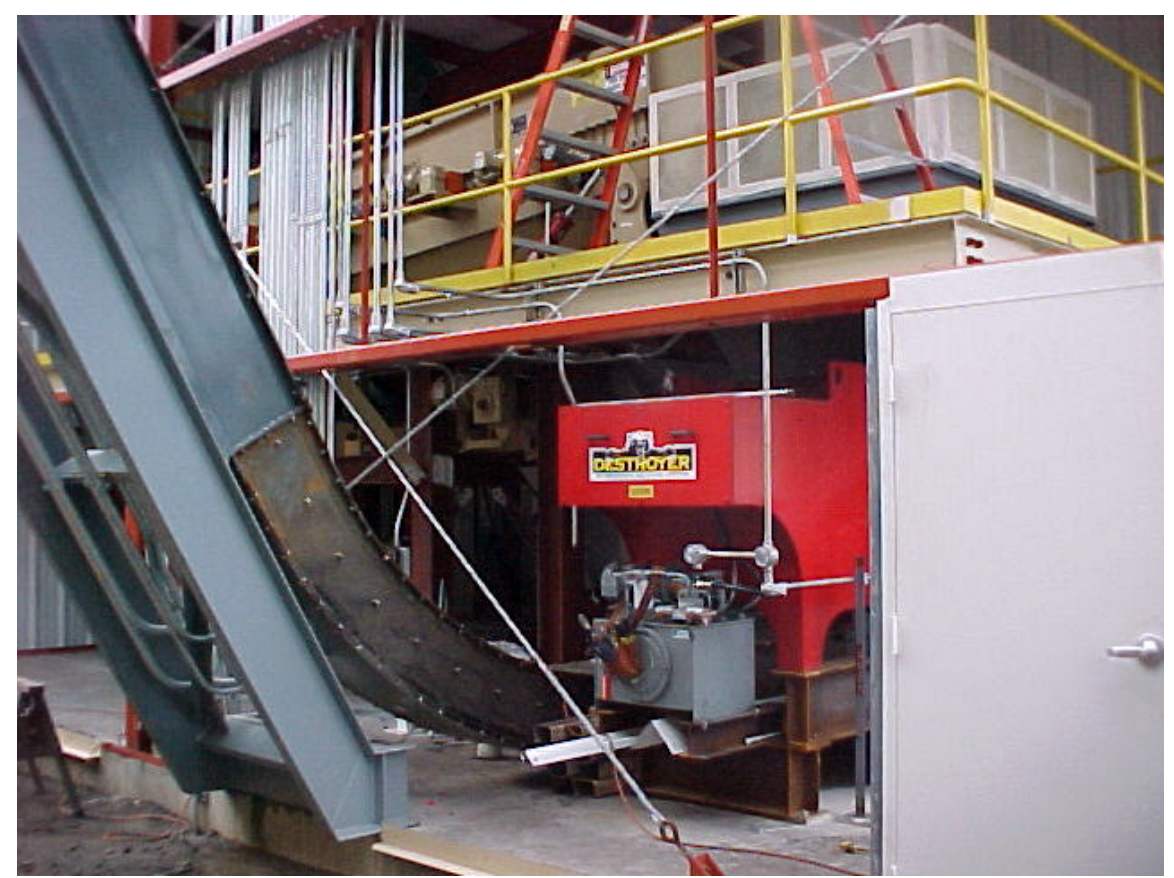

Figure 6-4. The disc screen and overs grinder discharge to the outfeed conveyor

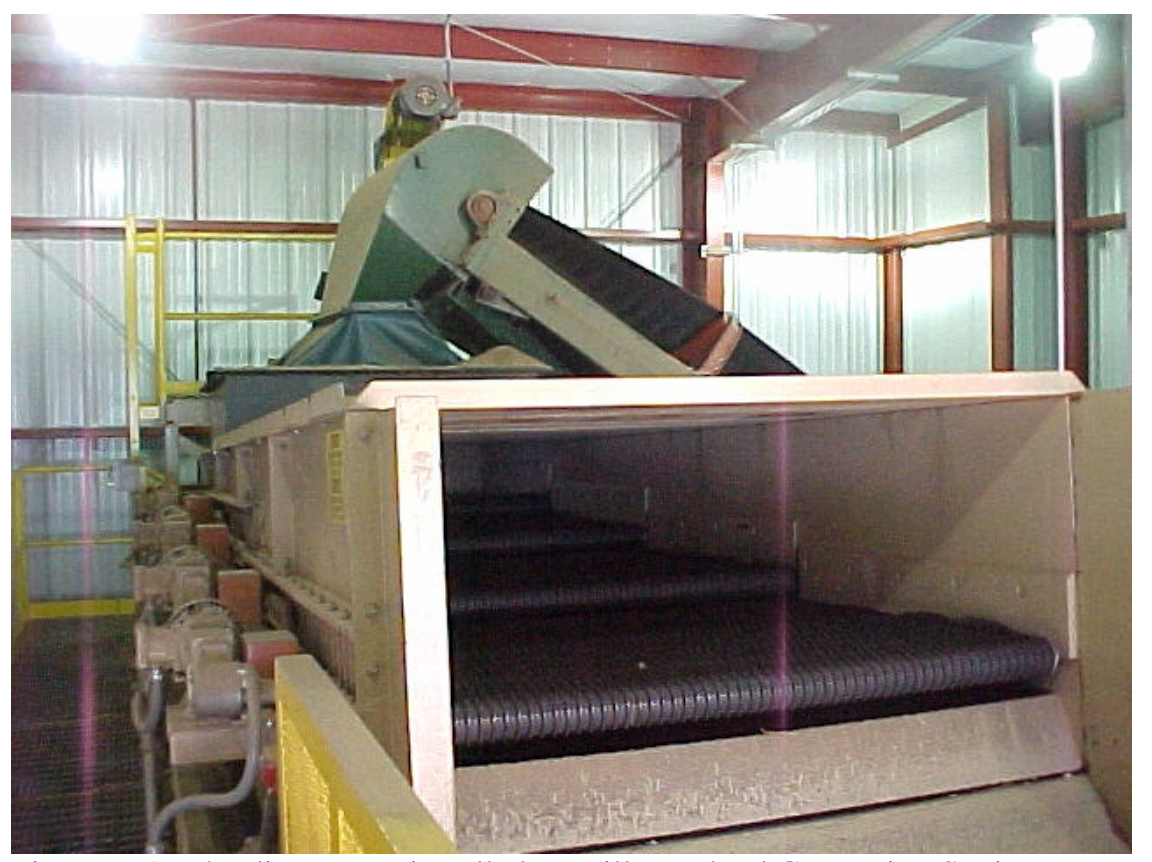

Figure 6-5. The disc screen installed at Willow Island Generating Station 


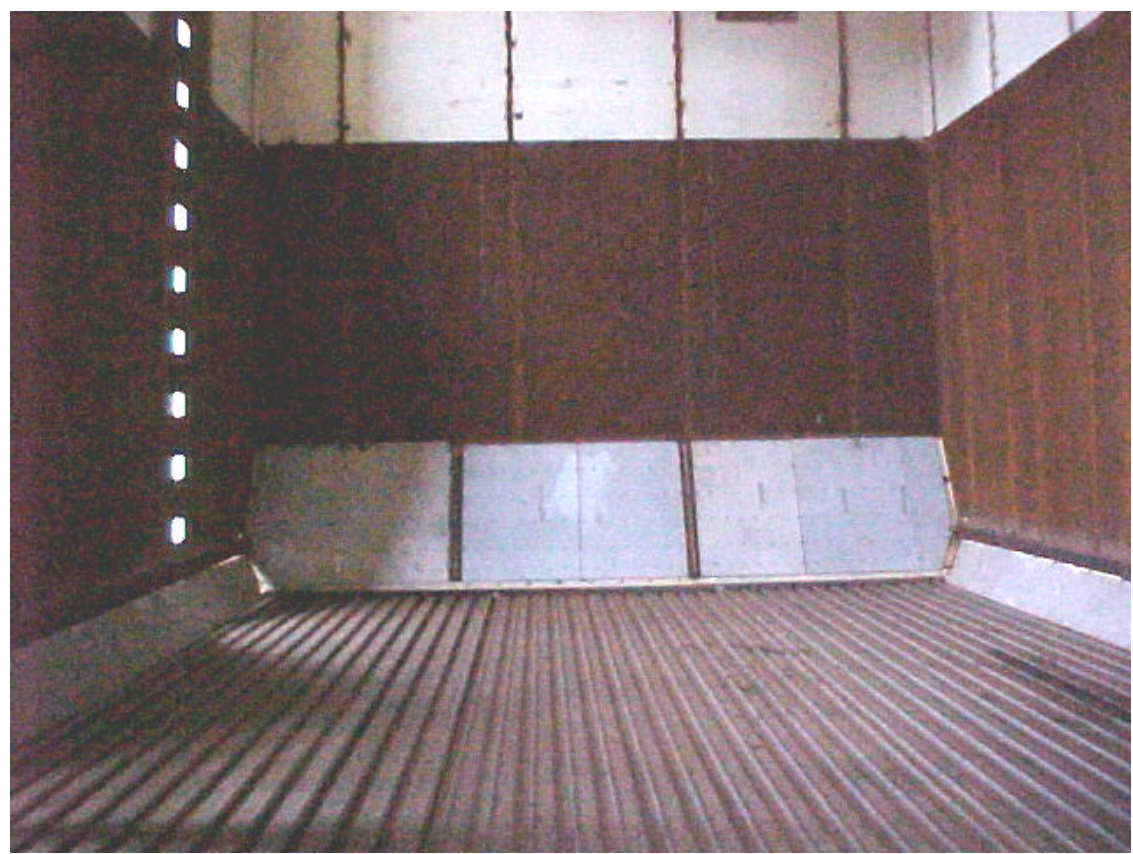

Figure 6-6. The inside of the walking floor bin

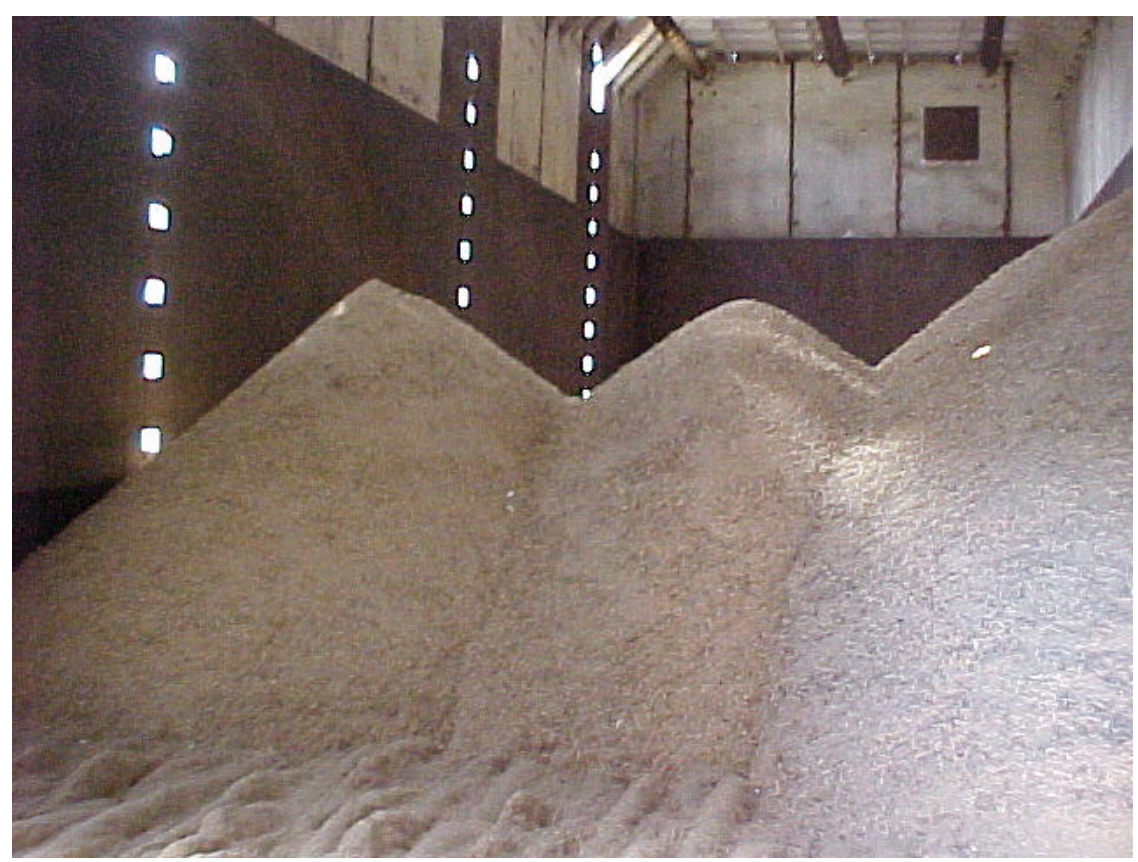

Figure 6-7. The walking floor bin receiving sawdust from the processing facility 


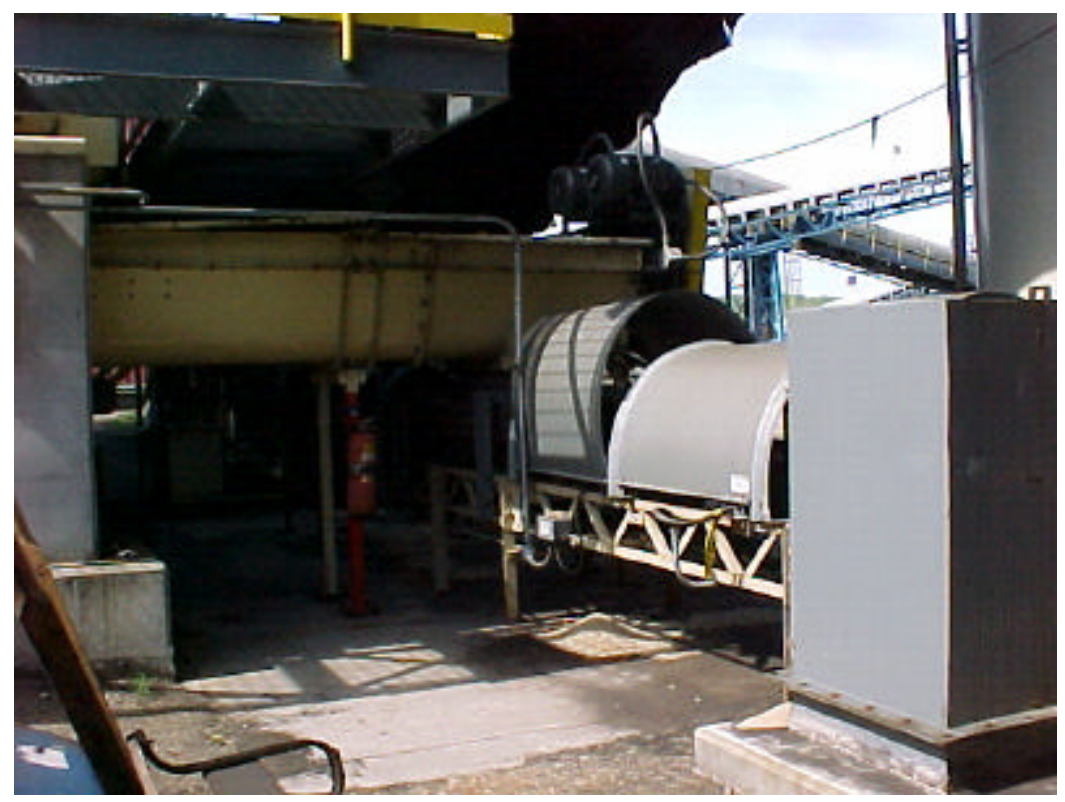

Figure 6-8. The discharge of the twin auger conveyor to the metering weigh belt conveyor at Willow Island Generating Station

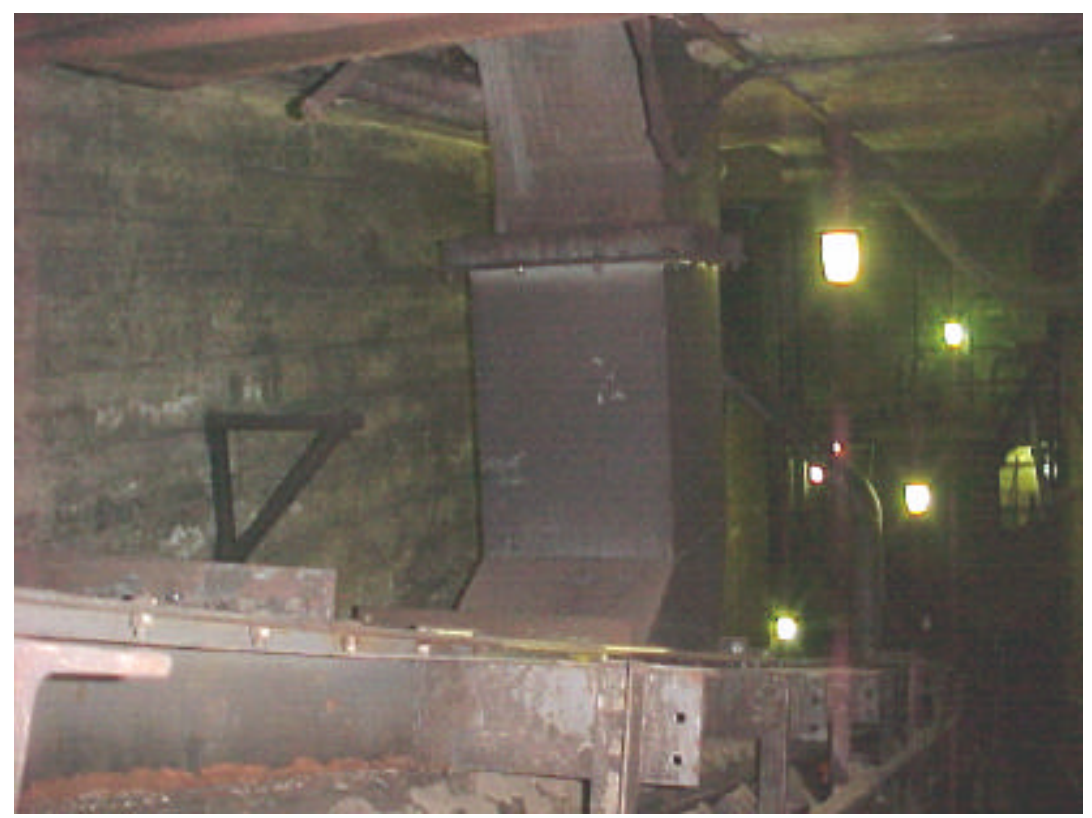

Figure 69. The discharge chute feeding sawdust onto the main conveyor at Willow Island Generating Station 


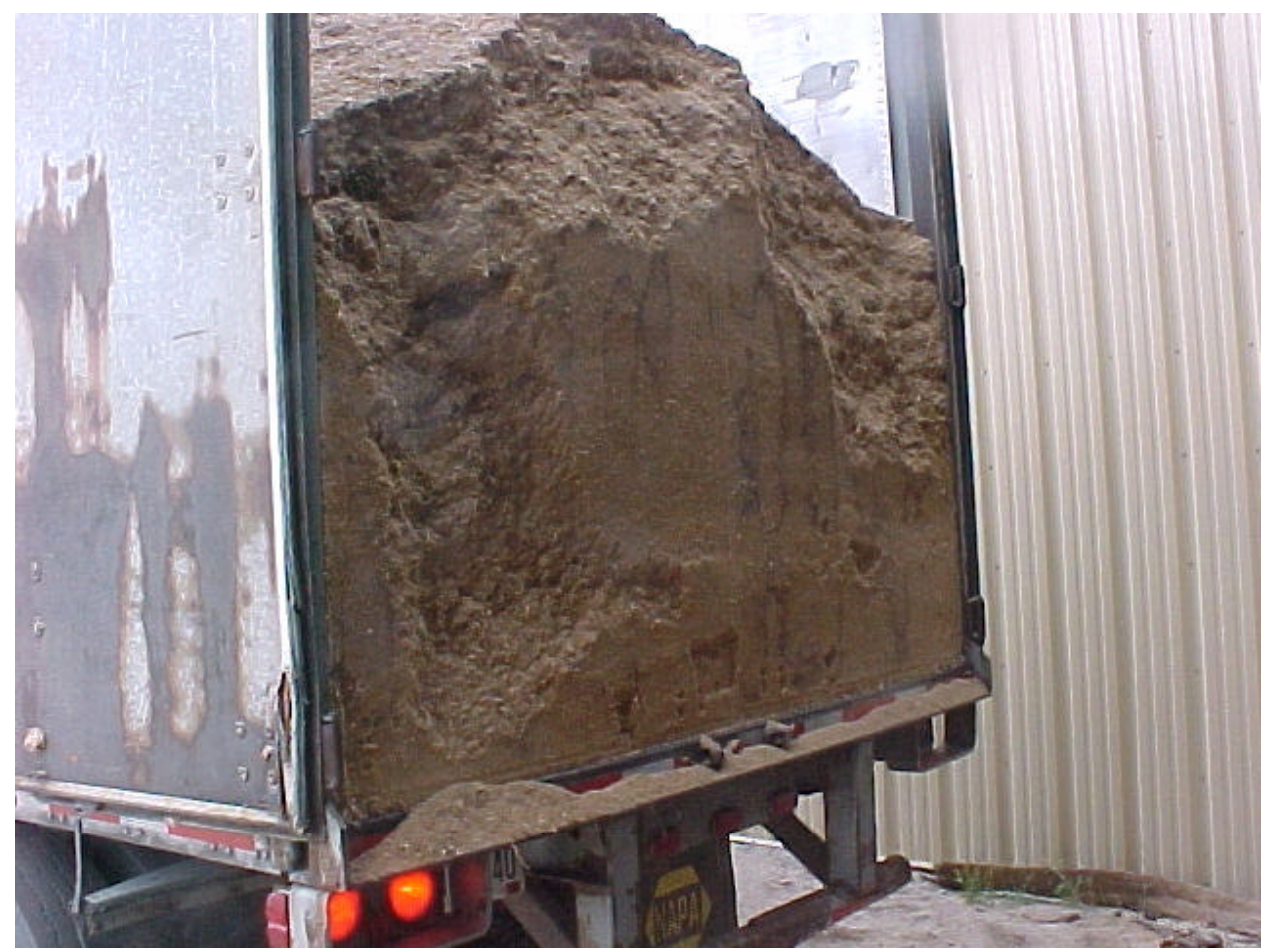

Figure 6-10. A load of sawdust being delivered to Willow Island Generating Station

\subsection{Test Program Parameters}

The test program was based upon extensive preliminary research including extensive fuel characterization, furnace modeling, and reviews of cofiring results at other test programs involving cyclone boilers: Bailly Generating Station of NIPSCO, Michigan City Generating Station of NIPSCO, and Allen Fossil Plant of TVA. The test resulting program developed for the Willow Island Generating Station involved evaluating both operational and environmental concerns. Operational issues included the following:

- The influence of cofiring on the ability of the Willow Island \#2 boiler to achieve capacity

- The impact of sawdust cofiring, and combined sawdust/TDF cofiring, on boiler efficiency-including an assessment of the influence of cofiring on the factors influencing boiler efficiency such as excess $\mathrm{O}_{2}$ or stoichiometric ratio, air heater exit temperature, and unburned carbon in the flyash or loss on ignition (LOI)

- The impact of sawdust cofiring, and combined sawdust/TDF cofiring, on net station heat rate (NSHR) expressed in Btu/kWh, including the critical concern of the influence of cofiring on main steam temperatures 
- The impact of sawdust cofiring, and combined sawdust/TDF cofiring, on flame temperatures and furnace exit gas temperatures (FEGT)

The environmental issues associated with the cofiring testing included the following:

- The influence of cofiring sawdust and combined sawdust/TDF on $\mathrm{NO}_{\mathrm{x}}$ emissions

- The influence of cofiring sawdust on mercury emissions

- The influence of cofiring sawdust on reductions of greenhouse gas (fossil $\mathrm{CO}_{2}$ equivalent) emissions

- The influence of cofiring sawdust, and the combination of sawdust and TDF, on CO emissions and opacity

The test program was designed not only to measure these influences but also to determine statistically significant trends, and to explain specific results as measured.

\subsection{Test Methodology}

During the period 2002 - 2003, Allegheny Energy fired over 6,500 tons of sawdust at the Willow Island Generating Station, along with over 10,000 tons of TDF. Some 4,000 tons of sawdust were fired during 2002, when the most intensive testing occurred. An additional 2,500+ tons were fired in 2003, during the demonstration phase. The sawdust cofired was more than any other USDOE-funded cofiring test program to date. It resulted in the generation of $7.4 \times 10^{6} \mathrm{kWh}$ of green-renewable-electricity.

During 2002, 55 test periods were conducted, when the boiler was operating in a condition facilitating the development of test data. These 55 test periods represent some 200 hours of operation. During 2003, an additional 25 test periods were conducted, representing another 100+ hours of testing. During these test hours, the basic test parameters were varied significantly as shown in Table 6-1.

Table 6-1 . Variability of Basic Test Parameters During the Willow Island Test Period

\begin{tabular}{|l|c|c|c|c|}
\hline & $\begin{array}{l}\text { Percent } \\
\text { Sawdust }\end{array}$ & Percent TDF & $\begin{array}{l}\text { Gross Load } \\
\left(\mathrm{MW}_{\mathrm{e}}\right)\end{array}$ & $\begin{array}{l}\text { Net Load } \\
\left(\mathrm{MW}_{\mathrm{e}}\right)\end{array}$ \\
\hline Average & 5 & 2 & 166.3 & 157.2 \\
\hline Minimum & 0 & 0 & 108.3 & 100.3 \\
\hline Maximum & 9 & 7 & 196.6 & 186.7 \\
\hline
\end{tabular}

These tests represent a broad range of conditions for evaluating the commercial implications of biomass cofiring and designer opportunity fuels in cyclone boilers. 


\subsubsection{Test Identification and Data Gathering}

The test methodology involved operating the boiler with normal operating procedures; no specific conditions were required of the operators. The tons of all fuels loaded to the bunkers were reported in the coal logs for all days. The coal logs determined what days were considered test days. As an operating assumption, if a particular blend of coal was loaded by 1200 hours on a given day, it was assumed that the blend-or reasonably close to the blend--would be in the boiler by 1800 hours on that day. The Willow Island bunkers, like most bunkers, rathole; and the material loaded at the top rapidly descends to the discharge system. To the greatest extent possible, periods of time analyzed were selected if a given blend was loaded into the bunkers on consecutive days. While this assumption leads to uncertainty in the data, it is necessary given the fact that the coal is flowed through the bunkers to the cyclones; separate injection is not possible. Further, given the operating conditions at the station and the uncertainties of fuel supply, it was not practical to hold a single blend for 5 days.

The basic methodology then involved leaving the unit in automatic generation control (AGC), and acquiring operating data during the entire time frame of the testing. Acquisition of the data was by computer program; electronic data were stored and retrieved as needed, consistent with the cofiring percentages reported in the coal logs. The retrieved data were then reviewed to determine periods of stable operating loads. Operating periods chosen were typically on the order of 2 hours with many being as long as 4 hours and one being over 8 hours.

\subsubsection{Operational Data Acquisition}

The operational data acquired were those associated with constructing heat and material balances. Specific data included the following:

- Feedwater pressure, temperature, and flow

- Main steam pressure, temperature, and flow

- Cold reheat steam pressure and temperature

- Hot reheat steam pressure, temperature, and flow

- Reheat attemperation pressure, temperature, and flow

- Excess $\mathrm{O}_{2}$ at the furnace

- Excess $\mathrm{O}_{2}$ at the air heater exit

- Temperatures of the flue gas exiting the economizer and exiting the air heater

- Temperatures of the ambient air, air entering the air heater, and air exiting the air heater

- FEGT

- Coal feeder speeds (percentage basis)

Certain assumptions were made to augment these data. Cold reheat flow was assumed to be equal to hot reheat flow minus reheat attemperation flow. The temperature of the flue 
gas entering the air heater was assumed to be equal to the temperature of the gas exiting the economizer minus $28^{\circ} \mathrm{C}\left(50^{\circ} \mathrm{F}\right)$. This correction is the assumed temperature loss in the hot-side ESP. During low load conditions, the reheat steam flows reported by the control system are typically higher than the main steam flows. In these cases, the hot reheat steam flow was assumed to be 89.6 percent of the main steam flow; this assumption was based upon an analysis of the boiler heat balance drawing.

Because FEGT was considered a critical parameter, a Diamond Power Gastemp ${ }^{\mathrm{TM}}$ probe was purchased and installed at the nose of the boiler. The Gastemp ${ }^{\mathrm{TM}}$ probe was then connected to the Bailly control system for continuous recording of FEGT data.

In addition to the acquisition of continuous operating data, the analyses were based upon extensive characterization of the sawdust, coal, and TDF burned at the Willow Island Generating Station. These characterizations were performed at the beginning of the program. Bottom ash (slag) unburned carbon was assumed to be almost $0-0.15$ percent. Unburned carbon in the flyash was based upon the LOI measurements for the week during the test period. Since flyash contains only 30 percent of the solid products of combustion from cyclone firing, and since the LOI values were reasonable in all cases, this parameter was not extensively analyzed. Feedwater and steam enthalpies were calculated using the ASME Steam Properties software.

\subsubsection{Environmental Data Acquisition}

Once the test period was determined, Certified Emissions Monitoring System (CEMS) data were obtained consistent with the test period. The CEMS data obtained were as follows:

- $\mathrm{NO}_{\mathrm{x}}, \mathrm{ppmv}$

- $\mathrm{NO}_{\mathrm{x}}, \mathrm{lb} / 10^{6} \mathrm{Btu}$

- $\mathrm{SO}_{2}, \mathrm{ppmv}$

- $\mathrm{SO}_{2}, \mathrm{lb} / 10^{6} \mathrm{Btu}$

- $\mathrm{CO}$

- Opacity

- Load

It was recognized that $\mathrm{NO}_{\mathrm{x}}$ values reported from the CEMS as $1 \mathrm{~b} / 10^{6}$ Btu are based upon an F-Factor, obtained from USEPA literature and installed in the monitoring equipment. It was also recognized that the F-Factor is based upon the ultimate analysis of the fuel as fired, and the most precise F-Factor is calculated for each blend. F-Factors for lower rank fuels are lower than those for higher rank coals; consequently blends of coal and sawdust can have lower F-Factors than the coal alone. When using CEMSdata, this can result in overstating the $\mathrm{NO}_{\mathrm{x}}$ and $\mathrm{SO}_{2}$ emissions. In order to determine whether the $\mathrm{F}$ Factor would unduly bias results upward when cofiring sawdust with coal, F-Factors were calculated for the coal alone, and for all coal/sawdust/TDF blends. Using the $\mathrm{O}_{2}$ based F-Factor calculation, an operational equation for corrections was developed: 
Where $\mathrm{F}_{\mathrm{WI}}$ is the F-Factor for Willow Island coal, $\% \mathrm{C}$ is the mass percent coal in the fuel blend, $\% \mathrm{~W}$ is the mass percent sawdust in the fuel blend, and \% TDF is the mass percent TDF in the fuel blend. This is an operational equation only; its parameters have no fundamental basis. However the equation shows that the sawdust and the TDF both have the potential to reduce the F-Factor used to calculate $\mathrm{NO}_{\mathrm{x}}$ and $\mathrm{SO}_{2}$ emissions in $\mathrm{lb} / 10^{6}$

Btu. Given equation [1], the $\mathrm{NO}_{\mathrm{x}}$ emissions reported by the CEMS were adjusted for the specific fuel blend and then compared to the original values reported by the CEMS. The results of this comparison are shown in Figure 6-11. Note that there is almost no correction associated with the fuel-specific FFactors. On this basis the CEMS data are used directly throughout the remainder of this report.

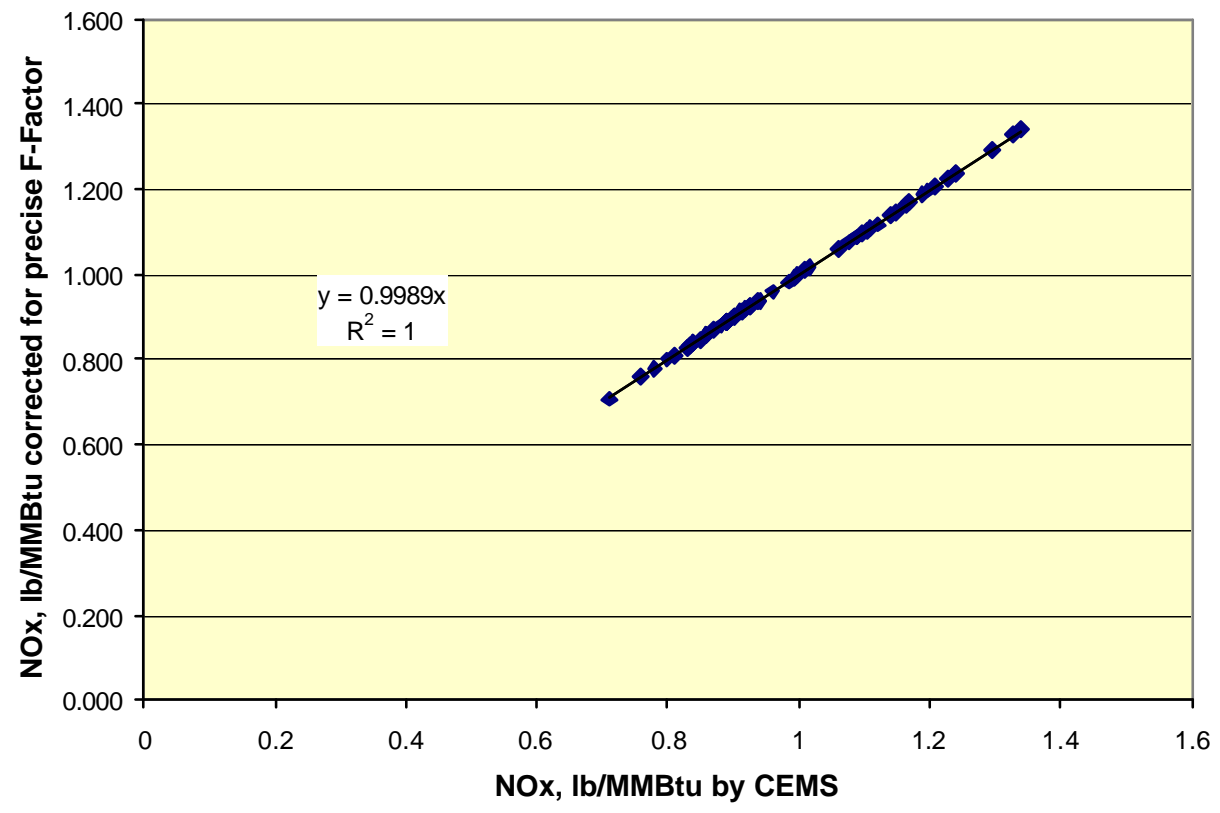

Figure 6-11. Comparison of $\mathrm{NO}_{\mathrm{x}}$ Reported by the CEMS, and $\mathrm{NO}_{\mathrm{x}}$ Reported, and Corrected for Fuel-Specific F-Factors

Fossil $\mathrm{CO}_{2}$ emission reductions were analyzed based upon the tons of sawdust fired. Mercury emissions were analyzed based upon a comparison of the sawdust with reports to USEPA by Allegheny Energy.

\subsection{Analytical Techniques}

The data were then analyzed by constructing a series of simplified heat and material balances about the Willow Island \#2 boiler. These balances were integrated with the 
CEMS data to depict the emissions simultaneously with the operating data. Note that the percentage sawdust and TDF shown in the heat balances is on a heat input basis.

In addition to the heat and material balances, theoretical flame temperatures were calculated using CET-89, the thermodynamic combustion code developed by NASA and used widely throughout the combustion industry. Theoretical flame temperatures were calculated, in absolute temperatures, based upon the analysis of the fuel blend, the stoichiometric ratio, and the temperature of the air exiting the air heater. The estimate of actual flame temperature within the cyclone barrel was taken to be 90 percent of the theoretical flame temperature on an absolute basis. This estimate is consistent with cyclone firing literature, and consistent with measurements made at both the Allen Fossil Plant and Paradise Fossil Plant of TVA during extended combustion tests. Additional cyclone modeling was performed using a Foster Wheeler simplified model to evaluate additional issues.

Once the basic analyses were performed, trends in the data were then evaluated using statistical analysis, focusing upon regression analysis and curve fitting. In this way, the influences of cofiring could be readily depicted.

\subsection{Operational Results from cofiring at Willow island}

Operational results from cofiring sawdust, and combinations of sawdust and TDF, included the influences of these fuels on the ability of the unit to make capacity, to operate in an efficient manner, to achieve desired temperatures, and to impact fuel costs. In all of these cases the cofiring system met or exceeded expectations. These results have been discussed extensively (see Holt, 2003; Tillman, Payette, and Banfield, 2003).

\subsubsection{Impact of Cofiring on System Capacity}

As expected, the cofiring of sawdust modestly increased the use of boiler feeder capacity as is shown in Figure 6-12. The sawdust, having both a lower calorific value, and a lower bulk density, speeds up the feeders to the cyclones. However the increases in feeder speeds never caused the unit to experience a capacity limitation. The scatter in the data shown in Figure 6-12 reflect the influences of other operating conditions including such factors as load, excess $\mathrm{O}_{2}$, and percent TDF.

Because the fuel feeding capacity is a function of both fuel quality $\left(\mathrm{Btu} / \mathrm{m}^{3}\right.$ or Btu/ft $\mathrm{ft}^{3}$ of fuel) and load, a simplified regression equation was created as shown below:

$\mathrm{CF}=2.281+0.505(\% \mathrm{~W})+0.462\left(\mathrm{MW}_{\mathrm{g}}\right)$

Where $\mathrm{CF}$ is percentage coal flow, $\% \mathrm{~W}$ is percent sawdust cofiring on a mass basis, and $\mathrm{MW}_{\mathrm{g}}$ is the load expressed in gross megawatts generated. The coefficient of determination $\left(r^{2}\right)$ for this equation is 0.96 . The probability that the $\% \mathrm{~W}$ term occurs randomly is 0.00014 and the probability that the influence of load occurs randomly is $6.2 \times 10^{-40}$. 


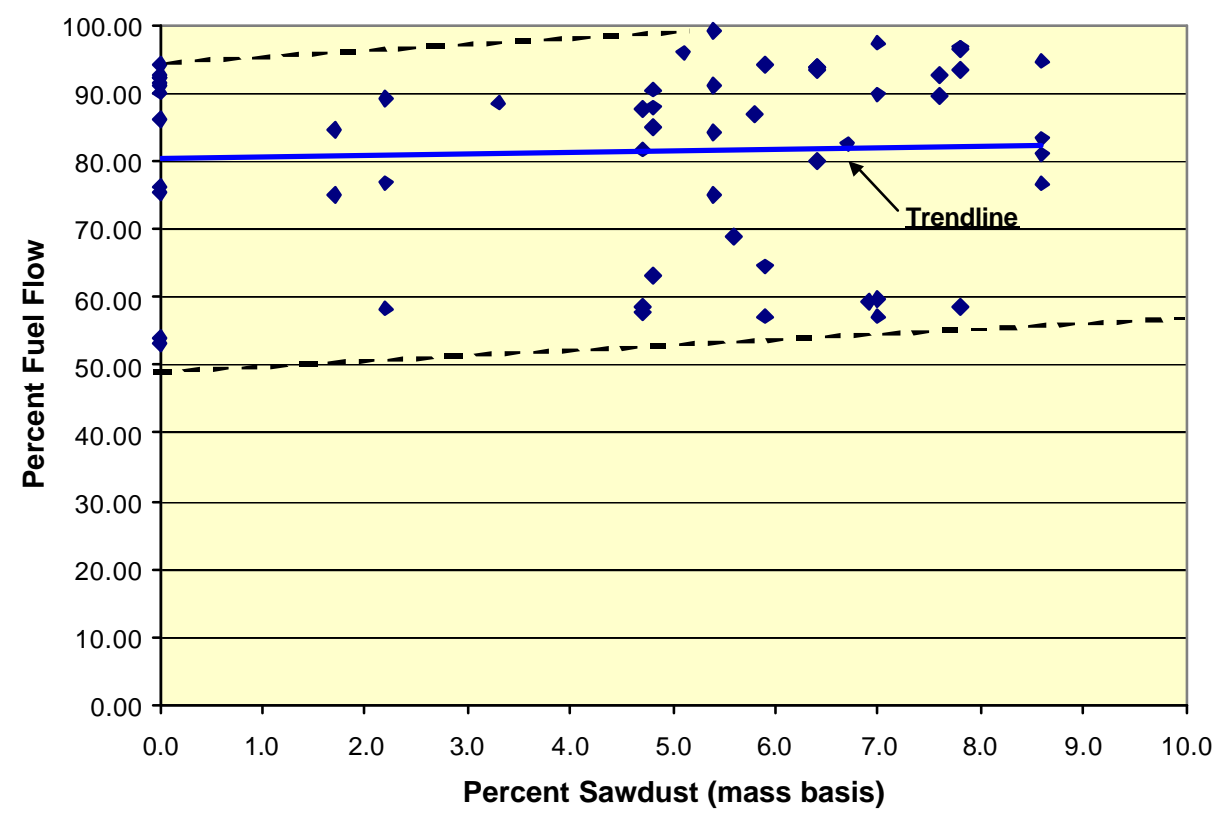

Figure 6-12. The Influence of Sawdust Cofiring on Fuel Feeding Capacity

\subsubsection{Impact of Cofiring on System Efficiency}

The impact of cofiring on system efficiency includes both boiler efficiency, expressed as a percentage, and net station heat rate expressed as Btu/kWh. Evaluations of efficiency include both assessments of specific operating parameters-excess $\mathrm{O}_{2}$ or stoichiometric ratio, air heater exit temperature, and loss on ignition-and on efficiency as a whole.

The overall influence of sawdust cofiring, and sawdust/TDF cofiring, on boiler efficiency is very small. An overall equation can be posited as follows:

$\eta=\mathrm{K}-0.029(\% \mathrm{~W})-0.026(\% \mathrm{TDF})$

Where $\eta$ is boiler efficiency expressed as a percentage; $\mathrm{K}$ is boiler efficiency when firing coal alone, $\% \mathrm{~W}$ is percent sawdust cofired, expressed on a mass basis; and \% TDF is percent tire-derived fuel cofired, expressed on a mass basis. Efficiencies as a function of fuel flow and load, alone, were not readily analyzed by statistics alone.

Boiler efficiency was evaluated by calculating a heat and material balance about the boiler for each test. Heat and material balances were calculated using molar calculations and the "losses" methodology. The overall influence of sawdust cofiring, and sawdust/TDF cofiring, on boiler efficiency is very small. Regression analysis shows that 
the maximum degradation in boiler efficiency caused by cofiring is 0.03 percent efficiency loss/percent wood cofiring on a mass basis. When cofiring at 10 percent (mass basis) the maximum efficiency loss would be 0.3 percent. Figure 613 depicts the heat and material balance schematic employed for this analysis.

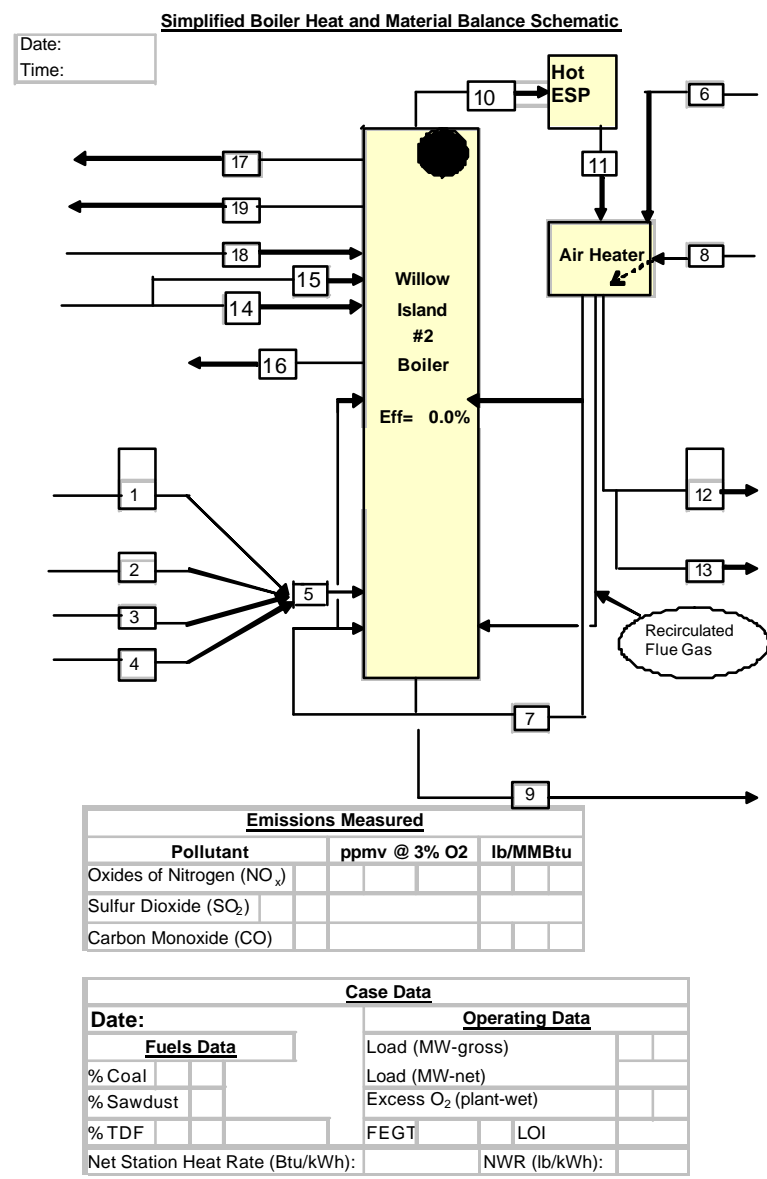

\begin{tabular}{|c|c|c|c|c|}
\hline \\
\hline \multirow{2}{*}{\multicolumn{2}{|c|}{ No Descriptor }} & Mass & Pressure & Iemp \\
\hline & & (kpph) & (psig) & (F) \\
\hline \multicolumn{5}{|c|}{1 Coal } \\
\hline \multicolumn{5}{|c|}{2 TDF } \\
\hline \multicolumn{5}{|c|}{3 Sawdust } \\
\hline \multicolumn{5}{|c|}{4 Limestone } \\
\hline \multirow{2}{*}{\multicolumn{5}{|c|}{ 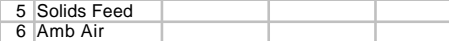 }} \\
\hline & & & & \\
\hline \multicolumn{5}{|c|}{7 Heated Air } \\
\hline \multicolumn{5}{|c|}{8 Inleak Air } \\
\hline \multicolumn{5}{|c|}{9 Slag } \\
\hline \multicolumn{5}{|c|}{10 Flue Gas } \\
\hline \multicolumn{5}{|c|}{11 Flue Gas } \\
\hline 12 & \multicolumn{4}{|l|}{ Flue Gas } \\
\hline \multicolumn{5}{|c|}{13 Flyash } \\
\hline \multicolumn{5}{|c|}{14 Boiler Fwater } \\
\hline \multicolumn{5}{|c|}{15 Reheat Attemp } \\
\hline \multicolumn{5}{|c|}{16 SB \& Bldown } \\
\hline \multicolumn{5}{|c|}{17 Main Steam } \\
\hline \multicolumn{5}{|c|}{18 Cold Reheat } \\
\hline \multicolumn{5}{|c|}{19 Hot Reheat } \\
\hline \multicolumn{5}{|c|}{ Heat Balance About Boiler } \\
\hline \multicolumn{3}{|c|}{ Parameter } & MMBtu & Percent \\
\hline \multicolumn{5}{|c|}{ Inputs } \\
\hline \multicolumn{5}{|c|}{ Coal } \\
\hline & \multicolumn{4}{|l|}{ Sawdust } \\
\hline \multicolumn{5}{|c|}{ TDF } \\
\hline & & & & \\
\hline & Total Fuel & & & \\
\hline & Air & & & \\
\hline & sses & & & \\
\hline & Dry Gas Loss & & & \\
\hline & Moisture in Fuel & & & \\
\hline & Hydrogen in Fuel & & & \\
\hline & Moisture in Air & & & \\
\hline & ESP Losses & & & \\
\hline & Flyash & & & \\
\hline & Slag & & & \\
\hline & Fixed Losses & & & \\
\hline Usef & ful Heat as Stea & & & \\
\hline
\end{tabular}

Figure 6-13. Schematic for heat and material balance calculations employed at Willow Island Generating Station demonstration

The influence of specific parameters on efficiency became of significance for analytical purposes. Factors analyzed included excess $\mathrm{O}_{2}$ or stoichiometric ratio, air heater exit temperature, loss on ignition, and then selected components of the losses calculation: dry gas loss, fuel moisture content, and hydrogen content in the fuel.

Excess $\mathrm{O}_{2}$ at the furnace exit, or stoichiometric ratio (SR) for combustion, was the first variable analyzed. The use of excess air as a function of fuel was again analyzed by regression analysis. A specific function was created showing that the SR decreased by 
$1.6 \times 10^{-5}$ for every percent wood cofired in the fuel blend. The SR decreased by 0.0005

for every percent TDF in the fuel blend. The $\mathrm{r}^{2}$ for the equation created is 0.81 , and all

factors are statistically significant. The percentage wood and the percentage TDF in the fuel blend has virtually no influence on the SR.

Cofiring does not influence the use of excess air, as shown above. Cofiring also does not influence the air heater exit temperature If anything, there was a slight (favorable)

downward trend in air heater exit temperature as a function of sawdust cofiring. That trend is not significant, however; essentially there is no influence. Further, The inclusion of sawdust into the fuel blend had no influence on unburned carbon in the flyash, or loss on ignition (LOI).

The heat and material balances for operations above $177 \mathrm{MW}_{\mathrm{e}}$ gross load were used to evaluate the influences of dry gas loss, moisture in the fuel, and hydrogen in the fuel. These cases indicate that the influence of sawdust and TDF is the increase in moisture in the fuel and hydrogen in the fuel. The latter results from the higher hydrogen/carbon atomic ratios associated with the sawdust and the TDF.

The overall impact of cofiring on net station heat rate is not readily apparent from operating data; the influences are quite minor. Of significance to the heat rate determination is the influence of cofiring on main steam temperatures. In summary, cofiring did not reduce main steam temperatures when operating at any condition. In virtually all cases the main steam temperature was between $240^{\circ} \mathrm{C}$ and $550^{\circ} \mathrm{C}\left(1000^{\circ} \mathrm{F}\right.$ and $1020^{\circ} \mathrm{F}$ ), regardless of fuel blend or load. Hot reheat steam temperatures also were not influenced by cofiring sawdust or sawdust/TDF blends as well.

The only method for analyzing the impact on net station heat rate, then, is to analyze based upon a theoretical turbine heat rate and apply the boiler efficiency to that. Assuming a typical turbine heat rate of $93.8 \mathrm{MJ} / \mathrm{kWh}(8900 \mathrm{Btu} / \mathrm{kWh})$ and a typical boiler efficiency when firing only coal of $\sim 88$ percent, an ideal NSHR of $10.7 \mathrm{MJ} / \mathrm{kWh}$ $(10,100 \mathrm{Btu} / \mathrm{kWh}) \mathrm{can}$ be calculated. At 10 percent sawdust, and an efficiency loss of 0.29 percent (based upon equation [3]), and a constant turbine heat rate, the calculated NSHR would be $10.7 \mathrm{MJ} / \mathrm{kWh}(10,142 \mathrm{Btu} / \mathrm{kWh})$; there would be an increase in NSHR of $33.7 \mathrm{~kJ} / \mathrm{kWh}(32 \mathrm{Btu} / \mathrm{kWh})$. As a practical matter, the measurements made do not provide sufficient information to quantify this with test data. However it is consistent with other tests conducted at other locations

\subsection{Temperature Influences of Cofiring at Willow Island \#2 Boiler}

Both flame temperatures $\left(\mathrm{T}_{\mathrm{f}}\right)$ and furnace exit gas temperatures (FEGT) are of concern when cofiring sawdust and sawdust/TDF blends. Flame temperatures are essential to maintaining the slag in a condition where it will readily flow through slag taps to slag tanks. Furnace exit gas temperatures significantly influence deposition of inorganic matter in the boiler-and particularly influence where that deposition will occur. 


\subsubsection{Flame Temperature Influences of Cofiring at Willow Island \#2 Boiler}

Flame temperatures experienced minimal impact from cofiring activities. $\mathrm{T}_{\mathrm{f}}$ values are not readily measured directly, however they can be calculated using the combustion code developed by NASA. These calculations employ Gibbs Free Energy minimization calculations to account for dissociation of $\mathrm{CO}_{2}$ into $\mathrm{CO}$ and $\mathrm{O}$, and other similar high temperature reactions. Experience with one HVT probe direct measurement of $\mathrm{T}_{\mathrm{f}}$ values at Paradise Fossil Plant showed that estimated actual flame temperatures are about $90 \%$ of the theoretically calculated $\mathrm{T}_{\mathrm{f}}$ values resulting from the CET -89 computer code, on an absolute temperature basis. Experiments measuring the slag temperatures in a cyclone using optical pyrometry at the Allen Fossil Plant confirmed this as a reasonable approximation.

Theoretical and estimated actual flame temperatures have been calculated for 10 full load cases where the sawdust cofiring ranged from 0 to 9 percent (mass basis), and the TDF cofiring ranged from 0 to 6 percent (mass basis). These cases are shown in Table 3 .

Table 3. Estimated Flame Temperatures for Full Load Firing at Willow Island \#2 Boiler

\begin{tabular}{|c|c|c|c|c|c|c|c|c|}
\hline \multicolumn{2}{|c|}{ Case } & \multirow{2}{*}{$\begin{array}{c}\text { Load } \\
(\mathrm{MW})^{*}\end{array}$} & \multicolumn{2}{|c|}{$\%$ Cofiring } & \multicolumn{2}{|c|}{ Theoretical $\mathrm{T}_{\mathrm{f}}$} & \multicolumn{2}{|c|}{ Est. Actual $\mathrm{T}_{\mathrm{f}}$} \\
\hline Date & Time & & Sawdust & TDF & $\mathrm{K}$ & ${ }^{\mathrm{o}} \mathrm{F}$ & $\mathrm{K}$ & ${ }^{\mathrm{o}} \mathrm{F}$ \\
\hline $03 / 11$ & 0304 & 194.71 & 0 & 6 & 2335.1 & 3744.2 & 2100 & 3325 \\
\hline $07 / 02$ & 1826 & 183.52 & 3 & 0 & 2345.4 & 3762.7 & 2110 & 3340 \\
\hline $07 / 23$ & 1738 & 183.00 & 4 & 0 & 2349.5 & 3770.1 & 2115 & 3350 \\
\hline $08 / 02$ & 2000 & 190.14 & 0 & 0 & 2356.2 & 3782.2 & 2120 & 3360 \\
\hline $09 / 20$ & 0935 & 189.44 & 7 & 4 & 2355.5 & 3780.9 & 2120 & 3355 \\
\hline $09 / 22$ & 1730 & 184.05 & 6 & 3 & 2346.0 & 3763.8 & 2110 & 3340 \\
\hline $09 / 23$ & 1620 & 188.07 & 6 & 5 & 2357.9 & 3785.2 & 2122 & 3360 \\
\hline $10 / 10$ & 0954 & 188.81 & 8 & 0 & 2342.9 & 3758.2 & 2110 & 3335 \\
\hline $10 / 30$ & 0906 & 189.52 & 8 & 0 & 2356.6 & 3782.7 & 2120 & 3360 \\
\hline $11 / 04$ & 0911 & 189.48 & 9 & 0 & 2350.7 & 3772.3 & 2115 & 3350 \\
\hline
\end{tabular}

Note that there is very little variation in flame temperature as a function of fuel at full load. Two regression equations have been constructed to estimate flame temperature at Willow Island \#2 boiler, as shown below:

$\left.\mathrm{T}_{\mathrm{f}}=3670+5.9 * \% \mathrm{C}\right)+4.8(\% \mathrm{~W})+6.2(\% \mathrm{TDF})+3.7(\% \mathrm{~L})-617(\mathrm{SR})+0.38\left(\mathrm{~T}_{\mathrm{air}}\right)[6-4]$

And

$\mathrm{T}_{\mathrm{f}}=4248-579(\mathrm{SR})+0.30\left(\mathrm{~T}_{\mathrm{air}}\right)$

Where $\mathrm{T}_{\mathrm{f}}$ is theoretical flame temperature $\left({ }^{\mathrm{o}} \mathrm{F}\right), \% \mathrm{C}$ is percent coal in the fuel blend (mass basis), $\% \mathrm{~W}$ is percent sawdust in the fuel blend (mass basis), \% TDF is percent tire- 
derived fuel in the total fuel blend (mass basis), $\% \mathrm{~L}$ is percent limestone in the total fuel blend (mass basis), $\mathrm{SR}$ is stoichiometric ratio, and $\mathrm{T}_{\mathrm{air}}$ is temperature of the combustion air $\left({ }^{\mathrm{O}} \mathrm{F}\right)$. Theoretical flame temperatures, rather than estimated actual flame temperatures, were used for these calculations because theoretical flame temperatures are the basis for estimating actual flame temperatures. The $r^{2}$ for equation [3] is 0.999 and the $r^{2}$ for equation [4] is 0.937 . Interestingly, the calculation of the significance values for the fuel variables shows that these are not significant contributors to flame temperature. Table 5 presents the probabilities that all variables in equation [3] occurred randomly. Probabilities $<0.05$ are significant; probabilities $<0.01$ are highly significant.

It is interesting that the higher moisture biomass has little impact on flame temperature despite its lower calorific value and its moisture content. The reason is fuel volatility, and the consequent rate of weight loss. Shafizadeh and DeGroot (1977) developed the necessary explanatory equation as shown below:

$$
F_{i}=(d w / d t) h
$$

Where $F_{i}$ is flame intensity, dw/dt is the rate of weight loss of a sample of fuel with respect to time, when being subjected to thermogravimetric analysis (TGA) at a heating rate of $20^{\circ} \mathrm{C} / \mathrm{min}$, and $\mathrm{h}$ is the heat content of the fuel $(\mathrm{cal} / \mathrm{g})$. This equation shows that, while the biomass fuels are lower in calorific value and higher in moisture, the rate of weight loss resulting from their high volatility is sufficient to compensate and to generate high flame temperatures. Consequently, in all cases tested at Willow Island Generating Station \#2 boiler the flame temperatures were sufficient to support good slag formation. In no case did was the flame temperature compromised by the practice of cofiring.

\subsubsection{Furnace Exit Gas Temperature Influences of Cofiring at Willow Island \#2 Boiler}

The practice of cofiring at Willow Island caused a decrease in FEGT as is shown in Figure 6-14. Note the trend shown in this figure based upon sawdust addition. 


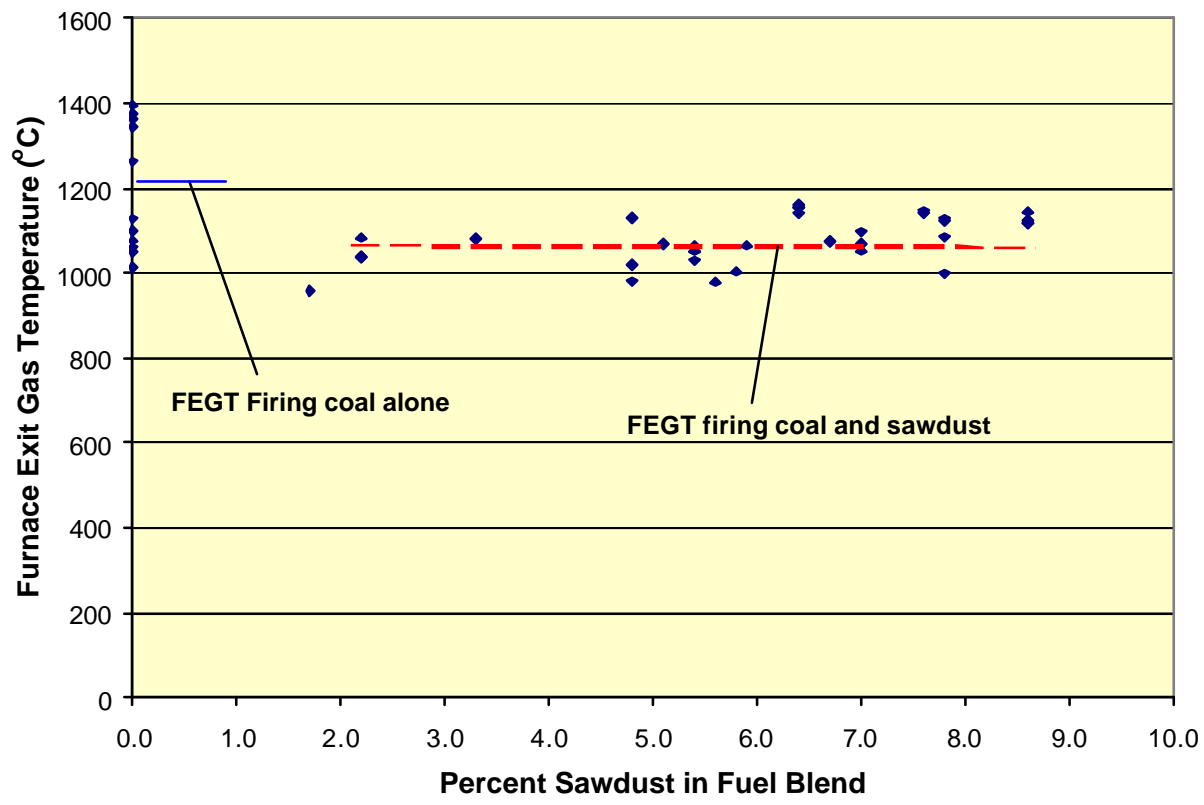

Figure 6-14. The influence of cofiring sawdust on furnace exit gas temperature

Note that the trend is quite flat and possibly increasing slightly as the percent sawdust exceeds 5 percent. It is useful to observe that, while this trend occurred, the main steam and reheat steam temperatures did not decrease also. That was caused by a modest increase in flue gas volume when sawdust was added to the fuel blend. Figure 615 presents the data of Figure 6-14 in English units.

Operationally, then, the cofiring project has demonstrated benefits without incurring any capacity penalties; and with the experience of only minor efficiency penalties. The influences on flame temperature are negligible, and the FEGT results are generally positive. 


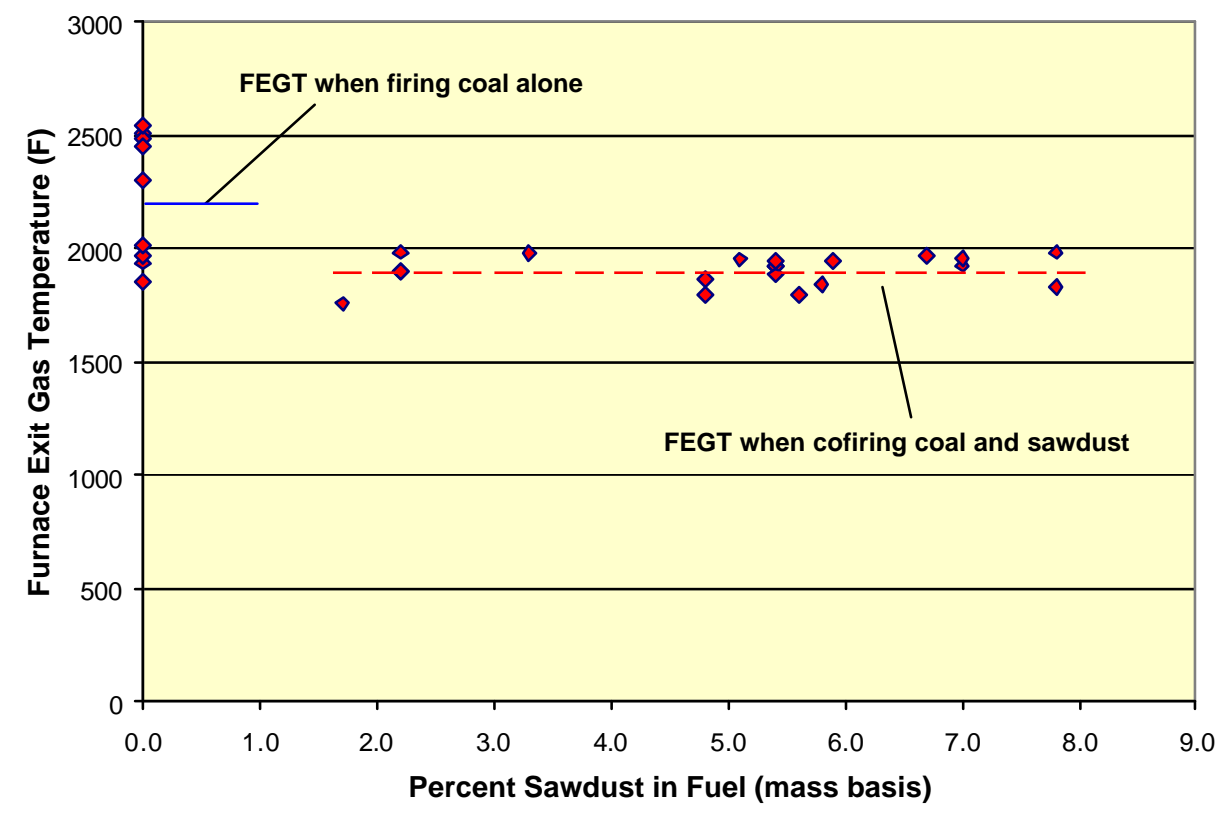

Figure 6-15. The influence of cofiring on FEGT (English units)

The influence of sawdust on FEGT merits additional investigation. Cyclone boilers installing and operating overfire air systems also experienced reduced FEGT values, however many of them also experienced a decrease in main steam and reheat steam temperatures. That experience occurred at Willow Island Generating Station when implementing overfire air in 2002-2003. The decrease in FEGT associated with sawdust cofiring, however, did not decrease main steam or reheat steam temperatures. Figures 616 and 6-17 depict the influence of cofiring sawdust on main steam temperatures to illustrate this issue.

The absence of a decrease in main steam or reheat steam temperature when cofiring sawdust—despite the decrease in FEGT — can readily be explained. When cofiring sawdust with a heat content of $\sim 11.6 \mathrm{MJ} / \mathrm{kg}(\sim 5000 \mathrm{Btu} / \mathrm{lb})$ and a moisture content of $\sim 40$ percent, the mass flow of gaseous combustion products increases. This increase in gas flow across the heat transfer surfaces compensates for the decrease in temperature.

The ability of the cofiring system to reduce FEGT carries with it operational benefits. If deposition of iron or calcium based inorganic matter either as slagging or fouling deposits is to occur, it is more likely to occur as slag in the main furnace where control of such material is more easily accomplished. Reducing FEGT reduces the potential for fouling. 


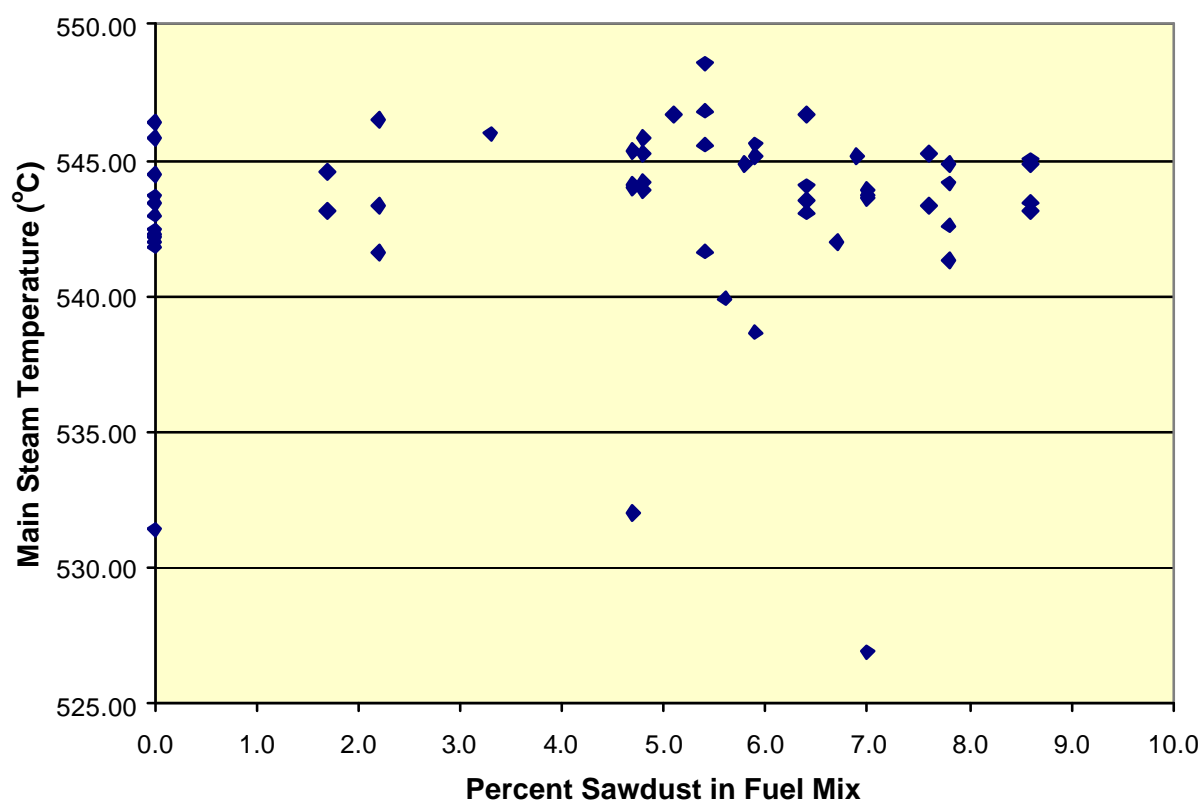

Figure 6-16. The influence of cofiring on main steam temperatures $\left({ }^{\circ} \mathrm{C}\right)$

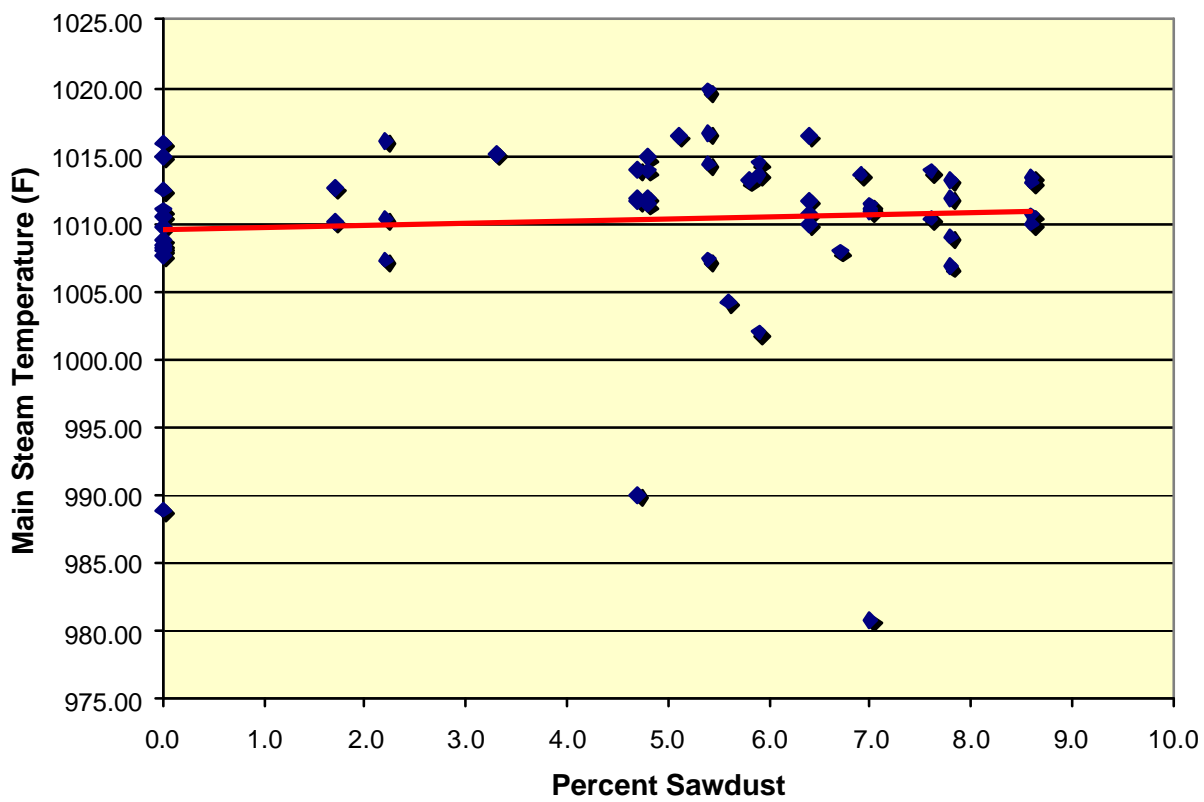

Figure 6-17. The influence of cofiring on main steam temperatures $\left({ }^{\circ} \mathrm{F}\right)$ 
The operational consequence of the reduced FEGT must also be considered in the context of the influence of cofiring on $\mathrm{T}_{250}$ temperatures. Note that the base/acid (B/A) ratio of the sawdust is incredibly high-2.62 - particularly when compared to the coals burned with $\mathrm{B} / \mathrm{A}$ ratios on the order of $0.3-0.4$. Even with very low ash percentages, the sawdust can have a modest influence on the $\mathrm{B} / \mathrm{A}$ ratio of the fuel, thereby decreasing the $\mathrm{B} / \mathrm{A}$ ratio of the blend as a whole. Similarly the iron in the fine wires within TDF can increase the B/A ratio. Both opportunity fuels, individually and collectively, can help flux the slag in the cyclone barrel.

The operational consequences of the fuel blend also relate to the volatility of the fuel itself. Through the use of sawdust, the plant could procure slightly lower volatile coal and maintain the volatility requirements for ignition and combustion in the cyclone

barrel. This may have economic advantages for one or more cyc lone boiler operators.

\subsection{Environmental Consequences of cofiring at Willow Island \#2 Boiler}

Cofiring biomass - sawdust - and TDF has the potential to accomplish environmental benefits for Willow Island Generating Station. Specific considerations include:

- $\mathrm{SO}_{2}$ reduction

- $\mathrm{NO}_{\mathrm{x}}$ reduction

- Mercury reduction

- Greenhouse gas reduction

Some of these benefits were obtained; others remained elusive during the sawdust cofiring at Willow Island Generating Station (see Tillman, Payette, and Banfield, 2003).

\subsection{1. $\mathrm{SO}_{2}$ Reduction from Cofiring at Willow Island \#2 Boiler}

Biomass cofiring is expected to reduce $\mathrm{SO}_{2}$ emissions; sawdust is virtually sulfur free. Figure 6-16 summarizes the $\mathrm{SO}_{2}$ emissions as a function of biomass cofiring. Note that there is a trend towards $\mathrm{SO}_{2}$ reduction, however there is significant scatter in the results as a consequence of natural variability in the coal being burned. 


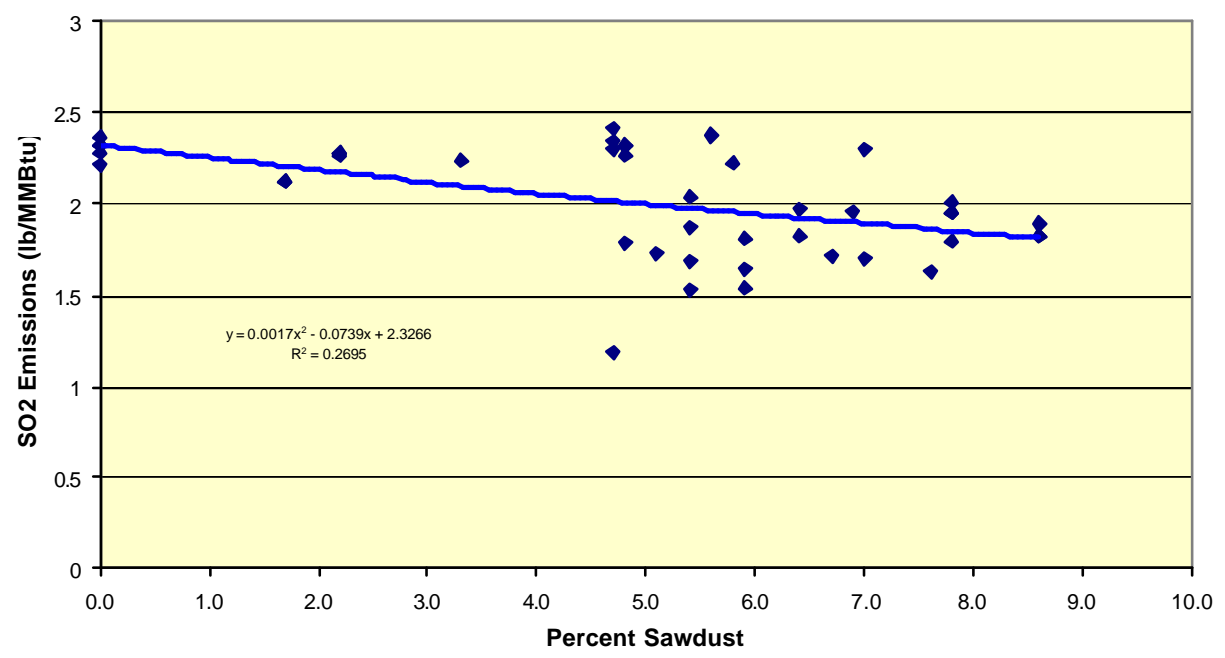

Figure 616. $\mathrm{SO}_{2}$ Emissions as a Function of Sawdust Cofiring at Willow Island \#2 Boiler

A multiple linear regression equation can be created, however it lacks any hint of robustness. What is clear from these data is the fact that coal composition has a natural variability. Further, as sources vary from day to day as a function of reclaim, a precise assessment of $\mathrm{SO}_{2}$ reduction can not be statistically quantified. It is sufficient to note that the biomass is sulfur-free, and the TDF is relatively low in sulfur; and these will contribute to a reduction in this pollutant.

\subsection{2. $\mathrm{NO}_{\mathrm{x}}$ Emissions Resulting from Cofiring at Willow Island \#2 Boiler}

Cofiring sawdust, and combinations of sawdust and TDF, did not achieve the expected reductions in $\mathrm{NO}_{\mathrm{x}}$ emissions. It had no influence increasing or decreasing $\mathrm{NO}_{\mathrm{x}}$ emissions. The sawdust and TDF both reduced the fuel nitrogen entering the cyclone barrel. The sawdust and TDF did not increase, or decrease, flame temperatures significantly but they did decrease FEGT. $\mathrm{NO}_{\mathrm{x}}$ data showed significant variability, and regression analysis yielded no equations that were robust. The variability in the $\mathrm{NO}_{\mathrm{x}}$ emissions could well be a function of the inherent variability of the coal. The conclusion was that can be said is that cofiring did not reduce $\mathrm{NO}_{\mathrm{x}}$ emissions.

It is useful to attempt to understand why $\mathrm{NO}_{\mathrm{x}}$ emissions did not respond to cofiring at Willow Island Generating Station, given the success in using cofiring for $\mathrm{NO}_{\mathrm{x}}$ trim at Albright Generating Station, and at such cyclone boilers as Bailly Generating Station Unit \#7, Michigan City Generating Station Unit \#12, and the Allen Fossil Plant .

Previous research has demonstrated that the $\mathrm{NO}_{\mathrm{x}}$ reduction mechanism associated with sawdust cofiring involves creating a highly volatile fuel-rich region to enhance staged combustion. For cyclone boilers, this mechanism has worked because such boilers 
typically are fired with significantly more excess air - and consequently higher stoichiometric ratios - than is practiced at Willow Island Generating Station. Operation of the cyclone boiler at Willow Island causes the cyclone to be operated in a highly fuel staged condition. This is further augmented by the split damper installation at Willow Island. Internal staging within the cyclone barrel is maximized, as is the purpose of the split damper design common to many cyclone installations.

\subsubsection{Mercury Emissions Impacts of Biomass Cofiring at Willow Island}

Careful testing of the sawdust being fired at Willow Island Generating Station shows that the sawdust contains $0.0013 \mathrm{mg} / \mathrm{kg}$ mercury (range is $0.0010-0.0020 \mathrm{mg} / \mathrm{kg}$ of mercury). This compares to $0.18 \mathrm{mg} / \mathrm{kg}$ of mercury in the coal, as reported in the Toxic Release Inventory data (Tillman, Payette, and Banfield, 2003). Cofiring reduces mercury emissions by reducing the feed of mercury to the boiler.

\subsubsection{Greenhouse Gas Emissions Impacts of Biomass Cofiring at Willow Island}

It has been shown that cofiring reduces fossil $\mathrm{CO}_{2}$ emissions directly by $1.0-1.1$ metric tons $\mathrm{CO}_{2}$ /ton biomass burned. Further, it has been shown that cofiring reduces fossil $\mathrm{CO}_{2}$ equivalent emissions by an additional 2 tons for every ton of sawdust burned in a power plant-avoiding methane formation in landfills and other land applications.

The cofiring of sawdust at Willow Island has reduced greenhouse gas emissions by $>6,500$ metric tons $\mathrm{CO}_{2}$ directly, and by a total of over 20,000 metric tons fossil $\mathrm{CO}_{2}$ equivalent in the year 2002. Since Allegheny Energy has committed to a voluntary reduction of greenhouse gases, this project has made a contribution to the overall corporate target.

\subsection{Conclusions}

The cofiring at Willow Island Generating Station has involved over 4000 hours of firing sawdust and sawdust/TDF mixtures. As such, it has demonstrated that there are no negative impacts on boiler capacity, only minor impacts on boiler efficiency, potentially positive impacts on combustion and furnace temperatures, and favorable impacts on fuel costs.

There are favorable fuel characteristics that improve combustion. The use of sawdust does not decrease combustion temperatures, but does decrease FEGT with benefits for management of slagging and fouling. The blending of sawdust with coal causes a modest increase in $\mathrm{B} / \mathrm{A}$ ratio and a concomitant decrease in $\mathrm{T}_{250}$ temperature. The use of high volatile sawdust opens up some coal procurement flexibility with particular attention to the volatile matter in the coal procured.

The cofiring at Willow Island Generating Station has demonstrated that the use of sawdust and TDF can reduce $\mathrm{SO}_{2}$ emissions, however it has not had the beneficial impact 
on $\mathrm{NO}_{\mathrm{x}}$ emissions that were anticipated. Cofiring, however, has had favorable impacts on mercury emissions and greenhouse gas emissions. 


\subsection{The Albright Generating Station Cofiring Design and Construction}

The demonstration of cofiring at the Albright Generating Station was fundamentally different from that which occurred at the Willow Island Generating Station. Albright Generating Station Unit \#3 is a $140 \mathrm{MWe}$ (net) tangentially-fired (T-fired) boiler equipped with a low $-\mathrm{NO}_{\mathrm{x}}$ firing system including 3 levels of separated overfire air (SOFA). Like the Willow Island Generating Station, the Albright Generating Station fires washed Pittsburgh Seam bituminous coal, however the comparisons stop there.

The Albright Generating Station demonstration was originally constructed at Seward Generating Station of GPU Genco (now Reliant Energy) in Seward, PA. That installation, shown in Figures 7-1 through 7-3, employed separate injection of sawdust in a 32 MWe wall-fired boiler. The Seward demonstration proved that cofiring in a wallfired boiler could significantly reduce NOx emissions, according to the following relationship:

$\mathrm{NO}_{\mathrm{x}}=18.92-647.4\left(\mathrm{~W}_{\mathrm{m}}\right)+9.66(\mathrm{~L})+59.9\left(\mathrm{EO}_{2}\right)$

Where $\mathrm{NO}_{\mathrm{x}}$ is measured as ppmvd at $3 \% \mathrm{O}_{2}$ (dry basis), $\mathrm{Wm}$ is the percentage sawdust cofired in the boiler on a mass basis, $\mathrm{L}$ is load measured as main steam flow in $\mathrm{kg} / \mathrm{s}$, and $\mathrm{EO}_{2}$ is excess $\mathrm{O}_{2}$ reported in the control room on a total basis (Battista, Hughes, and Tillman, 2000).

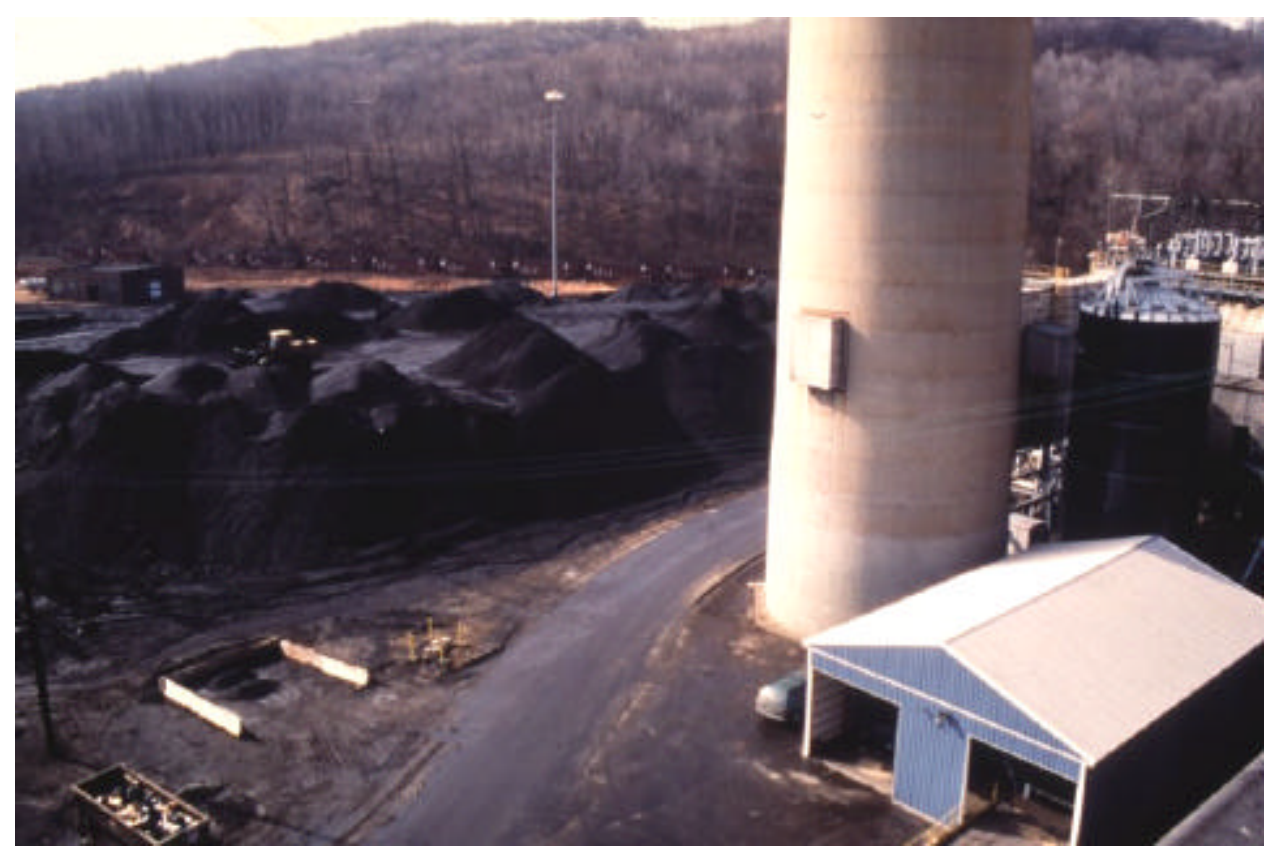

Figure 7-1. The Seward Generating Station demonstration under construction 


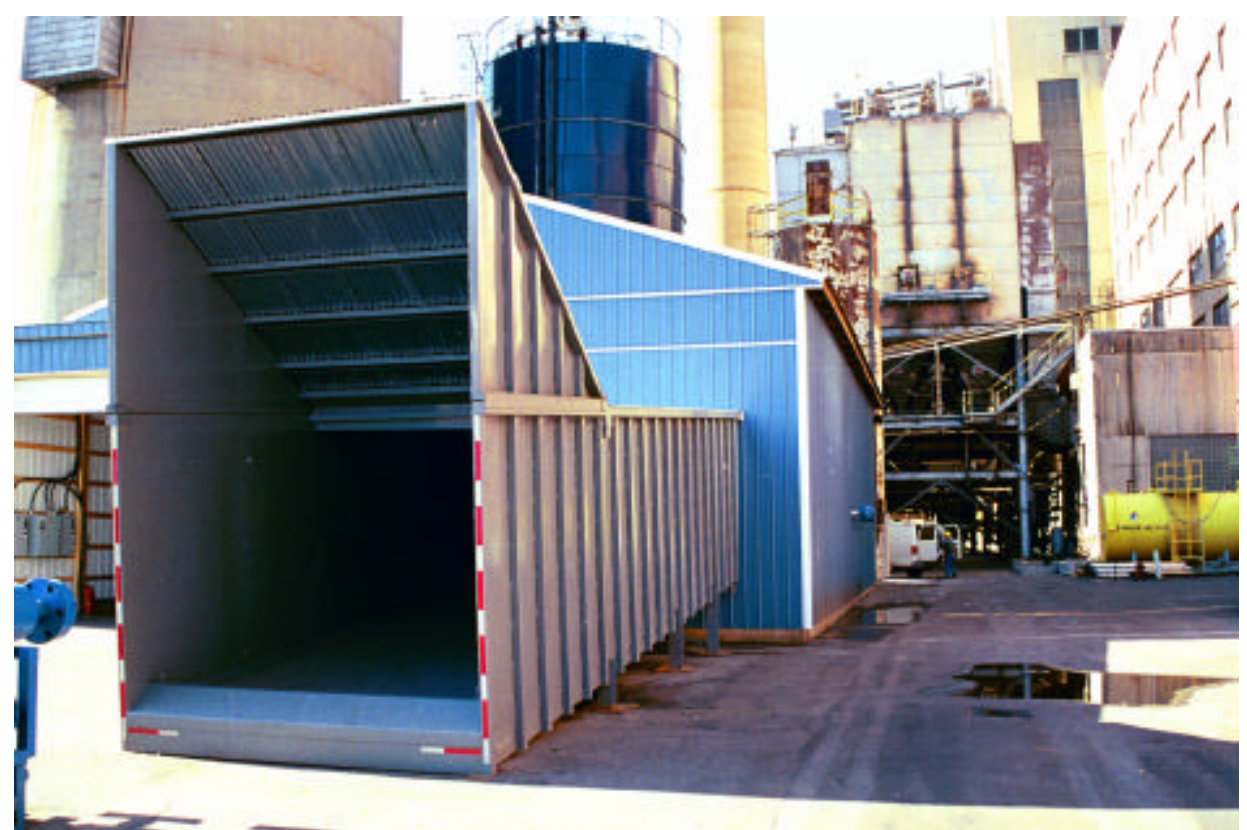

Figure 7-2. Ground view of the Seward Demonstration under construction, featuring the walking floor unloading system. Note the silo for sawdust storage in the background

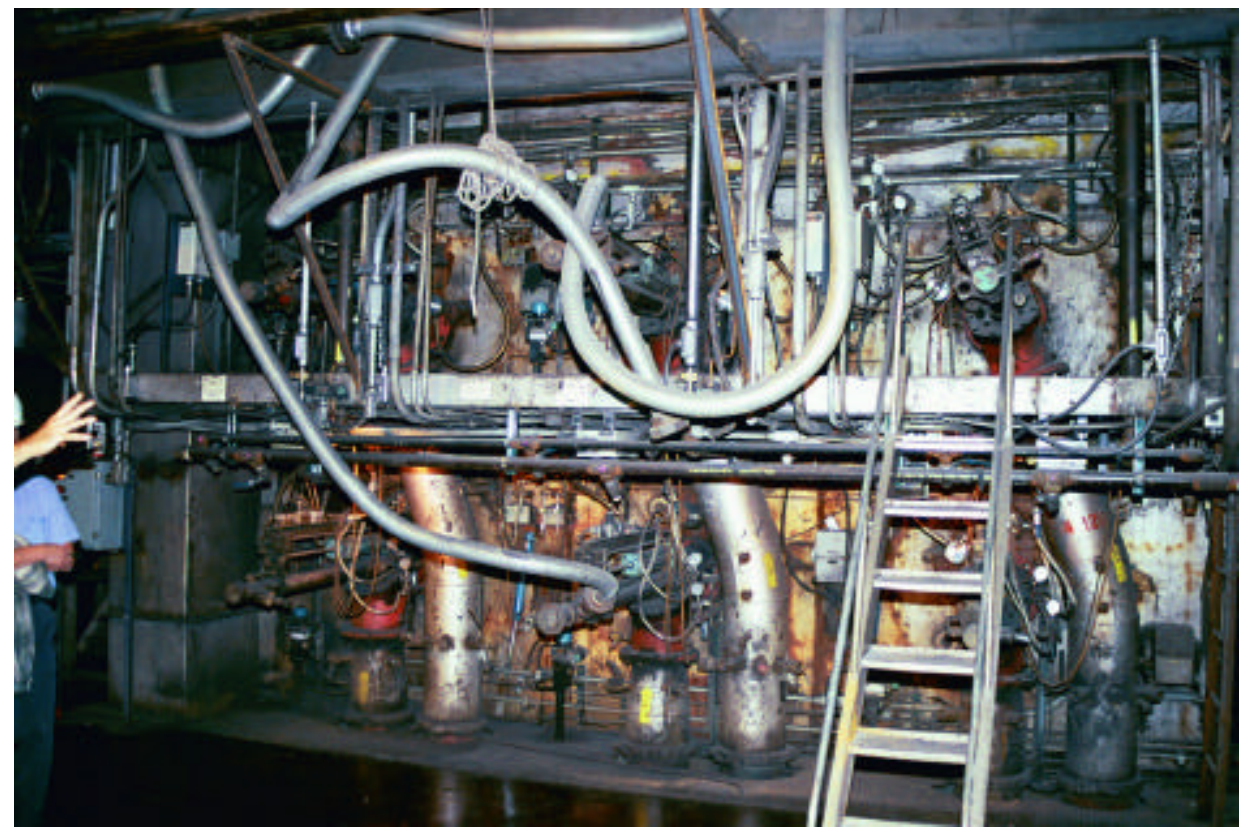

Figure 7-3. The Burner Front at Seward Generating Station with flexible piping connecting 2 burners to the sawdust delivery system 
The Seward Demonstration featured a walking floor unloader, as shown in Figure 7-2, in order to prevent penetrating the ground during construction. It employed a trommel screen and complete pneumatic handling of sawdust. It employed an agricultural silo with an auger unloading system, capable of handling up to 270 tons of green sawdust. From the silo, biomass was metered and blown into the boiler through the centerpipe of the two center burners in each row of 3 burners.

In the design of the Albright Generating Station demonstration, numerous changes were made in the process in order to improve upon the design. At the same time, recognizing the success that Seward enjoyed using biomass for $\mathrm{NO}_{\mathrm{x}}$ trim, the Albright Generating Station demonstration sought to capitalize upon the $\mathrm{NO}_{\mathrm{x}}$ control mechanisms.

\subsection{Albright Generating Station Cofiring System Design}

The process design for the Albright Generating System cofiring demonstration somewhat paralleled the design for Willow Island in concept; however numerous differences occurred in equipment selection. The differences were caused largely by the following factors:

- Moving an existing demonstration, where equipment had already been selected based upon different project criteria;

- Favoring pneumatic conveyance of sawdust, rather than mechanical conveyance of sawdust

- Injecting the sawdust directly into the boiler, requiring changes in the final handling and control approaches

The Albright design, described by Payette, Banfield, Nutter, and Tillman (2002) involved accepting the sawdust through the walking floor receiver previously shown in Figure 7-2. This receiver is slightly wider than a walking floor van, and can hold the entire load of a single truck. This provides for surge capacity in the unloading process. The discharge of the walking floor unloader is a series of screw conveyors transporting the sawdust to a 30 ton/hr disc screen. The capacity of the disc screen matches the rest of the equipment, and is therefore somewhat lower than the capacity of the disc screen at Willow Island Generating Station.

A disc screen was installed at Albright despite the availability of a trommel screen, and despite the high quality product generated by the trommel screen. Dust management was the critical issue, and a disc screen with covers generates less dust in the work area than the trommel screen. Disc screens have been successfully deployed in the forest products industry, and in the waste-to-energy industry; that experience transferred directly to the Albright and Willow Island stations. 
The processing equipment was housed in a metal building in order to manage the entire process. The building also housed the motor control center and all other electrical systems.

The $<6.35 \mathrm{~mm}(<1 / 4$ ") sawdust from the screen was deposited in a bin and then pneumatically transported to the top of the agricultural silo. Material rejected as being oversized was originally ground in a research grinder; when that proved unsuccessful in a commercial application, it was returned to the vendor and the oversized material-less than 5 percent of the incoming feedstock-was disposed of. Some employees used a portion of this as mulch on their own property. Some was landfilled. Eventually a 2stage grinder and associated dust management system was purchased to achieve particle size reduction of the oversized product.

From the silo, sawdust was reclaimed on demand, fed through a surge hopper and onto a weigh belt conveyor feeding a live bottom bin. The live bottom bin discharged sawdust into two rotary airlocks, each supported by blowers. This arrangement transported the sawdust to opposite corners of the T-fired boiler.

The injection into the boiler was accomplished with two specially designed injectors capable of following the burner tilts. The boiler has four rows of burners; the injectors were installed between the $\mathrm{B}$ and $\mathrm{C}$ rows of burners. The burners and sawdust delivery system were designed with a tip velocity of $25.5 \mathrm{~m} / \mathrm{s}(5000 \mathrm{ft} / \mathrm{min})$ and with an air/fuel mass ratio of $2 \mathrm{~kg}$ air/ $\mathrm{kg}$ fuel. This achieved a sub-stoichiometric air/fuel ratio, and a fuel speed sufficient to overcome the flame speed of biomass. The first consideration was essential for $\mathrm{NO}_{\mathrm{x}}$ control; the second consideration was a safety issue.

It should be noted that each injection point in the boiler was fed by a separate part of the live bottom bin, and each injection point was fed through its own rotary airlock and blower. This ensured that the supply of biomass would be equal on each side of the boiler. Further, it ensured that the flow of air to each side of the boiler would be equal, and that the location of the fireball in the furnace would not be affected by cofiring.

The system used two independent control systems. One set of controls manages the flow of fuel to the silo; a second set of controls manages the flow of sawdust to the boiler. The second set of controls allows the system operator to set the flow of sawdust - up to 5.5 tonnes/hr (6 tons/hr) to the boiler-at his discression. It also permits the operator to shut down the flow of sawdust with an emergency stop if, for any reason, the operator believes that such action is in the best interest of the boiler and the power plant.

\subsection{Construction of the Albright Generating Station Demonstration}

The Albright Generating Station demonstration system was relocated from the Seward Generating Station and constructed at this West Virginia power plant during the spring of 2001. The pictures presented below depict the construction activities. 
It should be noted that, like Willow Island, the Albright demonstration encountered poor soils conditions. Construction required pouring an extensive sub-foundation made from flowable fill. The flowable fill was produced from flyash supplied by the plant as a consequence of coal combustion.

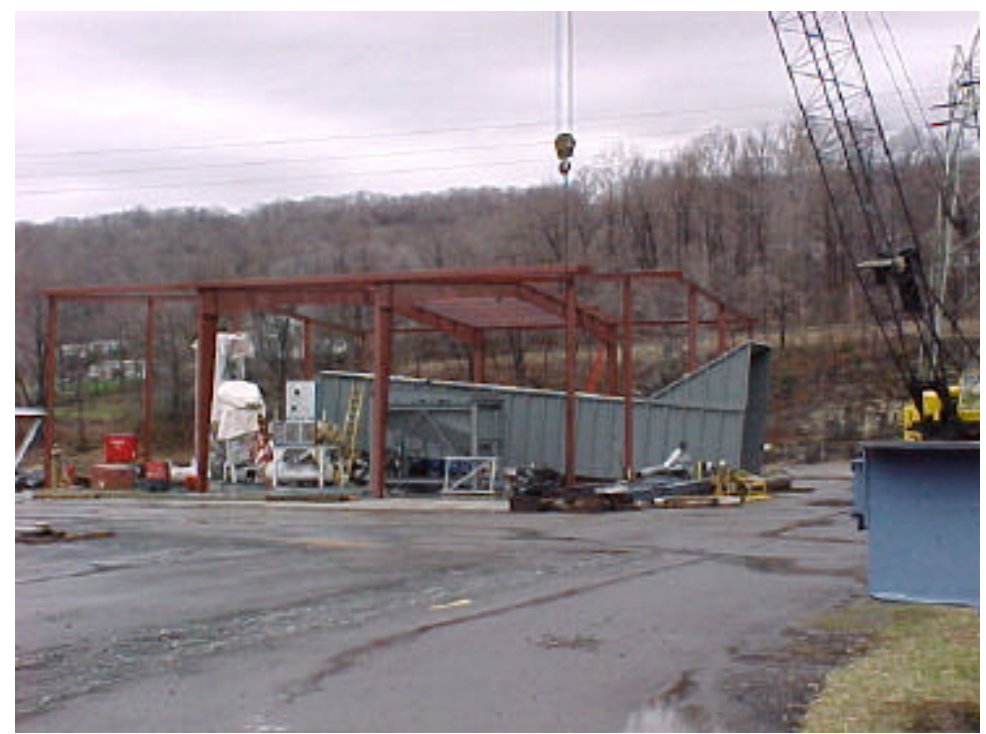

Figure 7-4. Framing the Building for the Albright Demonstration. Note the walking floor unloader already in place.

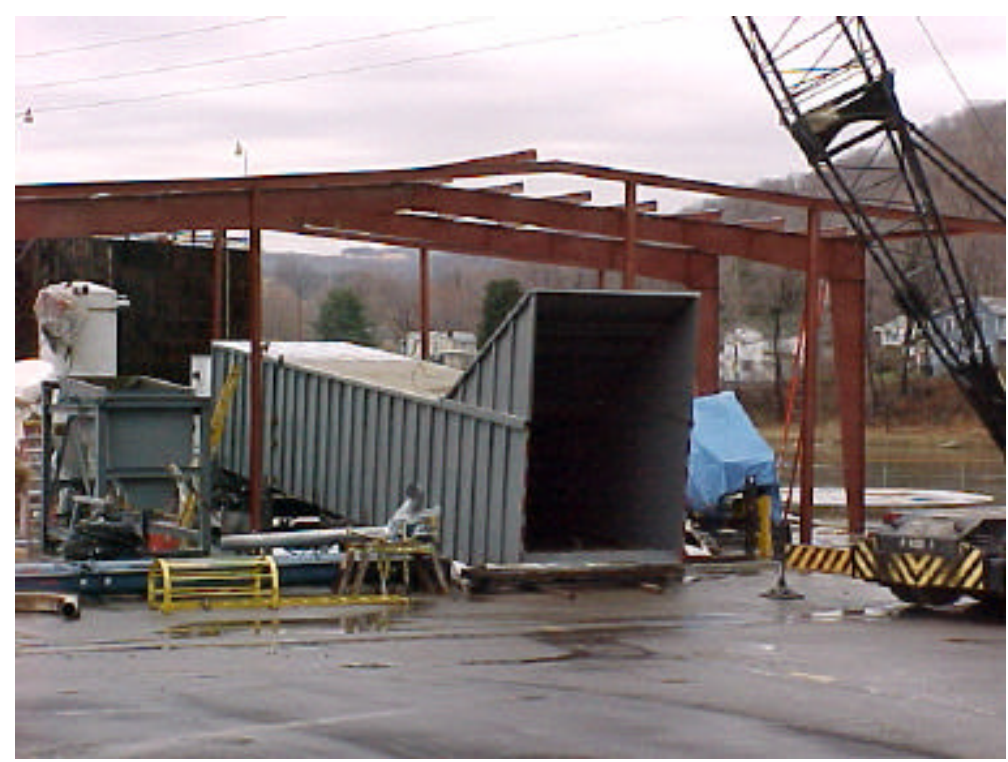

Figure 7-5. Framing the Albright building-front view featuring walking floor unloader 


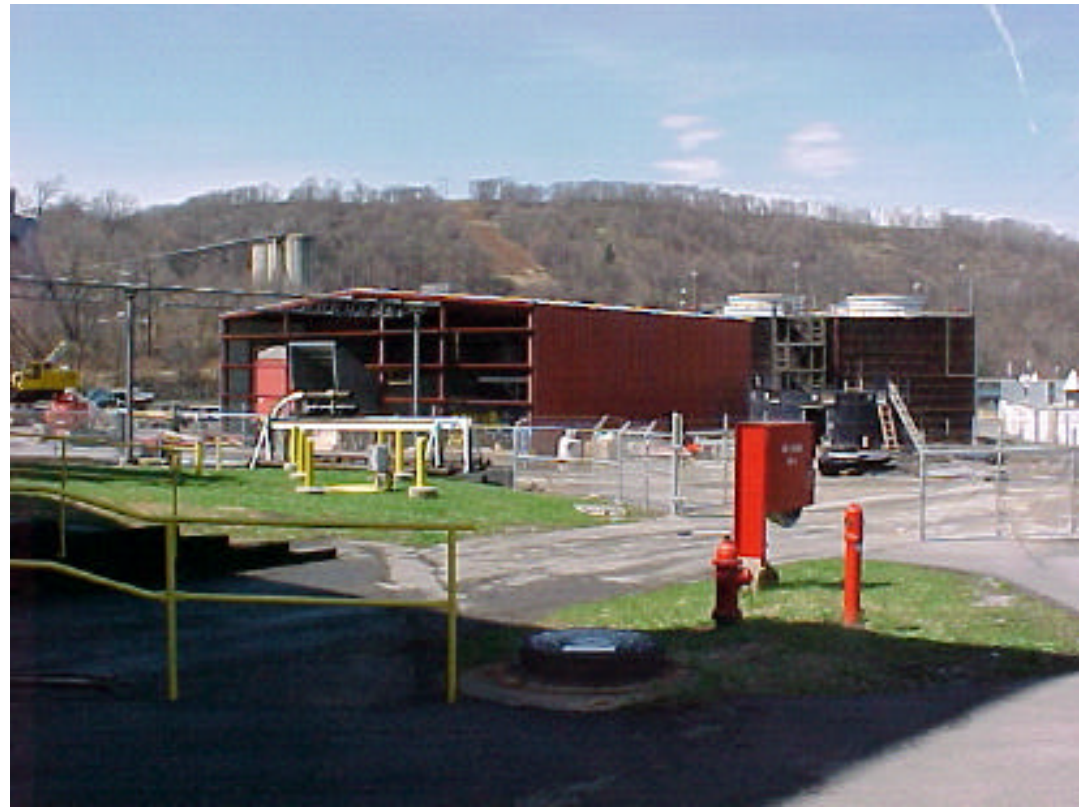

Figure 7-6. The Albright building partially enclosed, with the silo construction started (to the right of the building)

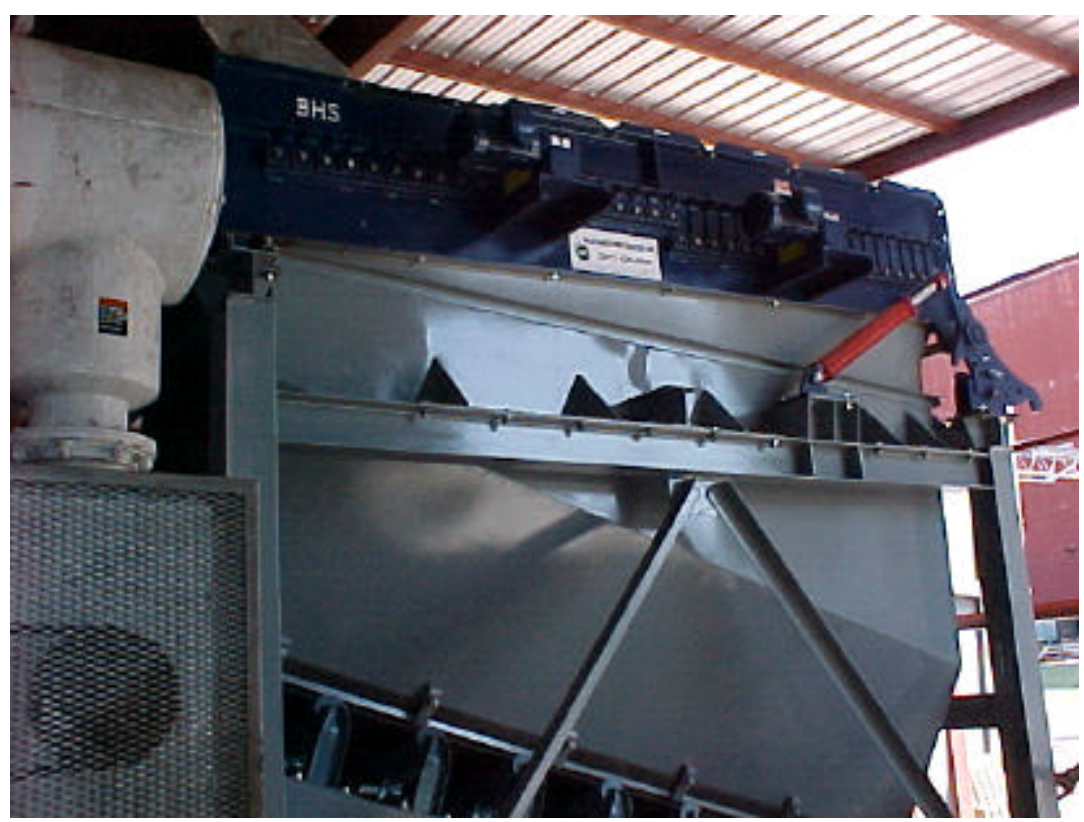

Figure 7-7. The 30 disc screen installed at the Albright demonstration. Note that the building has not been completely enclosed at this point 


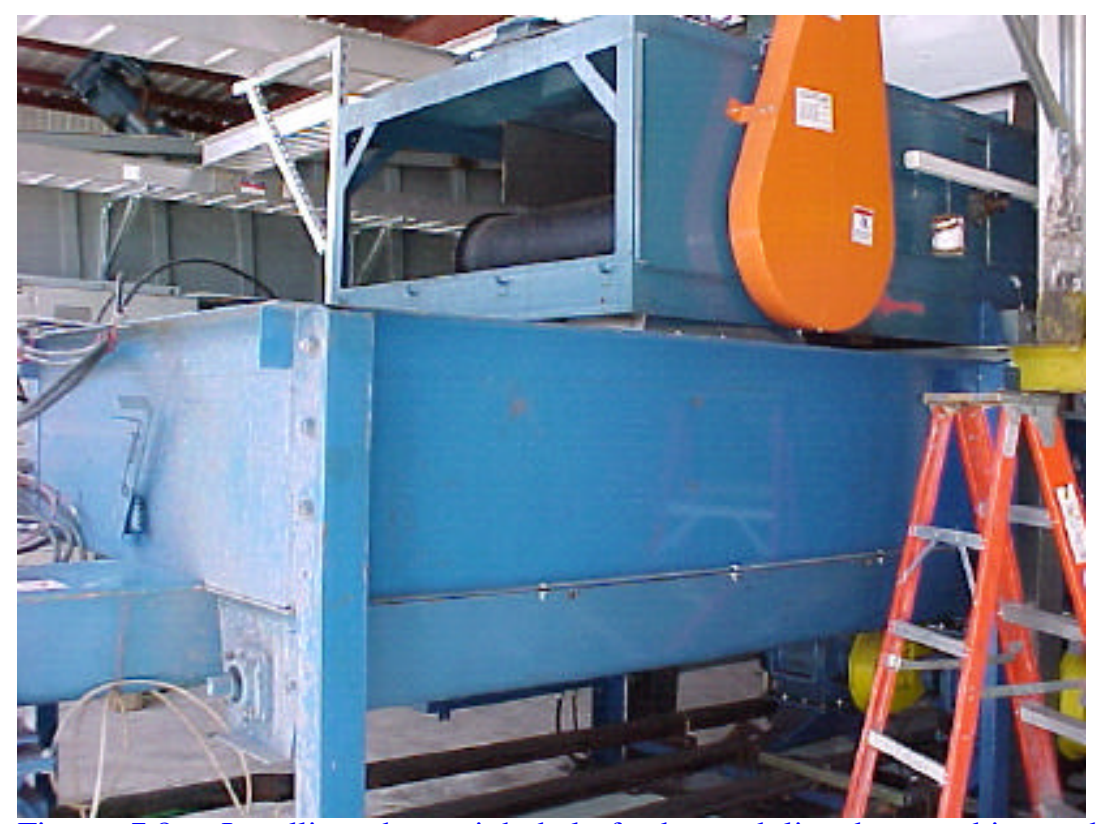

Figure 7-8. Installing the weigh belt feeder and live bottom bin at the Albright demonstration

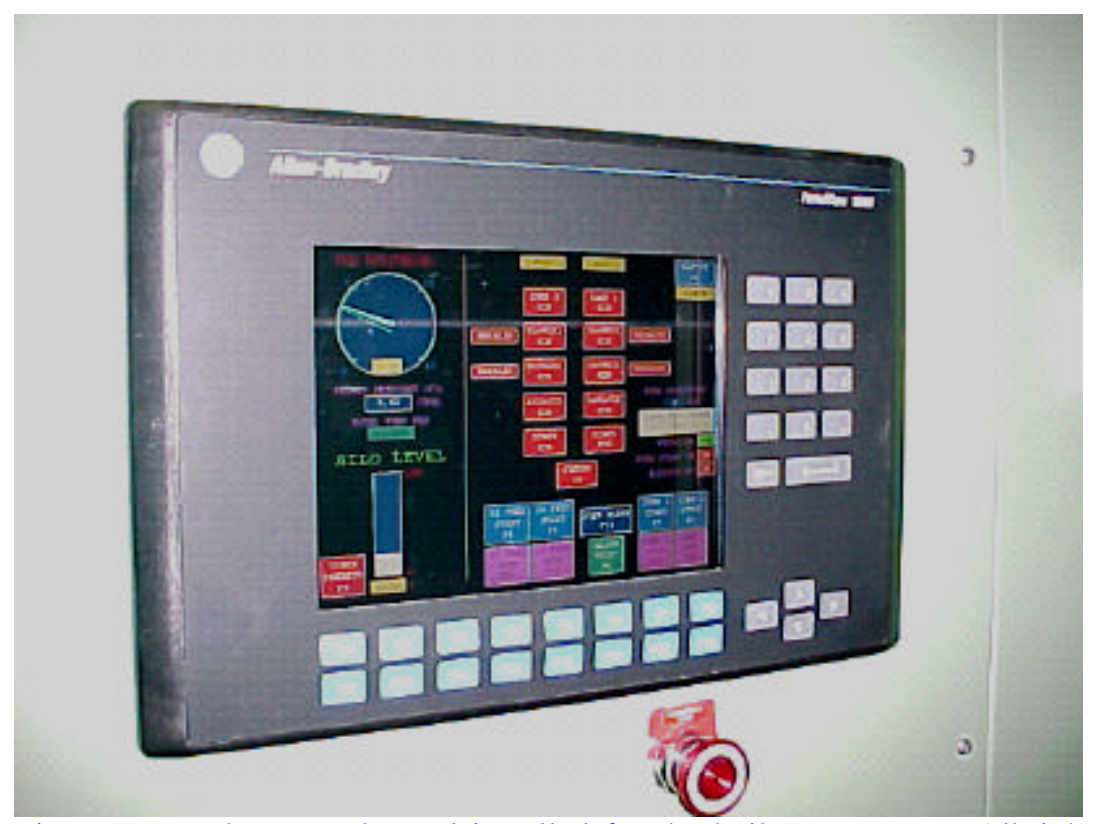

Figure 7-9. The control panel installed for the boiler operator at Albright Generating Station. Note the emergency stop just below the panel. 


\subsection{Capital Cost of the Albright System}

The capital cost of the Albright System, as experienced in the demonstration, is of little meaning since it was complicated by moving existing equipment from another demonstration to the Albright Generating System site. Much of the equipment had been purchased previously. At the same time new equipment such as the disc screen, the burner inserts, and the secondary grinder were purchased for this site. Further, improvements were made to the existing equipment.

Given the situation, we have developed a capital cost estimate for the project assuming that it would be constructed with new equipment and without relocation costs. That capital cost estimate is presented in Table 7-1.

Table 7-1. Estimated Capital Cost of the Albright Cofiring Demonstration if Constructed as New

\begin{tabular}{|c|c|c|}
\hline Number & Description & Capital Cost \\
\hline \multirow[t]{13}{*}{1} & $\begin{array}{l}\text { Process Equipment } \\
\text { Burners }\end{array}$ & $\$ 882,700$ \\
\hline & Disc Screen & \\
\hline & Overs 2-stage grinder & \\
\hline & $\begin{array}{l}\text { Dust control for grinder } \\
\text { Screw conveyor }\end{array}$ & \\
\hline & $\begin{array}{l}\text { Sawdust receiving bin, blower, } \\
\text { And cyclonet }\end{array}$ & \\
\hline & Storage silo and unloader & \\
\hline & Paddle conveyor & \\
\hline & $\begin{array}{l}\text { Surge hopper and live bottom } \\
\text { bin }\end{array}$ & \\
\hline & Weigh belt feeder & \\
\hline & Rotary airlocks and blowers & \\
\hline & Walking floor unloader & \\
\hline & $\begin{array}{l}\text { Motor starters, Motor Control } \\
\text { Centers, and Related }\end{array}$ & \\
\hline & System controls & \\
\hline 2 & Engineering Studies & $\$ 82,100$ \\
\hline & & \\
\hline 3 & Construction & $\$ 710,000$ \\
\hline 4 & Home Office Support and Other & $\$ 135,600$ \\
\hline & TOTAL & $\$ 1,810,400$ \\
\hline
\end{tabular}

The system, with a capacity for supplying 5.5 tonnes/hr (6 tons/hr) of sawdust to the Albright Unit \#3 boiler, effectively could support about $6 \mathrm{MW}_{\mathrm{e}}$, or 4.3 percent of the 
electricity generated at the station. The capacity limitation resulted from the previous demonstration.

On the basis of the estimate above, the Albright Generating Station system, if built as a new installation, would cost $\$ 300 / \mathrm{kW}$ supported by biomass. Like the Willow Island demonstration, it is reasonably automated and requires personnel only for truck unloading. This labor requirement may well be reduced over time and experience.

Note that the costs for both Albright and Willow Island are quite similar. Differences occur in the scale of certain pieces of equipment (e.g., the capacities of the disc screens, the capacities of the storage systems). Consequently the Willow Island demonstration had a capit al cost associated with it of $\$ 2.3$ million compared to the $\$ 1.8$ million associated with a new Albright system. The capital cost of the Willow Island system could be considered either $\$ 180 / \mathrm{kW}$ or $\$ 270 / \mathrm{kW}$, depending upon whether the theoretical capacity is used as the basis or whether the experience capacity is used as the basis. The $\$ 270 / \mathrm{kW}$ associated with the Willow Island system is not appreciably different from the $\$ 300 / \mathrm{kW}$ attributable to the Albright system. There are several reasons for this comparability:

- Comparable processing functions (receiving, screening, grinding of oversized particles, storage, metering)

- The fact that the components for separate injection, while more complex, can be smaller. The Willow Island demonstration had to be capable of discharging $45-68$ tonnes $/ \mathrm{hr}(50-75$ tons/ $\mathrm{hr}$ ) to the main coal belt while the surge hopper, weigh belt feeder, rotary airlocks and blowers only had to supply the boiler with 5.5 tonnes/hr (6 tons/hr).

There are several factors that could be used to alt er this cost estimate including the following:

- Changing the degree of automation

- Increasing the capacity of critical components to increase the generating support of the unit as a whole

These could be used to increase or decrease the capital cost of the system expressed in $\$ / \mathrm{kW}$ supported by biomass. 


\subsection{Operational Testing Results at the Albright Generating Station Demonstration}

Cofiring testing was conducted at the Albright Generating Station during the following time periods:

- May 30-31, 2001 (Baseline testing)

- June $19-21,2001$

- June 25 - 27, 2001

- July $24-27,2001$

Cofiring levels ranged from $3.5 \mathrm{ton} / \mathrm{hr}$ sawdust to 6.0 ton/hr of sawdust. Loads were predominantly $130 \mathrm{MW}_{\mathrm{e}}$ (net) although some $115-120 \mathrm{MW}_{\mathrm{e}}$ (net) loads were also tested. Baseline testing involved part load testing at $90 \mathrm{MW}_{\mathrm{e}}$ and $110 \mathrm{MWe}$ as well.

A 100-hr test also was performed in October 2001 to determine the commercial viability of the Albright cofiring concept; further this test was designed to confirm the results obtained during the May - July 2001 testing.

Pictures of the system in operation are shown in Figures 8-1 through 8-5. These depict the basic operations of the unit.

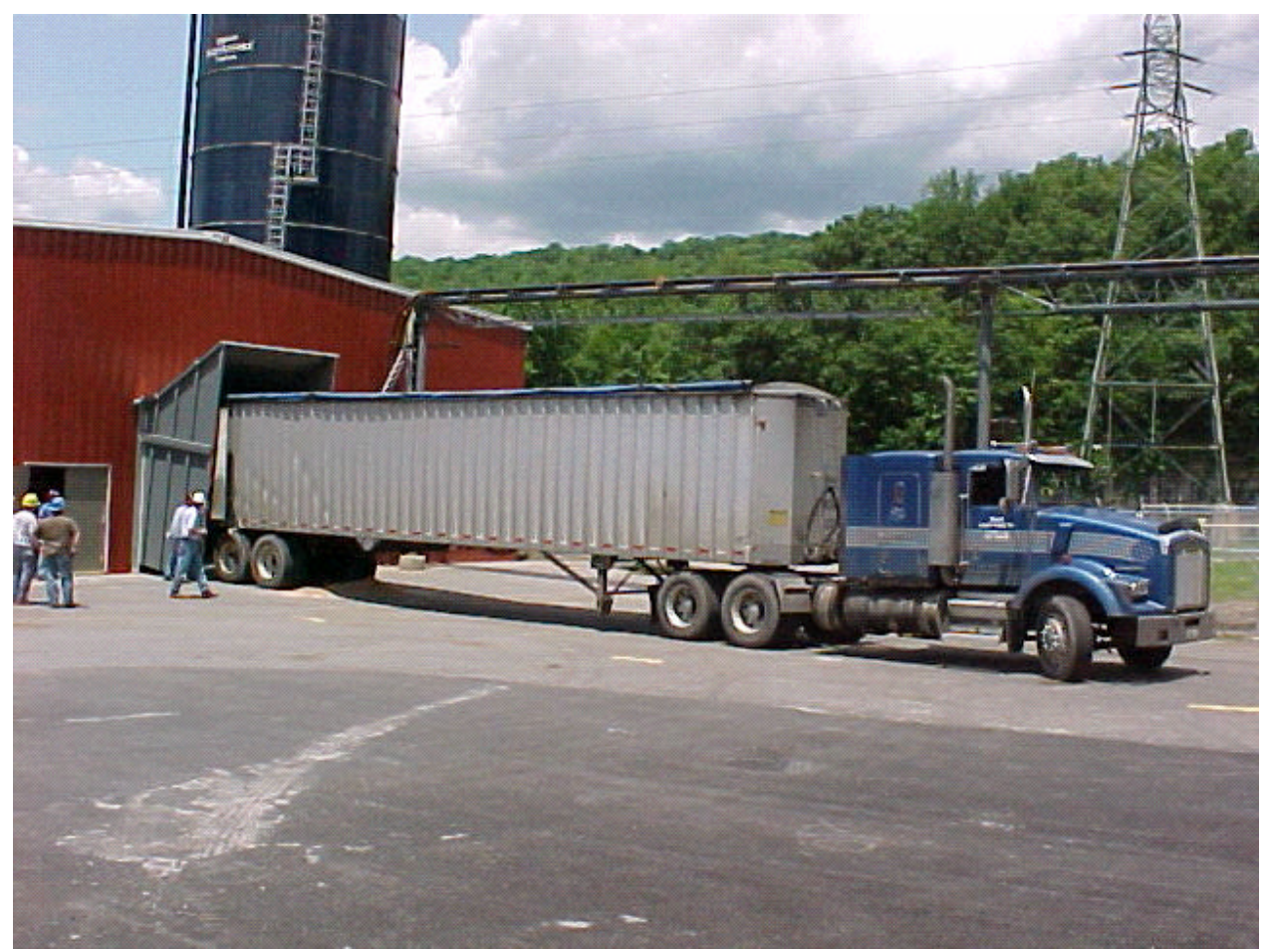


Figure 8-1. Sawdust being received at Albright Generating Station

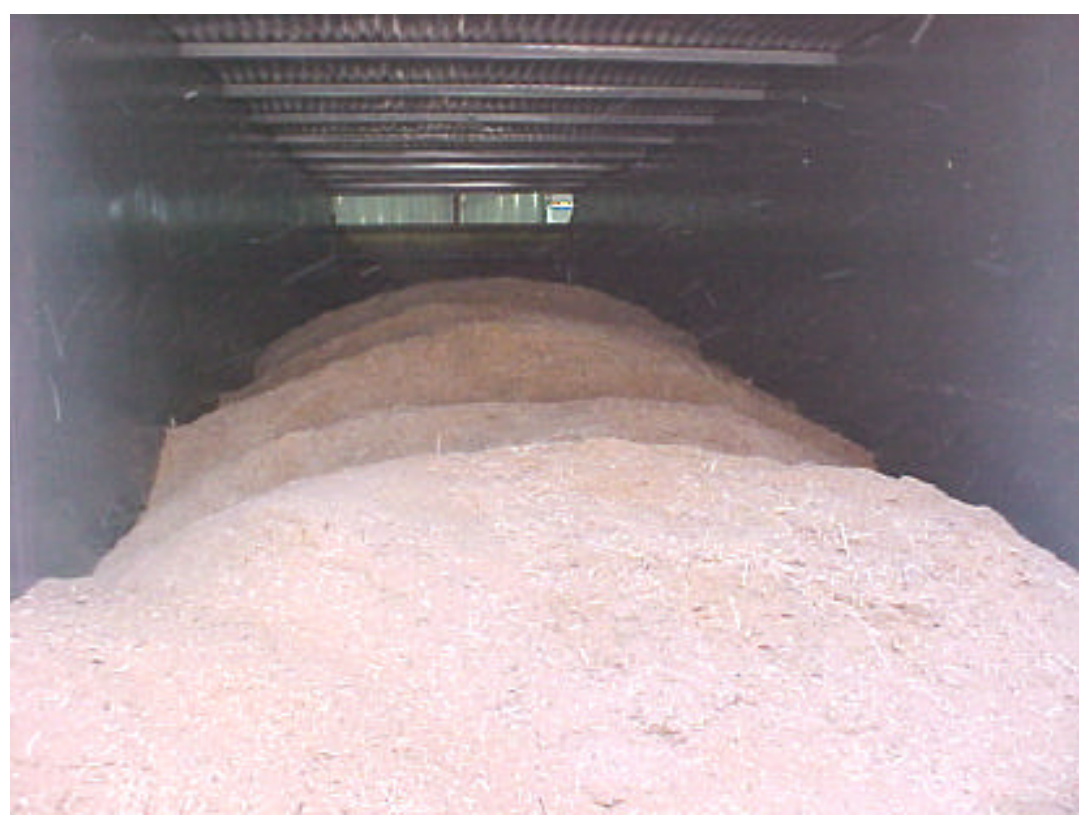

Figure 8-2. Sawdust being transported up the walking floor unloader at Albright

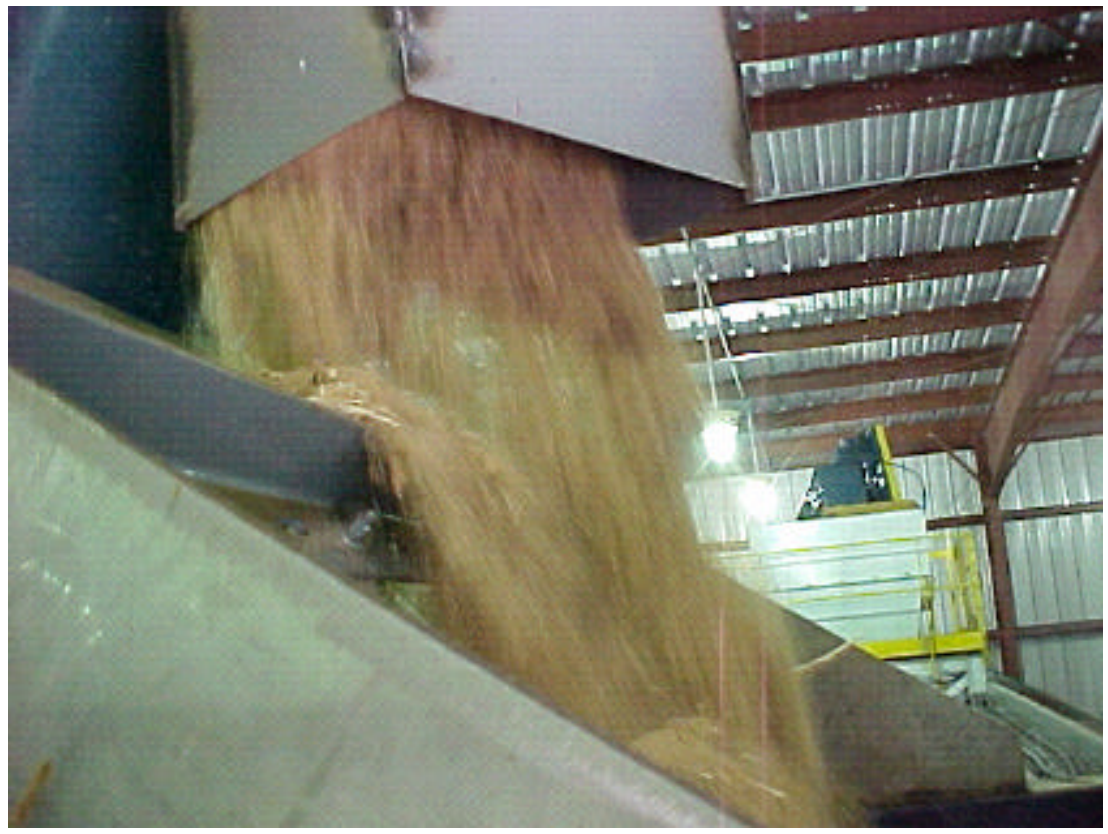


Figure 8-3. Sawdust being discharged onto the disc screen at Albright
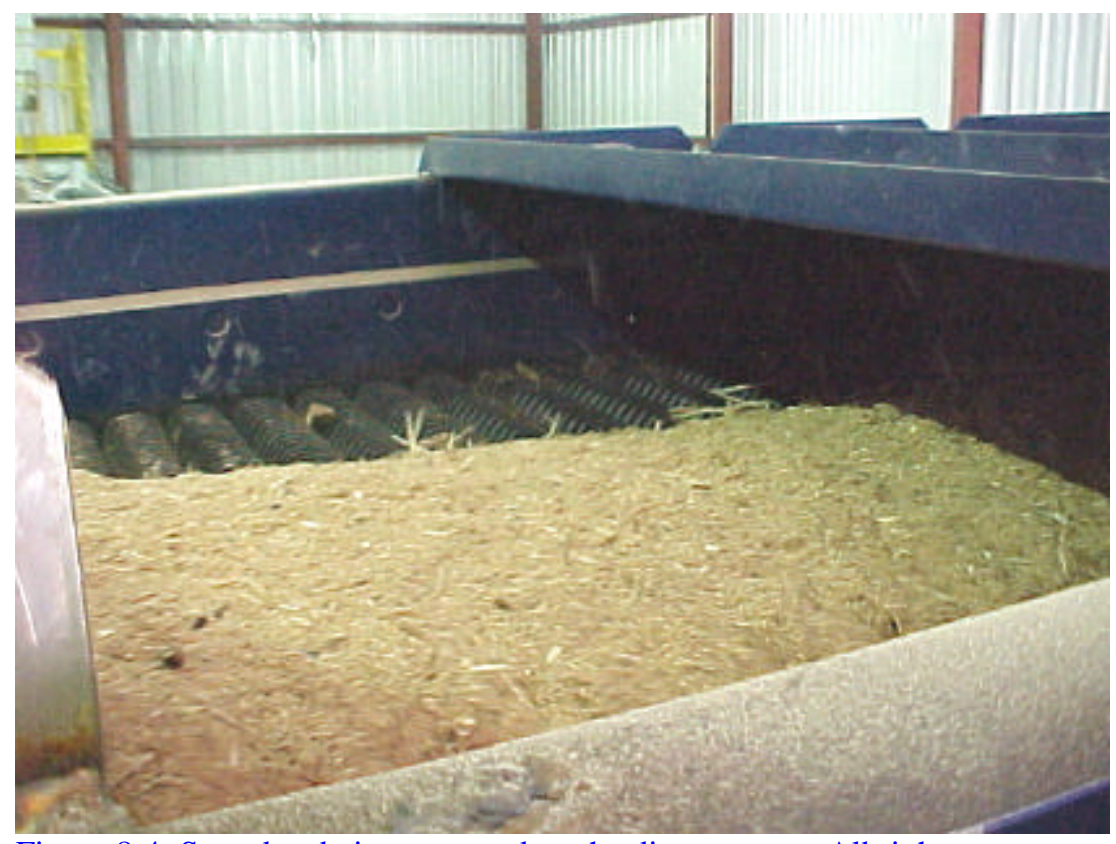

Figure 8-4. Sawsdust being screened on the disc screen at Albright

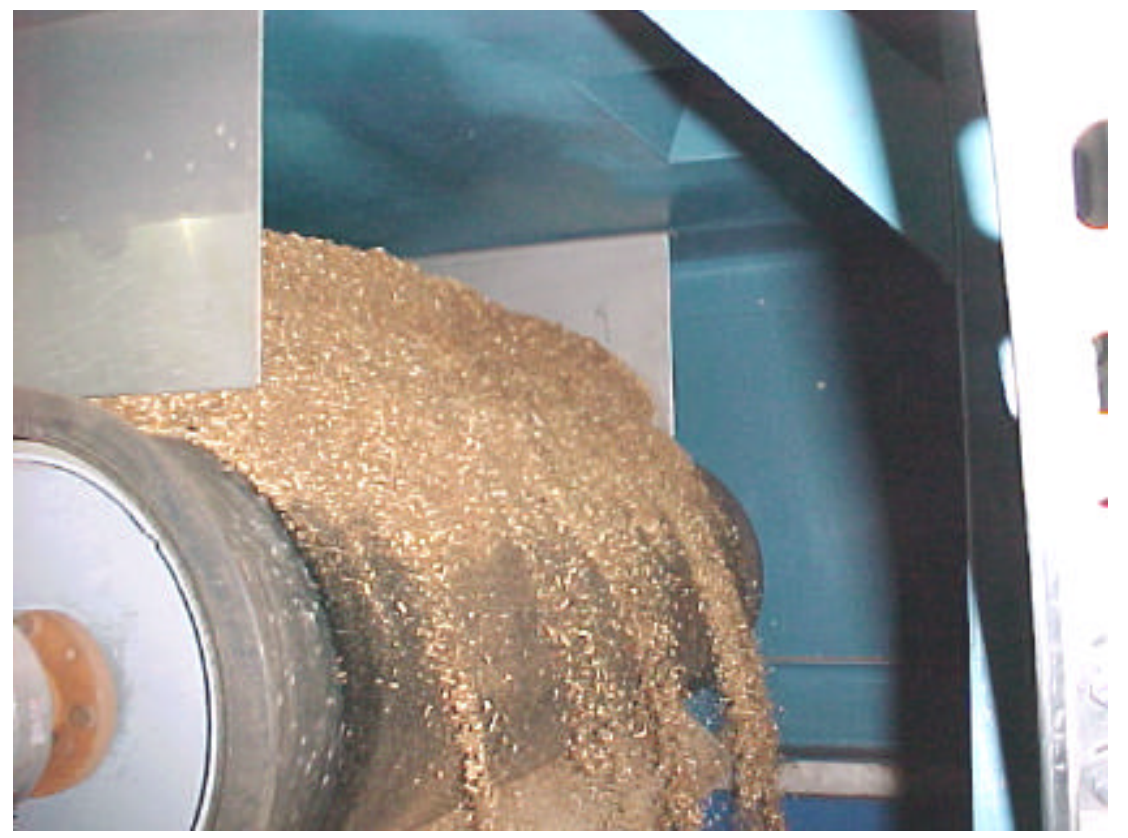


Figure 8-5. Sawdust being metered from the weigh belt to the live bottom bin at Albright

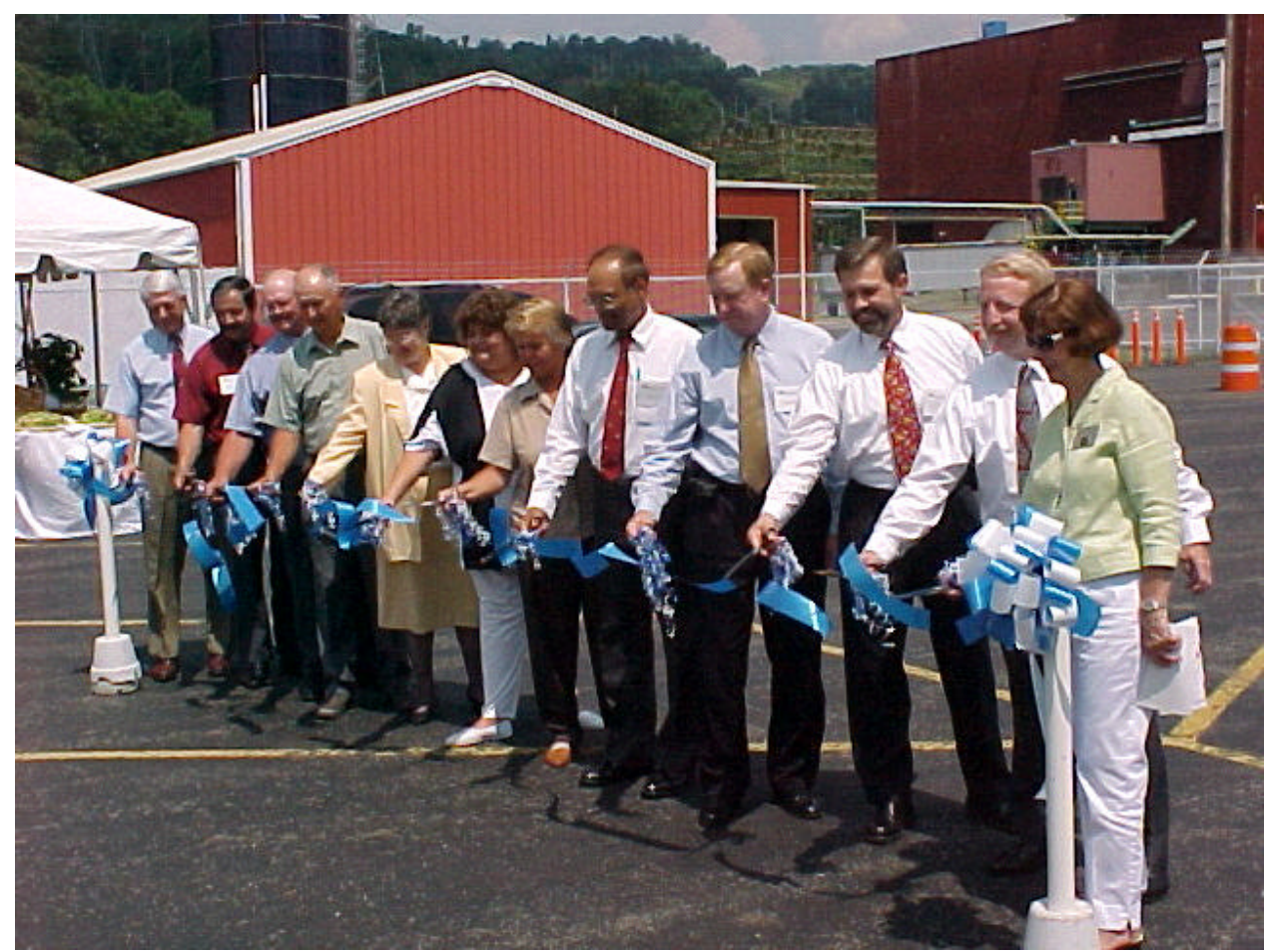

Figure 8-6. The ribbon cutting at the dedication of the Albright cofiring demonstration

\subsection{Data Acquisition and Analysis Methodology}

Data were taken using the PI software on the computer system to complete heat and material balances about the boiler. The PI system and the computer also provided CEMS-based heat input data for the plant along with airborne emissions including $\mathrm{CO}$ (ppmv), opacity (\%), $\mathrm{SO}_{2}\left(\mathrm{ppmv}\right.$ and $\left.\mathrm{lb} / 10^{6} \mathrm{Btu}\right)$, and $\mathrm{NO}_{\mathrm{x}}\left(\mathrm{lb} / 10^{6} \mathrm{Btu}\right)$. In addition to the computer data acquisition system, samples of the fuels, the flyash, and the bottom ash were taken. Portable instrumentation was used at the inlet and outlet of the air heater as a back-up to the computer data acquisition system.

The testing was used to determine the impact of cofiring on the following:

- Plant capacity

- Plant efficiency, measured as boiler efficiency and net station heat rate (NSHR) in Btu/kWh

- Operating Stability

- Airborne emissions as identified above 
Analytically, the heat balance methodology employed a model comparable to that used for calculating heat and material balances at the Willow Island demonstration. The model is shown in Figure 8-7.

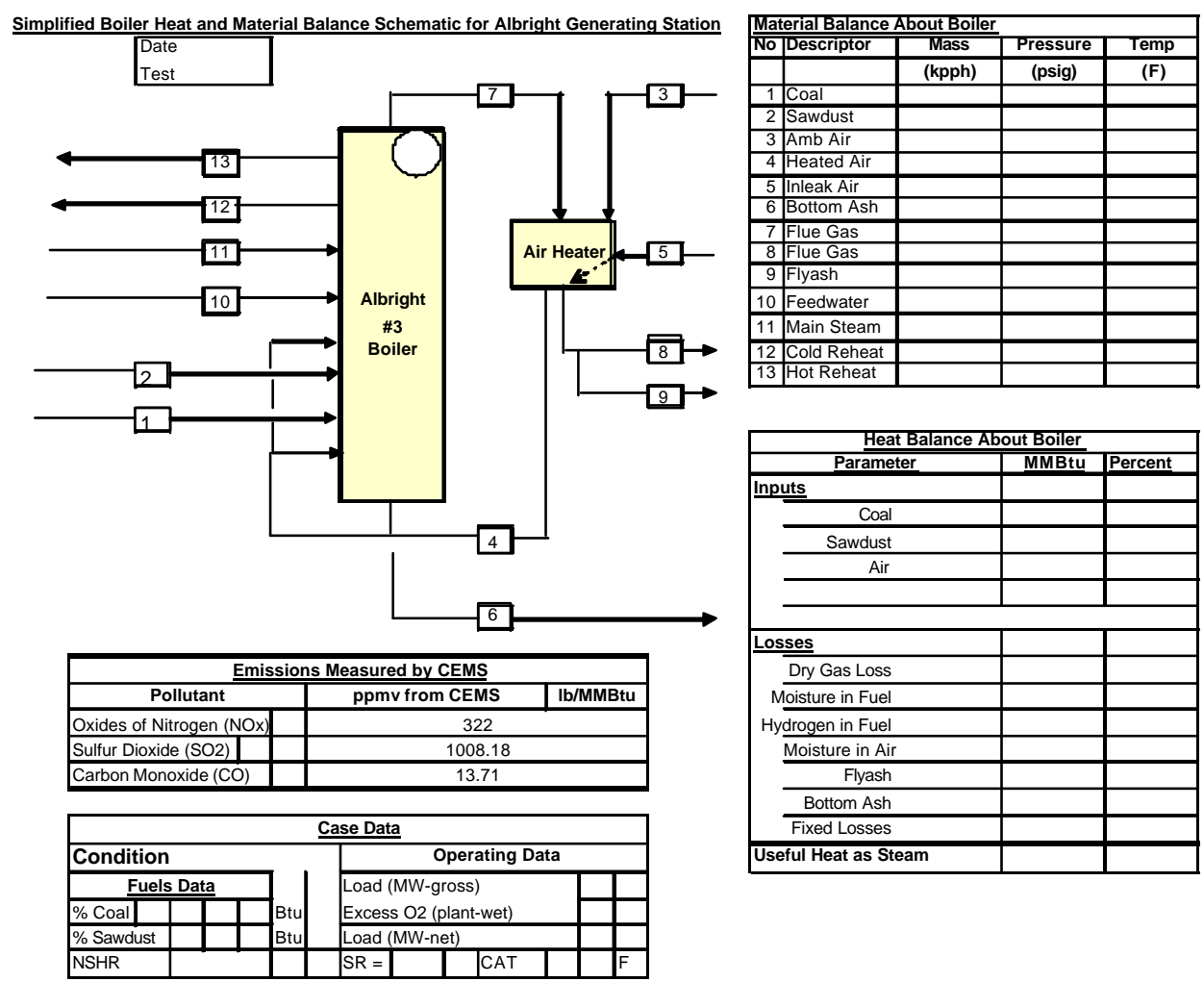

Figure 8-7. The heat and material balance model used for analysis of Albright Generating Station demonstration cofiring data

Heat and material balances were also calculated using an input-output methodology. Eleven heat balances were constructed both on the input-output basis and the heat loss basis. The input-output efficiency percentage calculations were performed as follows:

$$
\left\{\left[\text { MSF x }\left(\mathrm{H}_{\mathrm{ms}}-\mathrm{H}_{\mathrm{fw}}\right)+\mathrm{RHF} \times\left(\mathrm{H}_{\mathrm{hrh}}-\mathrm{H}_{\mathrm{crh}}\right)\right] / \mathrm{HI}_{\mathrm{cems}}\right\} \times 100=\eta
$$

Where MSF is main steam flow (lb/h), $\mathrm{H}_{\mathrm{m}}$ is enthalpy of main steam (Btu/lb), $\mathrm{H}_{\mathrm{fw}}$ is enthalpy of feedwater (Btu/lb), RHF is reheat steam flow $(\mathrm{lb} / \mathrm{h}), \mathrm{H}_{\mathrm{hrh}}$ is enthalpy of hot reheat (Btu/lb), $\mathrm{H}_{\text {crh }}$ is enthalpy of cold reheat (Btu/lb), and $\mathrm{HI}_{\text {cems }}$ is total heat input to the system as measured by the CEMS and reported by the computer data logging system.

Net Station Heat Rates (NSHR) were reported directly from the PI system. These were verified with the heat balance models. 
Emissions reported on the PI data logging system were evaluated against the heat and material balances as shown in Figure 8-7.

\subsection{Operational Results of Cofiring Testing}

Operational results included capacity, efficiency, and operability. These are discussed below. They have been published in several papers (see, for example, Payette, Banfield, Nutter, and Tillman, 2002; Tillman, Payette, and Banfield, 2003).

\subsubsection{Operational Results - Capacity}

The practice of cofiring did not impact boiler capacity. Despite testing during hot days, with temperatures exceeding $90^{\circ} \mathrm{F}$, capacities were not compromised by cofiring. When cofiring at 6 ton/hr, or 10 percent by mass ( 4.7 percent by heat), ID fan amps never exceeded 250 and operational integrity was maintained.

\subsubsection{Operational Results - Efficiency}

Efficiencies were calculated on a heat loss basis and on an input-output basis using the data reported on the PI system data logging computer. The results were then compared. For all of the analyses, fuel and ash quality was considered. Both the coal and sawdust were consistent in quality during the test program, with values as shown previously in Chapter 4 of this report.

The flyash was consistently analyzed for loss on ignition and unburned carbon. Despite cofiring at up to 10 percent by mass, and despite periodically operating the SOFA system in a very open position (Dampers open to $40 \%, 100 \%$, and 100\%), LOI values remained consistently in the $5-7$ percent range. Bottom ash LOI values remained in the 1 percent region during all of the testing.

The standard losses technique employed calculated the useful heat generated in the main steam and the reheat steam; calculated the heat loss in the flue gas, the flyash, the bottom ash, and in other losses (e.g., radiation); and used these to calculate total fuel flow and boiler efficiency.

The total fuel flows shown during the two methods for calculating heat balances were used, on a comparative basis, to determine the closure for the heat loss method results. Closure ranged from 93.8 percent to 97.5 percent. There is considerable overall agreement between the two methods for determining total heat input although the heat balances calculated by the losses method always produce a lower value than determined by the CEMS.

The parameters used for the losses determination yielded the following typical values:

- Excess $\mathrm{O}_{2}: 2.8-3.5$ percent (total basis), centering around 3.0 
- Air heater exit temperature: $335-345^{\circ} \mathrm{F}$

- Air heater in-leakage: $10-13$ percent

- Flyash LOI: $5 \%$

Due to its precision, and the bases of calculation, we have placed more significance on the heat losses calculations than the input-output calculations for determining efficiency parameters. Using the conventional heat losses calculations, the impacts of cofiring on boiler performance can be seen. For analytical purposes, Figure 13 compares cofiring on a mass basis to cofiring on a heat input basis. For purposes of calculating cofiring percentages, the following equation holds:

$$
\text { COFIRE }(\text { mass \%) = Sawdust }(\text { ton/h) } \times 1.69
$$

Following the comparison of cofiring on a heat and mass percentage basis, Figures 8-8 8-11 present the major losses categories. Figure 8-8 presents the impact of cofiring on air heater exit temperature. Note that, because the transport air for the sawdust is ambient air rather than preheated air, the air heater exit temperature rises with the practice of cofiring. The data suggest that at $6-10^{\circ} \mathrm{F}$ rise is common with the practice of cofiring, depending upon the cofiring percentage. This was first reported at the Blount St. Station cofiring tests of switchgrass.

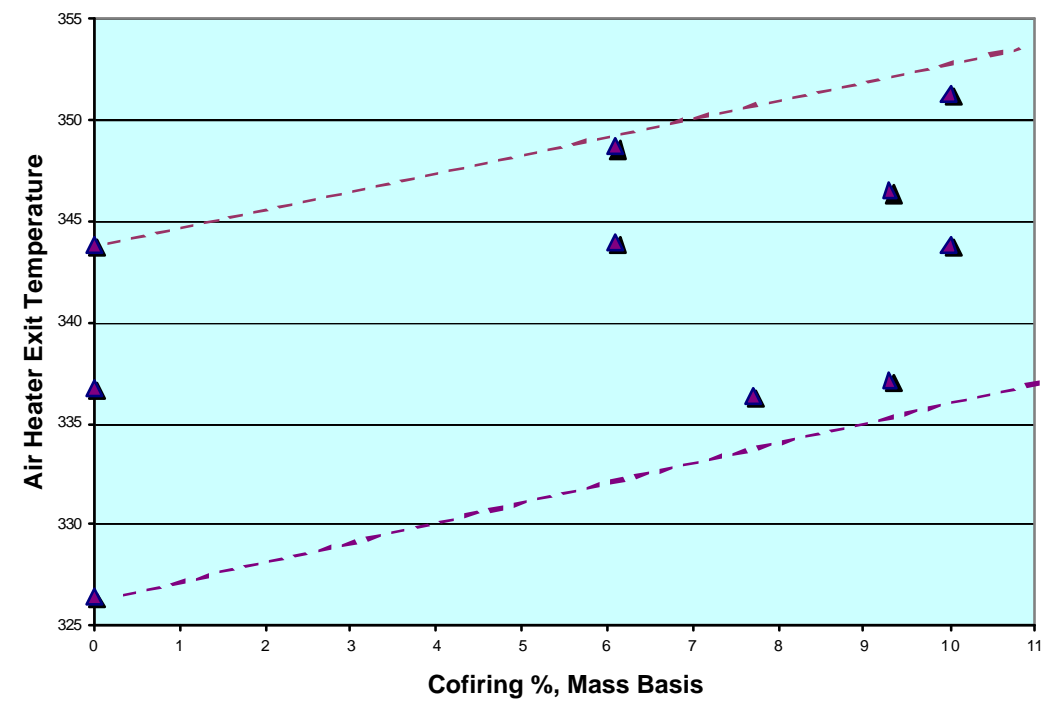

Figure 8-8. Influence of cofiring sawdust on air heater exit temperature

Figure 8-9 presents dry gas losses. Note that there is not a good correlation between cofiring and dry gas loss. While the air heater exit temperature increases, there is not a consistent pattern of excess $\mathrm{O}_{2}$ associated with cofiring. Cofiring does not increase the 
excess $\mathrm{O}_{2}$ requirement; consequently it does not govern the major parameter influencing dry gas loss.

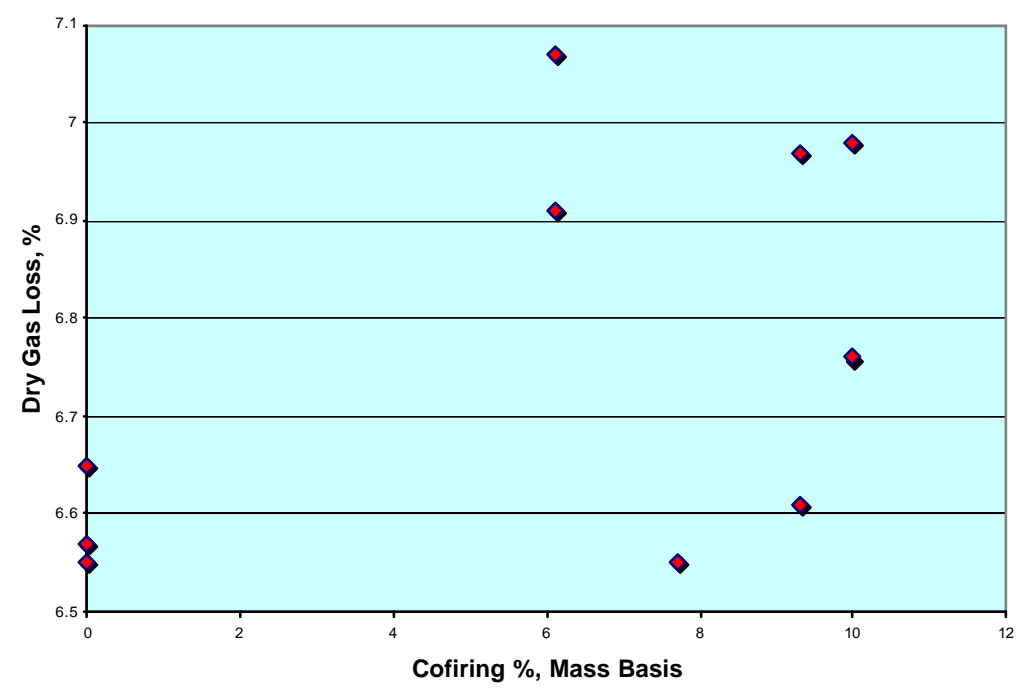

Figure 8-9. Dry gas loss associated with biomass cofiring at Albright Generating Station

Figure 8-10 presents loss associated with moisture in the fuel and Figure 8-11 presents loss associated with hydrogen in the fuel. These are the major determinants of the loss.

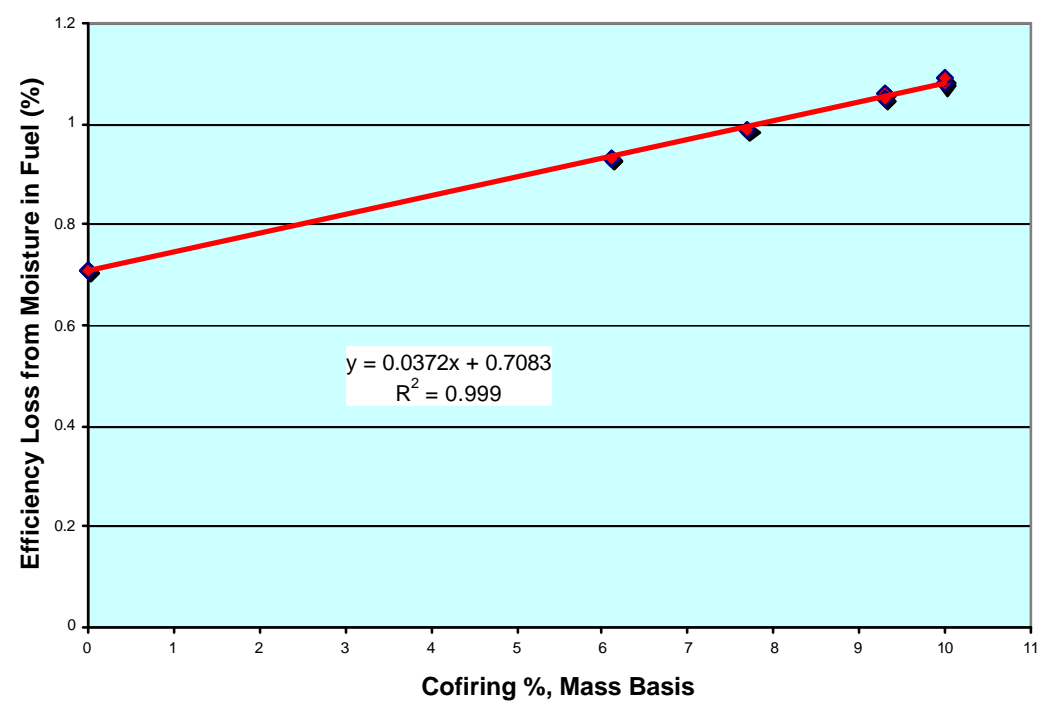

Figure 8-10. Influence of cofiring on loss from moisture in the fuel at Albright 


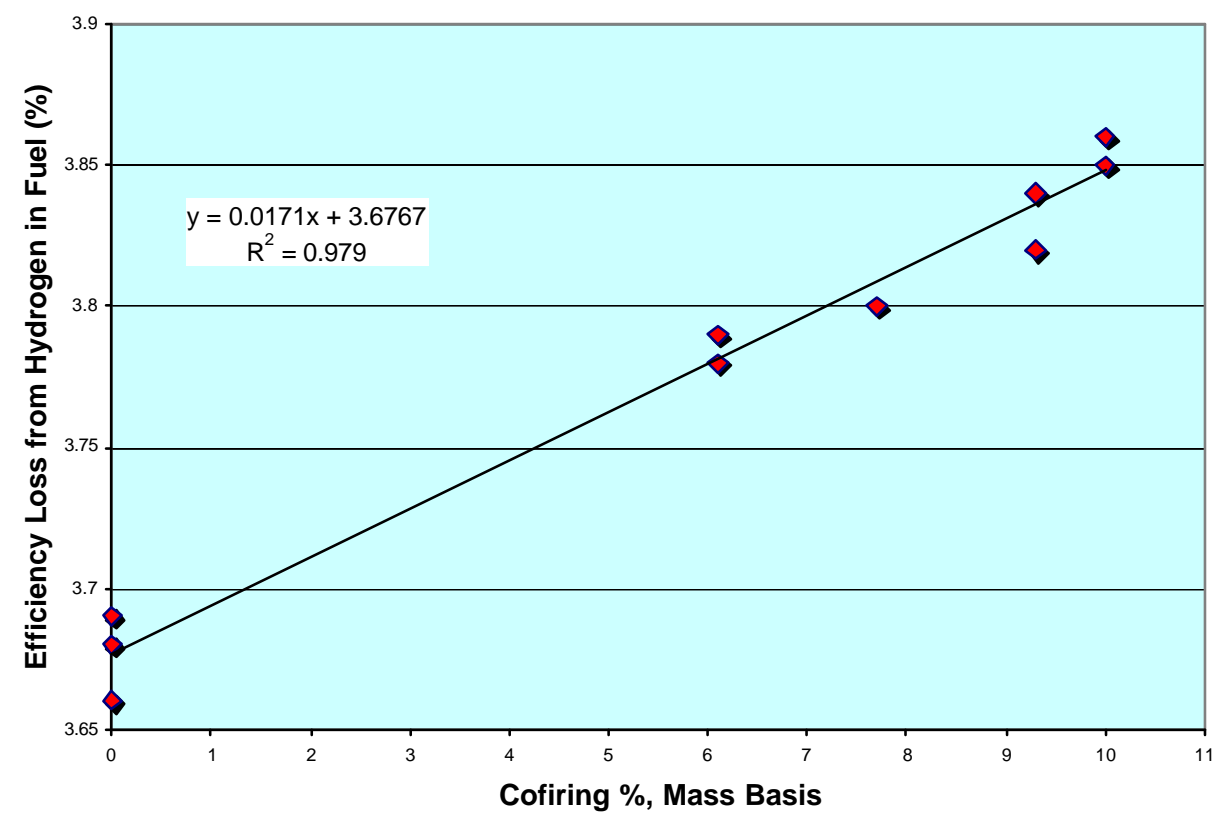

Figure 8-11. Influence of hydrogen in the fuel on efficiency loss at Albright

The efficiency calculated by the losses methodology yielded a generalized equation to show the impact of biomass cofiring.

$$
\eta=\mathrm{K}-0.136\left(\% \mathrm{~W}_{\mathrm{m}}\right)+0.0064\left(\mathrm{~W}_{\mathrm{m}}{ }^{2}\right)
$$

Where $\mathrm{K}$ is the efficiency when firing coal alone and $\mathrm{Wm}$ is the mass percentage of sawdust cofired into the boiler. The $\mathrm{r} 2$ for this equation is 0.77 , indicating that there are numerous other factors involved including load and the excess $\mathrm{O}_{2}$ associated with various loads, the use of the separated overfire air (SOFA) system and the consequent unburned carbon in the flyash, and other factors.

The impact of cofiring on net station heat rate (NSHR), however, is not significant at the Albright Generating Station boiler \#3. NSHR can be calculated from either the heat balance calculations or the CEMS data.

The driver on the net station heat rate, as calculated from the CEMS data, is strictly the water rate-lbs of main steam $/ \mathrm{kWh}$ - expressed on either a gross or net basis. The lack of cofiring influence on NSHR res ults from this factor. Both gross and net water rates are a function of main steam temperature as shown in Figure 812. These data indicate an operating concern with main steam temperatures. Further, water rates are driven by condenser performance and the temperature of the river water. This factor is totally unrelated to biomass cofiring. 


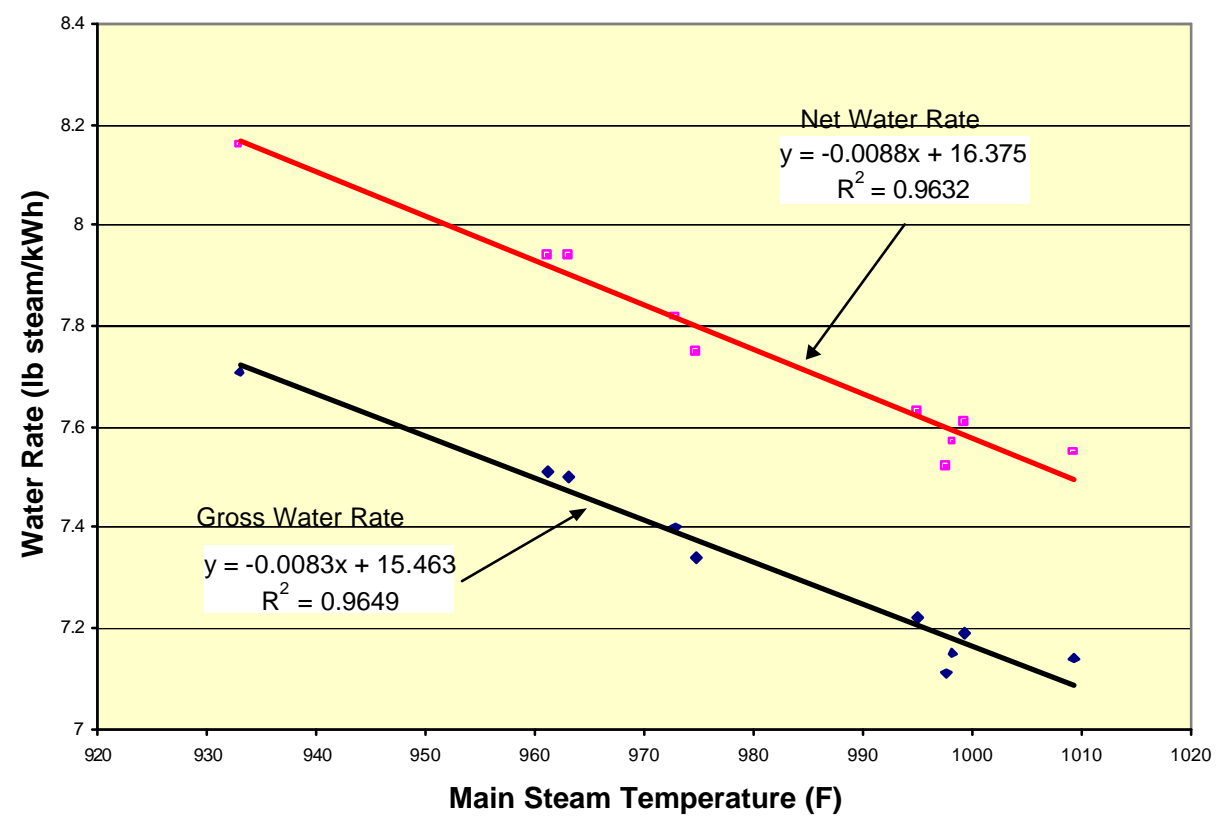

Figure 8-12. Gross and Net Water Rates as a Function of Main Steam Temperature at Albright Generating Station Boiler \#3.

If the NSHR values are obtained from the heat balances as described above, then the practice of cofiring does have a minor impact on NSHR. Equations 8-2 through 8-4 are really three forms of the same equation. They document that each ton of sawdust cofired increased the NSHR by $<6 \mathrm{Btu} / \mathrm{kWh}(<35 \mathrm{Btu} / \mathrm{kWh}$ at 10 percent cofiring). Again the water rate was more influential. Each of these equations has a coefficient of determination, $\mathrm{r}^{2}$, of 0.918 . The significance determinants for these equations are virtually identical, and are shown in Table 5.

$$
\begin{aligned}
& \mathrm{NSHR}=\mathrm{K}^{\prime}+353.9(\mathrm{NWR})+5.93\left(\mathrm{C}_{\mathrm{t} / \mathrm{h}}\right) \\
& \mathrm{NSHR}=\mathrm{K}^{\prime}+355.4(\mathrm{NWR})+7.16\left(\mathrm{C}_{\mathrm{m} \%}\right) \\
& \mathrm{NSHR}=\mathrm{K}^{\prime}+355.1(\mathrm{NWR})+16.34\left(\mathrm{C}_{\mathrm{h} \%}\right)
\end{aligned}
$$

Where $\mathrm{K}^{\prime}$ is the base net station heat rate for the unit before considering the water rate or fuel impacts, NWR is net water rate in $\mathrm{lb}$ main steam/kWh net power output, $\mathrm{C}_{\mathrm{k} / \mathrm{h}}$ is cofiring expressed in ton/hr when firing at $130 \mathrm{MW}$ (net), $\mathrm{C}_{\mathrm{m}} \%$ is cofiring expressed on a mass percentage basis, and $\mathrm{C}_{\mathrm{h}}$ is cofiring expressed on a heat input percentage basis. The term K' is commonly 7900 - 7950 for most pulverized coal boilers of the vintage and steam conditions associated with the Albright Generating Station Unit \#3. 
Table 5. Probabilities That Terms in Equations 8-2 through 8-4 Can Occur Randomly(*)

\begin{tabular}{|c|c|c|}
\hline Item & Descriptor & Probability \\
1 & Equation in Total & 0.00016 \\
\hline 2 & Intercept & $4.73 \times 10-8$ \\
\hline 3 & Water Rate & $6.08 \times 10-5$ \\
\hline 4 & Cofiring Level (by any definition) & 0.0105 \\
\hline
\end{tabular}

Note: 1-probability is a measure of significance

The consequence of equations 82 through $8-4$ is that al 0 percent cofiring on a mass basis increases the net station heat rate by a maximum of $\sim 72 \mathrm{Btu} / \mathrm{kWh}$. The calculated influence of cofiring is an increase of $35 \mathrm{Btu} / \mathrm{kWh}$ in the NSHR, when cofiring at 10 percent; this represents an increase of $3.5 \mathrm{Btu} / \mathrm{kWh}$ for every percentage sawdust cofiring. The influence of the main steam temperature and condenser performance, and the consequent water rate, far outweighs the influence of cofiring. This can be seen explicitly from equation 85

$$
\text { NSHR }=\text { K" }-3.29(\mathrm{MST})+10.28\left(\mathrm{C}_{\mathrm{m} \%}\right)
$$

Where $\mathrm{K}$ " is a constant, MST is main steam temperature in ${ }^{\circ} \mathrm{F}$. Every lost degree creates an increased NSHR of $3.29 \mathrm{Btu} / \mathrm{kWh}$. This phenomenon is common to all fossil fired boilers in the utility industry. Consequently, every percentage of cofiring on a mass basis is equal to $3^{0} \mathrm{~F}$ main steam temperature. The $\mathrm{r}^{2}$ for this equation is 0.907 and the probabilities that any term can occur randomly are all $<0.003$.

\subsection{Emissions Consequences of Cofiring at Albright Generating Station}

The emissions consequences for cofiring at Albright Generating Station are quite favorable. Figures 8-13 through 8-17 document emissions impacts with respect to carbon monoxide (CO), opacity, $\mathrm{SO}_{2}$, and $\mathrm{NO}_{x}$. The $\mathrm{CO}$ and $\mathrm{SO}_{2}$ emissions are reported in ppmv. The opacity emissions are reported in percent. The $\mathrm{NO}_{\mathrm{x}}$ emissions are reported in $\mathrm{kg} / \mathrm{MJ}$ and $\mathrm{lb} / 10^{6} \mathrm{Btu}$.

Note that there is no apparent impact of cofiring on either $\mathrm{CO}$ or opacity. $\mathrm{SO}_{2}$ appears to decrease as a function of cofiring level, although there is variability in the results caused by variability in the coal. $\mathrm{NO}_{\mathrm{x}}$ reductions are strong. They can also be described by regression equation as shown below $\left(r^{2}=0.868\right.$ over 68 observations):

$$
\mathrm{NO}_{\mathrm{x}}=0.361-0.0043\left(\mathrm{C}_{\mathrm{m} \%}\right)+0.022\left(\mathrm{EO}_{2} \%\right)-0.00055(\mathrm{SOFA})
$$

Where $\mathrm{NO}_{\mathrm{x}}$ is measured in $\mathrm{lb} / 10^{6} \mathrm{Btu}, \mathrm{EO}_{2} \%$ is percent excess oxygen in the flue gas leaving the furnace (total basis), and SOFA is the total position of the three SOFA damper systems. Alternatively, the equation is 
Where $\mathrm{NO}_{\mathrm{x}}$ is measured in $\mathrm{kg} / \mathrm{GJ}$.

The SOFA values used to create this equation ranged from $15 \%$ to $240 \%$. There are 3 levels of SOFA at Albright Unit \#3, and each level can be opened up from 0 to 100 percent. The practical consequence of the cofiring tests was a 15 percent $\mathrm{NO}_{\mathrm{x}}$ reduction-and consistent measurement of $\mathrm{NO}_{\mathrm{x}}$ levels at $0.26 \mathrm{lb} / 10^{6}$ Btu when cofiring with the SOFA dampers set at 40\%/100\%/100\%.

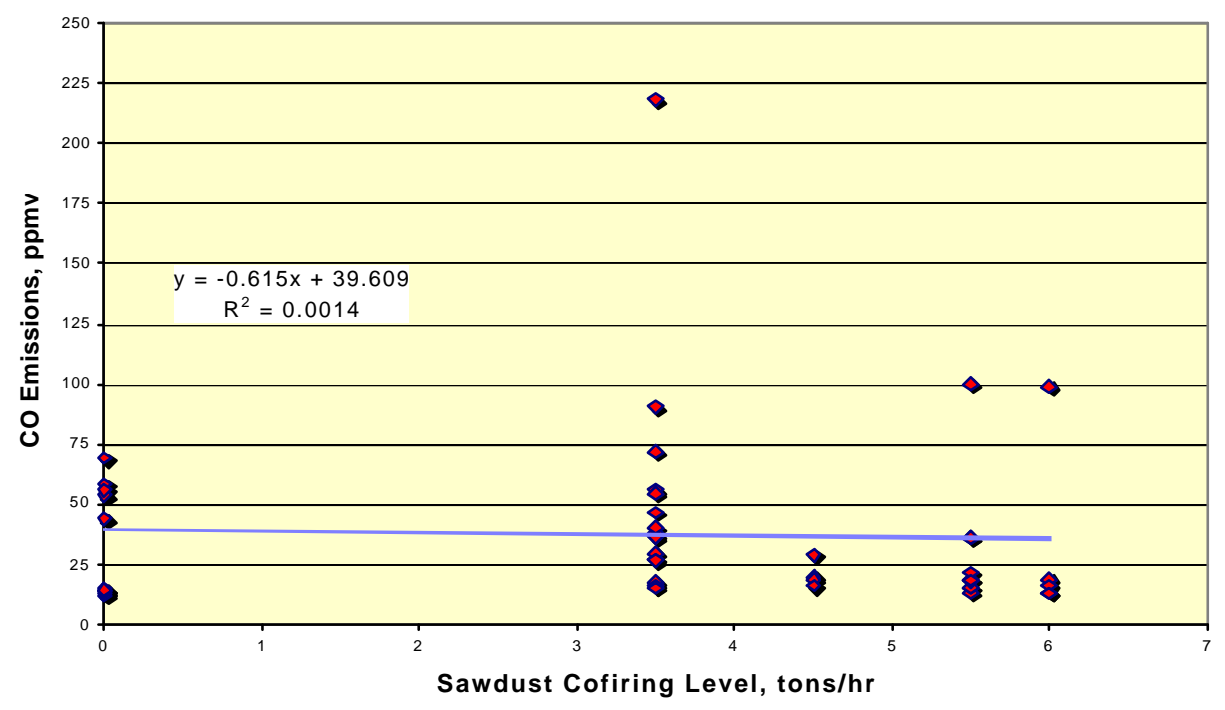

Figure 8-13. Impact of Cofiring on CO Emissions at Albright Generating Station 


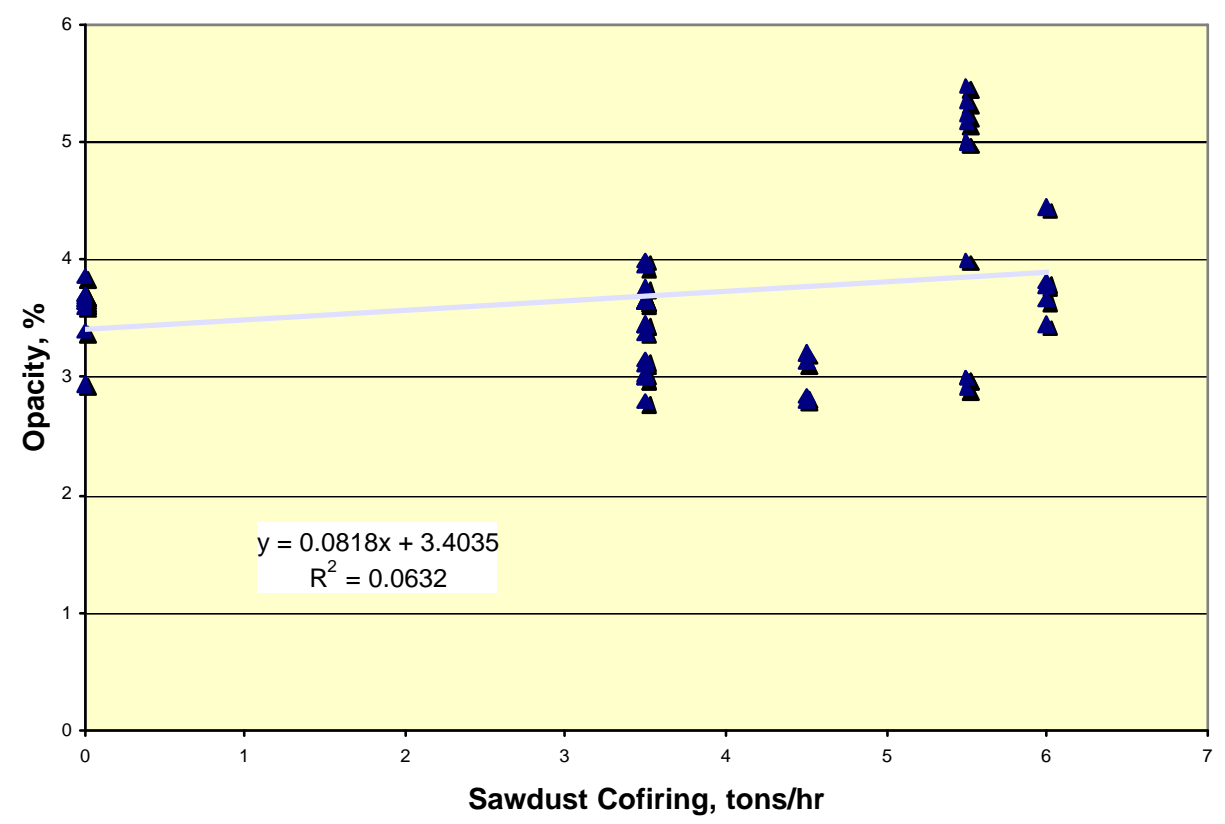

Figure 8-14. Impact of Cofining on Opacity at Albright Generating Station

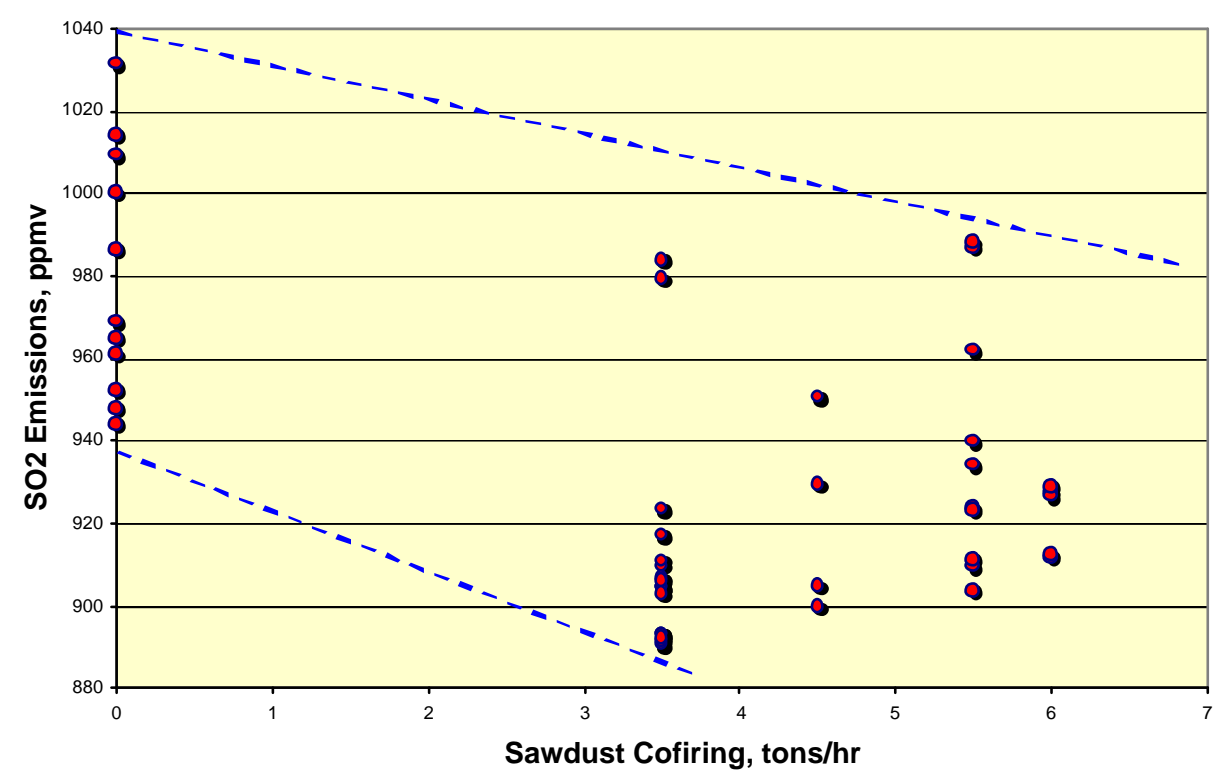

Figure 8-15. Impact of Cofiring on $\mathrm{SO}_{2}$ Emissions at Albright Generating Station 


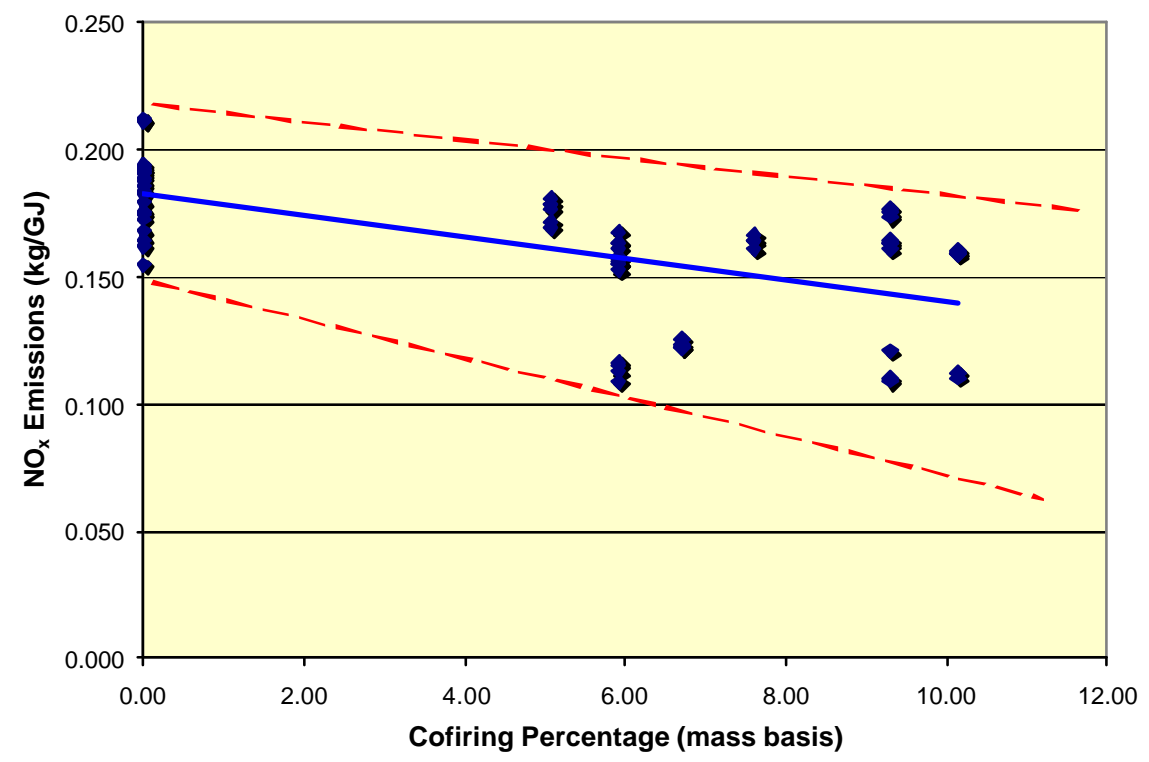

Figure 8-16. $\mathrm{NO}_{\mathrm{x}}$ emissions as a function of cofiring at Albright $(\mathrm{kg} / \mathrm{GJ})$

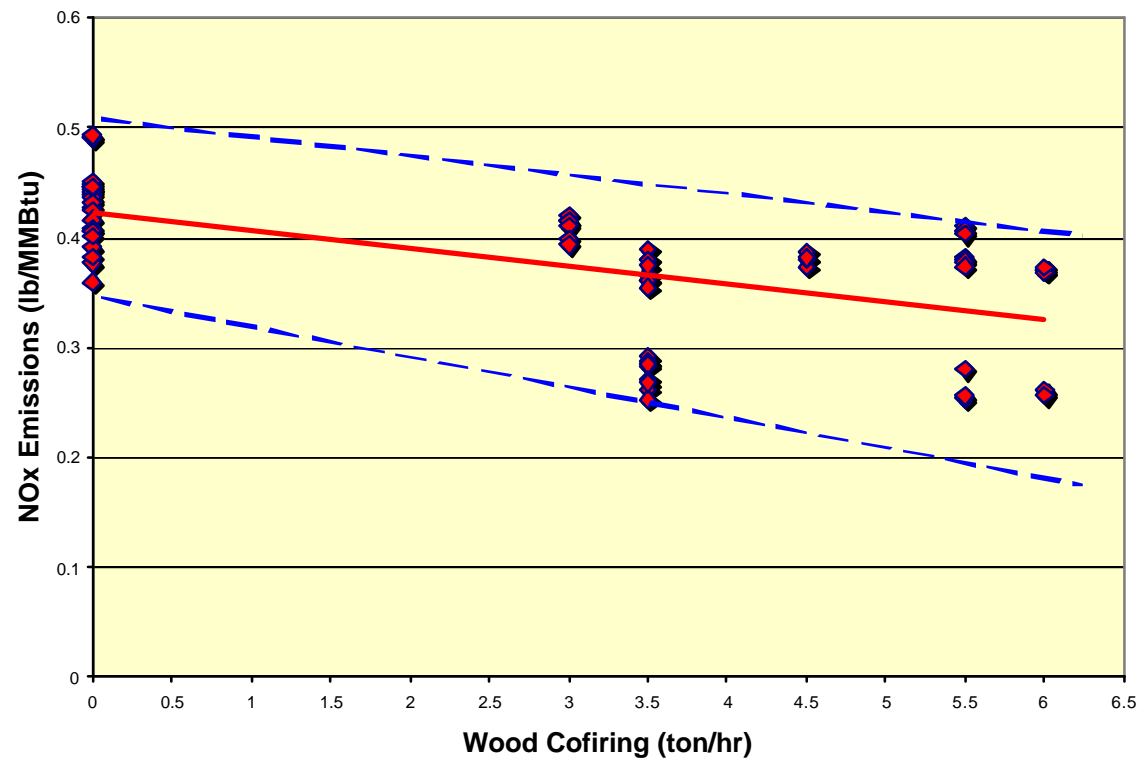

Figure 8-17. Impact of Cofiring on $\mathrm{NO}_{\mathrm{x}}$ Emissions at Albright $\left(\mathrm{lb} / 10^{6} \mathrm{Btu}\right)$ 
The probabilities that the terms in equations [8-6 and 87] could have occurred as a random event are as follows:

- Equation in total: $4.2 \times 10^{-28}$

- Intercept: $2.3 \times 10^{-24}$

- Cofiring percentage: $1.2 \times 10^{-5}$

- Excess oxygen percentage: $5.9 \times 10^{-4}$

- SOFA position: $5.0 \times 10^{-22}$

The comparison between observed and predicted NOx emissions, based upon Equation 86 , is shown in Figure 8-18.

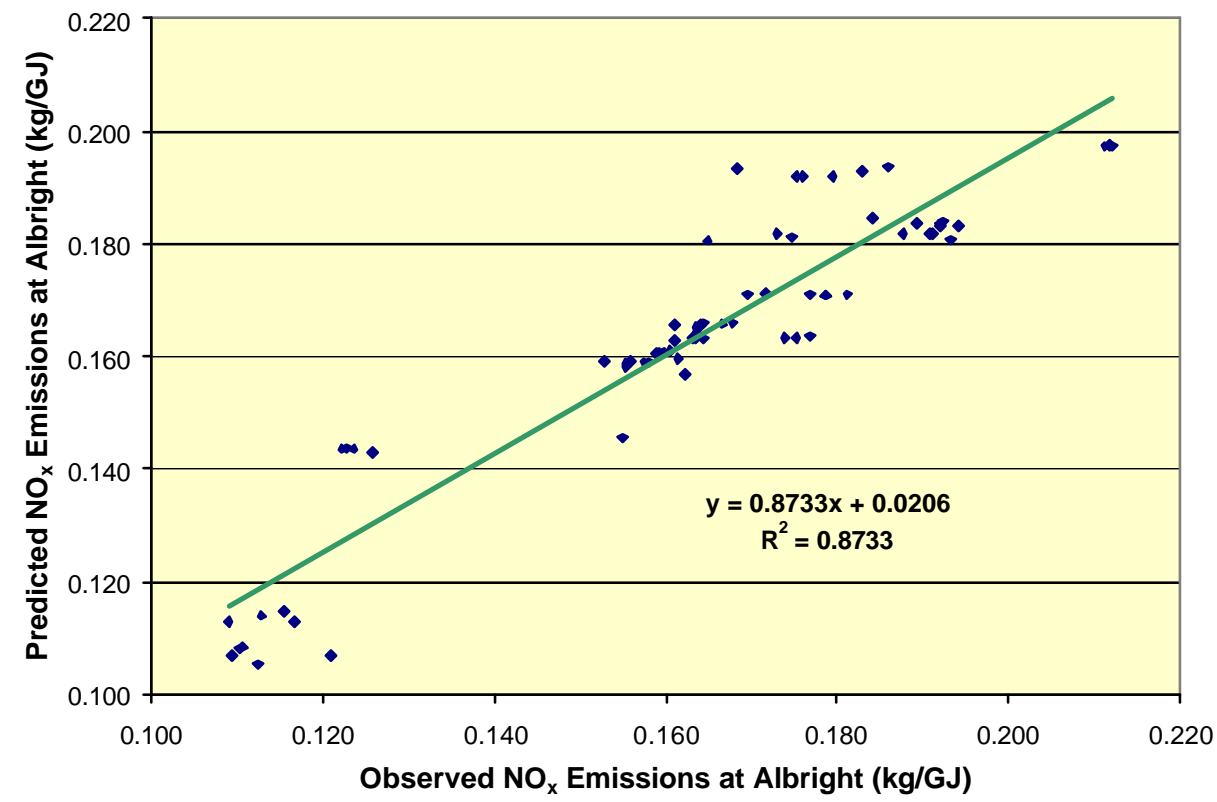

Figure 818. Comparison of observed and predicted NOx emissions at Albright based upon equations [8-6] and [8-7]

What becomes interesting about the $\mathrm{NO}_{\mathrm{x}}$ results is the interplay between the cofiring itself and the use of the SOFA system. Cofiring reduced NOx emissions directly by $0.043 \mathrm{lb} / 10^{6} \mathrm{Btu}$ when cofiring at 10 percent sawdust. This represents a 12 percent reduction in NOx emissions as a consequence of 10 percent biomass cofiring on a mass basis, or $\sim 4.5$ percent cofiring on a heat input basis. However the SOFA system, opened to 240 percent, reduced $\mathrm{NO}_{\mathrm{x}}$ emissions by $0.13 \mathrm{lb} / 10^{6} \mathrm{Btu}-\mathrm{a}$ reduction of 36 percent. Later testing opening the SOFA system to 300 percent-opening the SOFA dampers wide open on all 3 levels - reduced NOx emissions by $0.17 \mathrm{lb} / 10^{6} \mathrm{Btu}-\mathrm{a}$ reduction of 47 percent. When the SOFA dampers were opened wide firing only coal, however, the unburned carbon in the flyash increased to $10-12$ percent. However the addition of $8-$ 
10 percent sawdust in the fuel mix permitted opening up the SOFA dampers wide open while holding unburned carbon in flyash to $5-7$ percent. The cofiring system made the SOFA system more effective and more usable. The cofiring system permitted reducing NOx emissions by over 30 percent without experiencing unacceptable unburned carbon in the flyash.

The dominant mechanism associated with $\mathrm{NO}_{\mathrm{x}}$ reductions from cofiring in T-fired boilers can loosely be described as volatile flooding. Volatile compounds and fragments released by rapid devolatilization of the sawdust in the center of the fireball scavenge NOx formed during the combustion process. More significantly, however, the high volatile/fixed carbon ratio of the biomass and the rapid devolatilization contributes to increased carbon conversion in the flame, thereby reducing the unburned carbon carried over when using the SOFA system. The overall mechanism, then, is support for deeper staging of the combustion process without encountering difficulties associated with unburned carbon in the flyash and the associated losses with that phenomenon.

A second, supporting mechanism also may be operating to reduce NOx emissions. The separate injection systems relieve some of the load on the mills. With lower production requirements at the pulverizers, those mills can produce a finer coal product. The improved mill fineness may also contribute modestly to the $\mathrm{NO}_{\mathrm{x}}$ reduction.

Mercury emissions also were reduced by cofiring. The sawdust obtained for the Albright Generating Station demonstration had a mercury concentration of $0.003-0.009 \mathrm{mg} / \mathrm{kg}$ mercury. The coal burned at Albright had a mercury concentration of $0.15 \mathrm{mg} / \mathrm{kg}$ of mercury. Even compensating for the reduced heating value of the sawdust, this represents a substantial potential for emissions reduction.

Greenhouse gas emissions are also reduced by cofiring. The practice of firing 10 percent (mass basis) sawdust with coal is equivalent to firing 6 tons/hr of biomass. Firing 6 tons/hr of sawdust directly reduces fossil $\mathrm{CO}_{2}$ emissions by 6.3 tons/hr and, if methane generation from disposed of biomass is included, the total fossil $\mathrm{CO}_{2}$ equivalent reduction is $\sim 19$ tons $/ \mathrm{hr}$.

\subsection{Hour Testing at Albright Generating Station}

During the period of October 1, 2002 - October 5, 2002, Allegheny ran a 100 hour test of the Albright demonstration system to evaluate its commercial potential. The test concluded 100 hours of operation in 104 clock hours and was considered successful. During this test numerous experiments were conducted documenting that the system could be operated over a broad range of capacities. Further, the emissions reductions measured during the short term tests were repeated and documented. It was during these tests that the SOFA dampers were repeatedly opened wide and $\mathrm{NO}_{\mathrm{x}}$ emissions of 0.108 $\mathrm{kg} / \mathrm{GJ}\left(0.25 \mathrm{lb} / 10^{6} \mathrm{Btu}\right)$ were repeatedly achieved cofiring $5.0-5.5$ tonnes $/ \mathrm{hr}(5.5-6.0$ tons/hr) of sawdust. 


\subsection{Conclusions}

The data developed from the Albright Generating Station cofiring test and demonstration strongly indicate that cofiring has had the following results:

- Cofiring has caused no loss of capacity

- Cofiring has caused a very modest decrease in boiler efficiency, shown only with theoretical calculations

- The decrease in boiler efficiency translates into a very modest decrease in NSHR when cofiring at 10 percent (mass basis)

- Cofiring has had a favorable impact on $\mathrm{SO}_{2}$ and $\mathrm{NO}_{\mathrm{x}}$ emissions without negatively impacting $\mathrm{CO}$ or opacity.

Cofiring has been shown to be a potentially useful approach to pollution management at the Albright Generating Station. Further, cofiring of sawdust with separate injection has been shown to be a useful technique for using biomass in T-fired boilers. 


\section{Conclusion: The Demonstrated Impacts of Cofiring at Willow Island and Albright Generating Stations}

The cofiring demonstrations conducted at the Willow Island Generating Station and the Albright Generating Station have identified key information including aspects of system design and construction, operations, and environmental protection. The information obtained, or "lessons learned" have been presented by Tillman, Payette, and Banfield (2003) and are discussed below.

\subsection{Design and Construction}

The design and construction of cofiring systems requires similar equipment for many aspects of the project regardless of whether the woody biomass is to be blended with coal on the main fuel belt leading to the bunkers, or whether the biomass is to be separately injected into the boiler. Those aspects that are similar include:

- Biomass fuel receiving

- Biomass fuel processing (e.g., screening, grinding)

- Biomass fuel storage

The differences are in the delivery of the sawdust to the boiler. For blending on the belt, delivery is simple; however the rate of biomass delivery can be very high to match the bunker loading schedules typically employed in power plants. For separate injection, the systems are more complex, but have less delivery capacity.

The designs used for the Allegheny demonstrations were reasonably automated, with controls in the control rooms. During the demonstration phases of the program these systems required some personnel attention when trucks delivered sawdust; however this need may be mitigated over time with operating experience.

The designs developed for Allegheny had capital costs of $\$ 180 / \mathrm{kW}$ - $\$ 270 / \mathrm{kW}$ for the cyclone boiler, depending upon the method of calculation. The design developed for separate injection in the Albright boiler had an associated capital cost of $\$ 300 / \mathrm{kW}$ assuming new construction. In both cases the capital costs were reduced by limiting sawdust delivery to walking floor vans. The walking floor unloader was designed with the intent of accepting coal trucks; however as figures 9-1 and 9-2 show, testing of this concept proved infeasible. The tailgate of the coal truck was too close to the walking floor, and the result would have been sawdust dumped on the ground outside the facility.

Sawdust costs could have been reduced by $\sim 2 /$ ton if the units were equipped to accept chip vans and trailer dumps. Such reductions in sawdust cost would have come at an increase in capital costs, however; a trailer dump that lifts the entire trailer, common in the forest products ind ustry, would have carried with it an incremental installed capital cost of $\sim \$ 250,000$ or more. Such a system also would have required additional real estate that was not available at either site. 


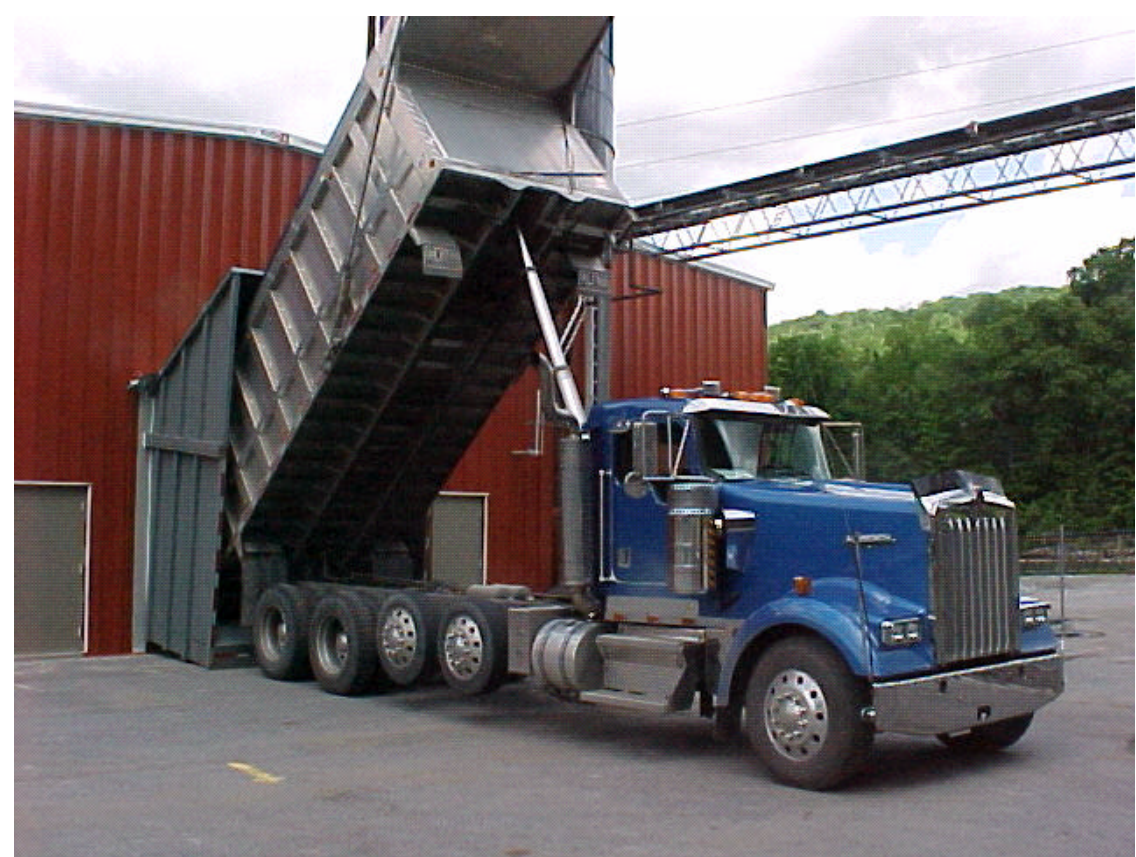

Figure 9-1. Testing a coal truck at the Albright demonstration site.

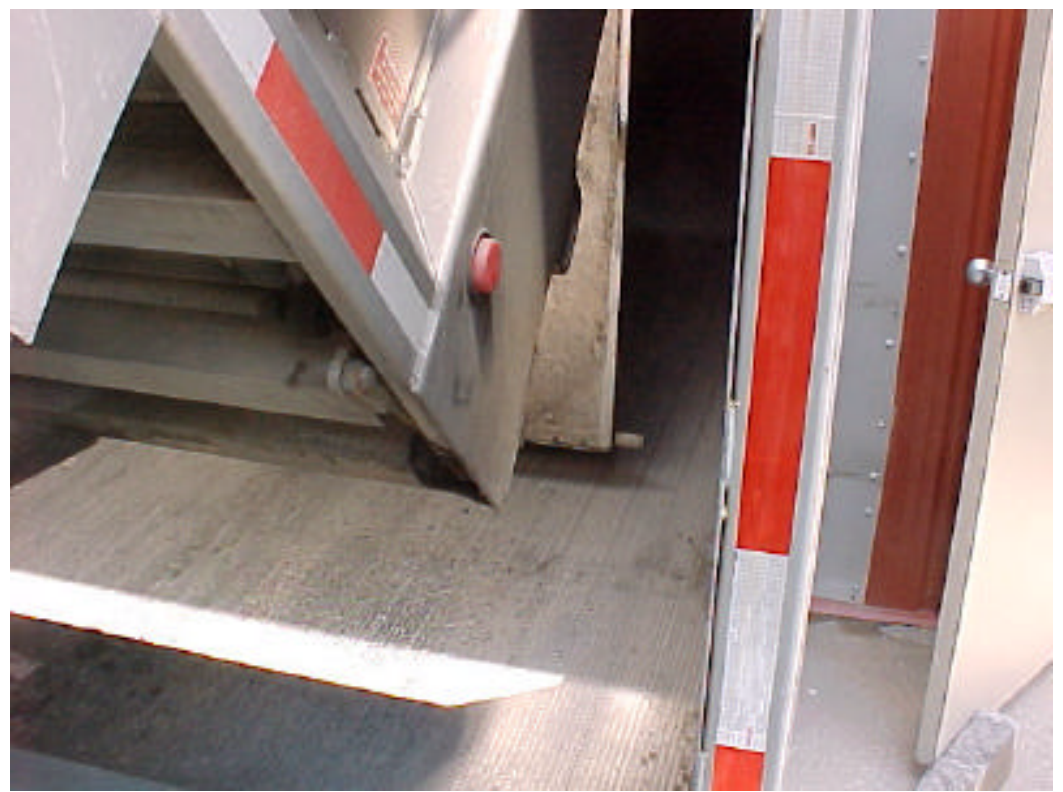

Figure 9-2. The lack of tailgate clearance for coal trucks at the Albright demonstration 
Capital costs could have been further decreased by substituting labor for capital.

Previous tests and demonstrations such as the Bailly demonstration substituted labor for capital due to the nature of the project. In today's utility world, use of additional labor is not a favored technique.

There appears to be little impact on the project by using either mechanical or pneumatic conveying systems. This is an area where plant preference dominates.

The separate injection systems using blowers for each injection point are somewhat more capital intensive than those using single transport pipes and splitter boxes. Similarly, capital can be saved by using eductors and exhausters rather than rotary airlocks and blowers. However the attention to placement of the sawdust in the center of the fireball, maintaining the position of the fireball, and minimizing the air $/$ fuel ratio $(\mathrm{kg}$ air $/ \mathrm{kg}$ sawdust) to achieve a significant $\mathrm{NO}_{\mathrm{x}}$ reduction favors the use of separate rotary airlocks and blowers.

Capital costs could have been decreased by at least 10 percent if soil conditions at the plants were not poor. In both cases special care had to be given to pilings and sub foundations in order to ensure proper construction.

Process equipment choices abound. Such choices include (not exhaustive)

- Selection of screen type (disc screen, trommel screen, deck screen, wave screen, other)

- Selection of storage systems (silos with internal unloaders, live-bottom bins, other) with the choice impacting capital, operating, and maintenance considerations

- Screening coupled with grinding of oversized particles to reduce the size of the grinder, or grinding of all particles and eliminating the screens (e.g., the system installed at Greenidge Station by NYSEG)

- Mechanical vs pneumatic handling, and various options in mechanical handling (e.g., numerous types of conveyors)

Capital costs, expressed in $\$ / \mathrm{kW}$, will decrease as a function of system capacity; economies of scale hold. Many of the systems purchased were minimum size systems, and this increased the capital cost in $\$ / \mathrm{kW}$.

\subsection{Operations Experiences}

Both the Willow Island and Albright demonstrations showed that cofiring does not have to impact boiler capacity if the system is applied appropriately to the boiler. In both cases capacity implications existed as a function of the induced draft (ID) fans. In both cases there was sufficient fan capacity to support cofiring. 
In the case of separate injection, there is a net benefit associated with cofiring. When wet coal limits capacity — a common winter occurrence for many power plants-separate injection has the benefit of being able to increase the heat input into the primary furnace and recovering capacity. Wet coal capacity limitations typically come as a function of pulverizer performance: feeder speeds for ball mills and mill outlet temperatures for bowl mills. Consequently the boilers have limited ability to introduce the required fuel into the boiler. The separate injection system has the capability of adding fuel to the furnace.

Boiler efficiencies are only modestly impacted by cofiring, and system efficiencies expressed as net station heat rate (NSHR), are impacted to a very minor degree. The NSHR impact at Willow Island was about $3.4 \mathrm{~kJ} / \mathrm{kWh}(3.2 \mathrm{Btu} / \mathrm{kWh})$ for every percent cofiring on a mass basis; at 10 percent cofiring on a mass basis, the impact was 34 $\mathrm{kJ} / \mathrm{kWh}(32 \mathrm{Btu} / \mathrm{kWh})$. The NSHR impact at Albright Generating Station was about 4 $\mathrm{kJ} / \mathrm{kWh}(3.5 \mathrm{Btu} / \mathrm{kWh})$ for every percent cofiring on a mass basis; at 10 percent cofiring on a mass basis, the impact was estimated at about $40 \mathrm{~kJ} / \mathrm{kWh}(35 \mathrm{Btu} / \mathrm{kWh})$.

The efficiency impacts are limited to the moisture in the biomass and the hydrogen in the biomass. There is no necessary impact from dry gas loss, excess $\mathrm{O}_{2}$, or unburned carbon loss. There is no impact from air heater exit temperature when blending sawdust on the coal belt for cyclone firing, however there is about a $5^{\circ} \mathrm{C}\left(8-10^{\circ} \mathrm{F}\right)$ increase in air heater exit temperature with separate injection cofiring in a pulverized coal boiler caused by less combustion air passing through the air heater. Biomass is transported with ambient air.

Operability is not a problem. In the cyclone boiler it was difficult for the operators to know when cofiring was occurring and when it was not. In the T-fired boiler the operator had specific control over the flow of sawdust. Cofiring could occur over a wide range of loads without impacting flame stability or other operating conditions.

Operational advantages for the cyclone boiler included maintaining cyclone temperatures while decreasing FEGT. At the same time, the FEGT decrease did not cause a decrease in main steam or reheat steam temperatures. Deposition of inorganic constituents in slagging and fouling regions was somewhat facilitated by cofiring. Further, the composition of the biomass and opportunity fuel meant that the boiler could tolerate coals with somewhat lower volatility, and the ash characteristics had a favorable impact on $T_{250}$ temperatures.

\subsection{Emissions Results}

Emissions were improved for both Willow Island and Albright Generating Stations. Between the two units, some 10,000 tons of sawdust were burned. This equated to 11,000 tons of fossil $\mathrm{CO}_{2}$ directly reduced by the demonstrations, and the equivalent of 33,000 tons of fossil $\mathrm{CO}_{2}$ reduced when all factors were included. $\mathrm{SO}_{2}$ was reduced, consistent with the fuel characteristics. Mercury emissions also were reduced consistent with the fuel characteristics. 
The testing at Albright Generating Station demonstrated that cofiring has no impact on $\mathrm{CO}$ emissions or opacity emissions. Those results also occurred at Willow Island Generating Station.

$\mathrm{NO}_{\mathrm{x}}$ emissions were reduced at the Albright Generating Station, but not at the Willow Island Generating Station. Several factors contributed to the $\mathrm{NO}_{\mathrm{x}}$ reductions at Albright Generating Station including the following:

- Introduction of a nitrogen-free, highly volatile biomass fuel into the center of the fireball in a substoichiometric regime, to scavenge $\mathrm{NO}_{\mathrm{x}}$ formed during the combustion process

- Permitting the use of more SOFA to cause deeper staged combustion without incurring a penalty associated with unburned carbon in the flyash

- Reducing the load on the pulverizers, thereby permitting a finer grind of the coal

The lack of NOx reduction in the Willow Island boiler can be attributed to the fact that the current operation of the unit includes significant staging in the cyclone barrel, and such staging was the common mechanism promoted by cofiring at Bailly Generating Station, Michigan City Generating Station, and the Allen Fossil Plant.

\subsection{Conclusions}

The technical benefits of biomass cofiring, along with the modest penalties, provide a basis for evaluating this family of technologies. Certainly the Willow Island and Albright demonstrations proved that cofiring can be commercially deployed in cyclone and T-fired pulverized coal boilers. To extend that concept to wall-fired boilers, particularly with separate injection, remains to be proven.

Whether cofiring is deployed or not depends entirely upon the availability and cost of sawdust or other forms of biomass within economic reach of a given plant. In such an evaluation the $\mathrm{SO}_{2}$ and $\mathrm{NO}_{\mathrm{x}}$ credits need to be monetized given the specific conditions of a given utility. This includes both the price of such credits and the emissions management strategy of that utility. Further, should $\mathrm{CO}_{2}$ credits achieve values greater than $\$ 1$ - $\$ 2 /$ tonne of $\mathrm{CO}_{2}$, then these values merit addition to the equation.

The Allegheny Energy Supply Co., LLC cofiring demonstrations must be considered highly successful. They brought two cofiring technologies to the point of commercialization, addressed capital cost and operating issues, and documented the environmental consequences of such practices. 


\section{References and Bibliography (including all papers published regarding the Allegheny Cofiring Demonstrations)}

Battista, J., E. Hughes, and D. Tillman. 2000. Biomass Cofiring at Seward Station. Biomass and Bioenergy. 19(6):419-428.

Baxter, L.L. et. al. 1996. Nitrogen Release During Coal Combustion. Energy \& Fuels. 10(1): 188-196.

*Holt, G. 2003. Alternate Fuels. Presented at the Community Advisory Panel Meeting, Pleasants/Willow Island District, West Virginia. July 7.

*Johnson, D., D. Tillman, and B. Miller. 2003. Reactivity of Selected Opportunity Fuels: Measurements and Implications. Proc. Electric Power Conference. Houston, TX. Mar. 3 - 5.

*Johnson, D., D. Tillman, B. Miller, D. Clifford, and S. Pisupati. 2001. Characterizing Biomass Fuels for Cofiring Applications. Proc. Joint International Combustion Symposium. American Flame Research Committee. Kaui, Hawaii. Sep 9 - 12.

*Payette, K., T. Banfield, T. Nutter, and D. Tillman. 2002. Emissions Management at Albright Generating Station Through Biomass Cofiring. Proc. $27^{\text {th }}$ International Technical Conference on Coal Utilization and Fuel Systems. Coal Technology Association. Clearwater, FL. March 4 - 7.

Shafizadeh, F. and W. DeGroot. 1977. Thermal Analysis of Forest Fuels. in Fuels and Energy from Renewable Resources. Academic Press, New York. pp. 93-114.

Tillman, D.A. and N.S. Harding. 2004. Fuels of Opportunity: Characteristics and Uses in Combustion Systems. Elsevier. London, UK.

*Tillman, D., K. Payette, and T. Banfield. 2003. Cofiring Biomass at Allegheny Energy: Conclusions of an Extended Demonstration Program. Proc. $20^{\text {th }}$ Pittsburgh Coal Conference. Pittsburgh, PA. Sep $15-19$.

*Tillman, D., D. Johnson, and B. Miller. 2003. Analyzing Opportunity Fuels for Firing in CoalFired Boilers. Proc. $28^{\text {th }}$ International Technical Conference on Coal Utilization and Fuel Systems. Coal Technology Association. Clearwater, FL. March $9-13$.

*Tillman, D. 2003. Cofiring Biomass with Coal at Allegheny Energy. Proc. Electric Power Conference. Houston, TX. March 3 - 5.

*Tillman, D., B. Miller, and D. Johnson. 2002. Nitrogen Evolution from Biomass Fuels and Selected Coals. Proc. $19^{\mathrm{h}}$ Pittsburgh Coal Conference. Pittsburgh, PA. Sep $23-26$. 
*Tillman, D., K. Payette, T. Banfield, and G. Holt. 2002. Firing Sawdust and TireDerived Fuel with Coal at Willow Island Generating Station. Proc. $27^{\text {th }}$ International Technical Conference on Coal Utilization and Fuel Systems. Coal Technology Association. Clearwater, FL. March 4 - 7.

Tillman, D. A. 2002. Cofiring Technology Review. National Energy Technology Laboratory, US Department of Energy. Pittsburgh, PA.

*Tillman, D. and K. Payette. 2001. Developing a Designer Opportunity Fuel System for Willow Island Generating Station. Proc. $26^{\text {th }}$ International Technical Conference on Coal Utilization and Fuel Systems. Coal Technology Association. Clearwater, FL. March $5-8$.

Tillman, D. A. 2001. Final Report: EPRI-USDOE Cooperative Agreement: Cofiring Biomass with Coal. EPRI. Palo Alto, CA. Report 1004601.

*Tillman, D., K. Payette, and J. Battista. 2000. Designer Opportunity Fuels for the Willow Island Generating Station of Allegheny Energy Supply Company, LLC. Proc. $17^{\text {th }}$ Pittsburgh Coal Conference. Pittsburgh, PA. Sep $11-14$.

Tillman, D. 2000. Biomass Cofiring: the Technology, the Experience, the Combustion Consequences. Biomass and Bioenergy. 19(6):365-384.

Tillman, D.A. 1999. Biomass Cofiring: Field Test Results. EPRI, Palo Alto, CA. Report TR 113903.

Tillman, D. A. et. al. 1997. Wood Cofiring in a Cyclone Boiler at TVA's Allen Fossil Plant. EPRI. Palo Alto, CA. Report TR-109378

Tillman, D.A. et. al. 1996a. Cofiring Alternate Fuels in Coal-Fired Cyclone Boilers. Proc. American Flame Research Committee 1996 International Symposium: Combustion in Industry - Status and Needs into the $21^{\text {st }}$ Century. Baltimore, MD. Sep $30-$ Oct 2.

Tillman, D.A. et. al. 1996b. Fuel Blending and Switching for NOx Control Using Biofuels with Coal in Cyclone Boilers. Proc. Biomass Usage for Utility and Industrial Power. Engineering Foundation Conference. Snowbird, UT. April 28 - May 3.

*Indicates publication derived directly from the Allegheny demonstrations. 